LBNL-45406

\title{
Feasibility of an Appliance Energy Testing and Labeling Program for Sri Lanka
}

\author{
FINAL REPORT
}

Peter Biermayer, John Busch, Sajid Hakim, Issac Turiel
Lawrence Berkeley National Laboratory

Peter du Pont

International Institute for Energy Conservation

Chris Stone

Intertek Testing Services

\section{April 2000}

Prepared for:

DSM Branch, Ceylon Electricity Board 


\section{Table of Contents}

Task 2 Identify Appliances with Significant Energy Savings in Sri Lanka .......... 2-1

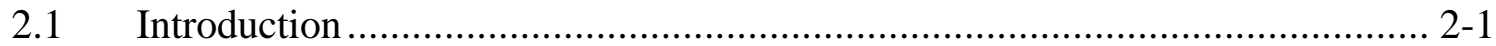

2.2 Saturation of End-Use Appliances in Sri Lanka ......................................... 2-2

2.3 Appliance Usage and Their Electricity Consumption ..................................... 2-4

2.4 Sri Lanka Household Electricity Consumption............................................. 2-8

$2.5 \quad$ Potential for Electricity Savings .................................................................

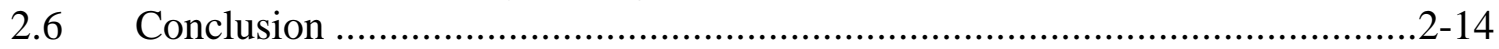

Task 3 Summarize the Anticipated Benefits and Costs From the Establishment of a Testing Facility ....................................................................................... 3-1

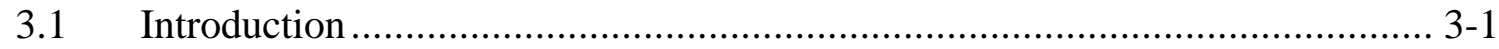

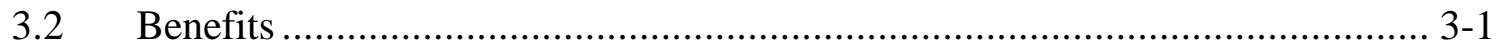

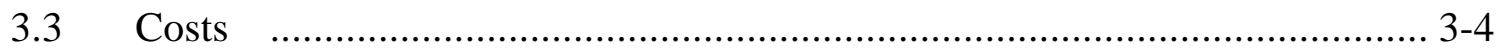

Task 4 Organizational Structure .............................................................................. 4-1

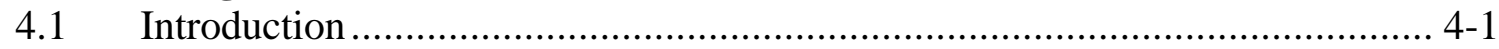

4.2 Organizational Survey …………....................................................... 4-1

4.3 Organizational Skills ………....................................................... 4-4

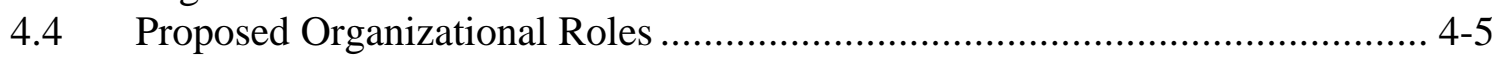

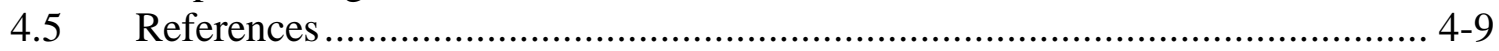

4.6 Appendix A: Notes from Meetings with Stakeholder Organizations................4-10

4.7 Appendix B: Members of Appliance Energy Labeling Steering Committee ...4-15

Task 5 Action Plan: Energy Testing and Labeling Regime...................................... 5-1

$5.1 \quad$ Introduction .......................................................................................... 5-1

5.2 Step 1: Formalize the Appliance Testing and Labeling Program ..................... 5-1

$5.3 \quad$ Step 2: Develop Testing Capability ……………..................................... 5-2

5.4 Step 3: Implement a Pilot Voluntary Labeling Program .................................. 5-4

5.5 Step 4: Enact Legislation to Support Mandatory Labeling and Standards ........ 5-5

5.6 Step 5: Implement a Labeling Program …………...................................... 5-7

5.7 Step 6: Implement Minimum Efficiency Standards .....................................5-10

5.8 Step 7: Monitor and Evaluate the Program................................................5-10

5.9 Step 8: Revise and Update Labels and Standards ......................................5-12

5.10 Estimated Program Costs.......................................................................

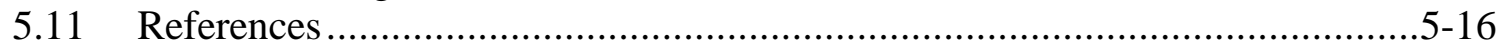

5.12 Appendix A: Memo on Draft Standard for Ballast Labeling Program..............5-17

5.12 Appendix A: Implementation Plan ................................................................5-19

Task 6 Appliances and Lighting Test Procedures and Instrumentation............... 6-1

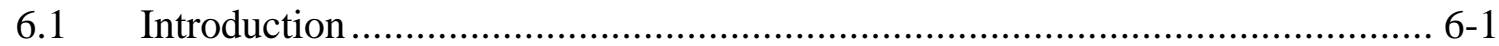

6.2 Lighting - Ballasts .............................................................................. 6-5

6.3 Lighting - Compact Fluorescent Lamps (CFLs) ...........................................6-15

6.4 Household Refrigerators ...........................................................................6-19 
6.5 Room Air Conditioners................................................................. $6-26$

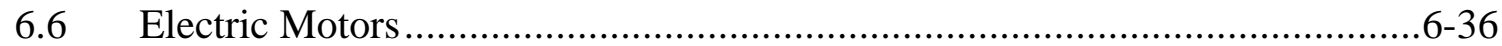

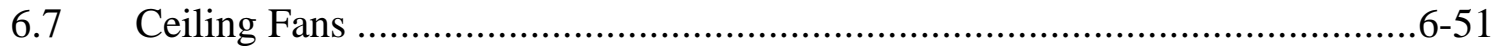

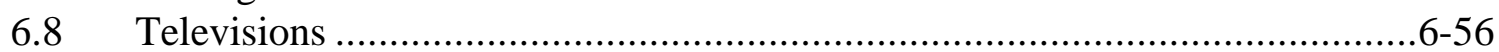

6.9 Pumps ......................................................................................6-59

6.10 Sources of Information - Equipment Suppliers - Test Standards - Accreditation ..

$7 \quad$ Recommendations............................................................................ 7-1 


\section{List of Tables}

Table 2.1 Residential Electricity Tariffs in Sri Lanka ......................................... 2-2

Table 2.2 Saturation of Electricity Using Appliances in Urban Sri Lanka ................. 2-3

Table 2.3 Lighting in Urban Sri Lanka ............................................................ 2-4

Table 2.4 Refrigerator Saturations by Type of Unit in Urban Sri Lanka................... 2-5

Table 2.5 Fan Use in Urban Sri Lanka................................................................. 2-5

Table 2.6 Electricity Consumption for Televisions in Urban Sri Lanka..................... 2-6

Table 2.7 Appliance Saturation and Usage in Urban Sri Lanka ............................. 2-8

Table 2.8 End-Use Data and Electricity Consumption in Sri Lanka Urban

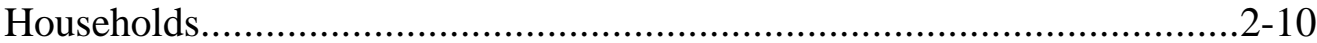

Table 2.9 Impact of Higher Efficiency Appliances on Urban Sri Lanka Residential Electricity Consumption ........................................................2-14

Table 3.1 Life Cycle Cost Savings for Selected Appliances in Sri Lanka................. 3-2

Table 3.2 Emission Factors and Emission Reductions from Efficiency Standards: Coal-fired Power Plants........................................................................... 3-4

Table 3.3 Summary of Estimated Benefits And Costs to Nation From Test Facility... 3-5

Table 4.1 Skills Matrix for Sri Lanka Stakeholders............................................. 4-5

Table 4.2 Proposed Organizational Responsibilities ........................................... 4-6

Table 5.1 Comparison of Label Types from around the World.............................. 5-9

Table 5.2 Cost Budget for the Labeling Program Office .....................................5-13

Table 5.3 Budget for Consulting Assistance to Sri Lanka Appliance Testing and Labeling

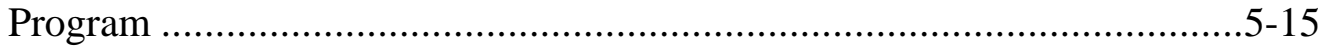

Table 6.1 Test Laboratory Cost Summary................................................... 6-1

Table 6.2 Ballast Test Procedure Standards .................................................... 6-5

Table 6.3 U.S. DOE's Ballast Test Procedure Requirements ................................. 6-7

Table 6.4 Ballast Testing Instrumentation and Equipment ...................................... 6-8

Table 6.5 Ballast Test Procedure Standards .......................................................6-12

Table 6.6 Typical Instrumentation for Flourescent Lamps ...................................6-16

Table 6.7 APEC Test Procedure Standards for Lighting ....................................6-17

Table 6.8 Test Procedures for Household Refrigerators ......................................6-19

Table 6.9 ISO 7371 - Household Refrigerators ...............................................6-20

Table 6.10 Refrigerator and Freezer Test Facility Instrument List ..........................6-21

Table 6.11 Room Air Conditioning Test Procedures..............................................6-26

Table 6.12 Test Procedures for Room Air Conditioners -- ISO 5151 .....................6-27

Table 6.13 Calibrated Calorimeter Room Instrument List .................................6-28

Table 6.14 Motor Test Facility Cost - Thailand................................................6-39

Table 6.15 Instrumentation Accuracy of Efficiency Testing Standards for Electric

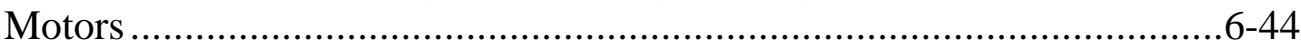

Table 6.16 Ceiling Fan Test Procedure Standards............................................6-51 
Table 6.17 Sri Lanka \& CSA Test Procedure Requirements for Ceiling Fans .........6-52

Table 6.18 Instruments \& Equipment for Testing Ceiling Fans .............................6-53

Table 6.19 Television Test Procedure Standards................................................6-56

Table 6.20 U.S. DOE Test Procedure Instrumentation - Televisions .......................6-57

Table 6.21 JIS Test Procedure Requirements - Televisions ..................................6-57

Table 6.22 Equipment based on U.S. DOE Television Standard ...........................6-57

Table 6.23 Equipment Requirements ........................................................6-60

Table 7.1 Costs for Four Lab Program............................................................ 7-1

Table 7.2 Costs for Six Lab Program............................................................... 7-2 


\section{List of Figures}

Figure 2.1 Major Contributors to Household Energy Consumption in Urban Sri Lanka

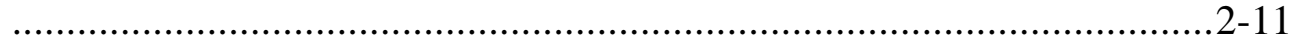

Figure 4.1 Schematic of the Appliance Testing and Labeling Program .....................4-6 


\section{Task 2 - IDENTIFY APPLIANCES WITH SIGNIFICANT ENERGY SAVINGS POTENTIAL IN SRI LANKA}

\subsection{INTRODUCTION}

In order to identify opportunities for electricity savings in Sri Lanka, it is necessary to analyze the end-uses of electrical energy. The first step is to estimate total national energy use by each major appliance type (e.g., refrigerators and lighting). Several parameters must be determined to estimate national energy use. They are saturations (percent of households with each appliance type), UECs (unit energy consumption), and number of households. Total national electricity use is calculated by using the following equation for each appliance type and then summing for all electrical appliances.

National electricity use $=$ [Urban Saturation $\times$ UEC $($ Urban $) \times \#$ Urban Households] $+[$ Rural Saturation $\times$ UEC (Rural) $\times \#$ Rural Households $]$

Ideally, one wants to know saturations and UECs for both urban and rural households.

We have utilized data collected by SRC from their "Residential Sector Electricity Use Survey". ${ }^{1}$ This survey of 1713 urban households collected data on typical use of electrical appliances. It was carried out in 1999. Saturations, or the percentage of households with a particular appliance, were obtained directly from the survey. For some appliances enough data were collected to estimate unit energy consumption (UEC), or annual energy use in kWh/yr. For example for lighting, the number of light bulbs, their wattages and hours of use are all provided, allowing for estimation of lighting energy use. In other cases, for example refrigerators, there are not enough data to directly estimate UEC; therefore, we had to utilize data from other countries for similar products.

The annual electricity consumption based upon the usage data obtained from the SRC survey was found to be lower by $18 \mathrm{kWh} / \mathrm{y}$ than the electricity consumption of $1839 \mathrm{kWh}$ per year calculated based on monthly bills. The average monthly electricity bill of the survey respondents was Rs 613 and based on electricity tariffs listed in table 2.1, the monthly electricity consumption amounts to $153.3 \mathrm{kWh}$ or $1839 \mathrm{kWh} / \mathrm{y}$ per house. However, annual energy use based on usage data does not include electricity consumed by some of the appliances for which we did not have enough data to include them in the total. These appliances are likely to use more than $18 \mathrm{kWh} / \mathrm{y}$. Once these end-uses are included in the total, it is likely that the total obtained from usage data will be higher than that obtained from the bill information. Examples of such appliances include immersion heaters, electric stove, electric hot plates, electric kettles, grinder/blenders, geysers, fax machines, and personal computers. Most of these appliances with the exception of immersion heaters and electric water pumps have low saturation levels. . In addition to not including some of the end-uses listed, the difference in the per household electricity consumption between that calculated from the bill and that estimated from usage data 
may be due to any number of reasons including uncertainty in the usage estimates, efficiency data, saturation assumptions, errors in bills, or fluctuations in monthly bills. For this analysis, we have assumed the average household electricity consumption calculated on the basis of monthly bills to be a better measure and attributed the difference between this and the total obtained from usage information to "other" end-uses for which we did not have sufficient data to make a direct estimate.

Table 2.1 Residential Electricity Tariffs in Sri Lanka

\begin{tabular}{|l|l|}
\hline Electricity Used & Rate (Rs per unit) \\
\hline \hline First 30 units & 2.20 (monthly minimum of Rs 25.00) \\
\hline $31-90$ units & 2.60 \\
\hline $91-180$ units & 5.00 \\
\hline Above 180 units & 6.60 \\
\hline
\end{tabular}

\section{Number of Households in Sri Lanka}

The number of households and the proportion of urban to rural households in Sri Lanka were derived indirectly ${ }^{\mathrm{a}}$ from information available from Economic and Social Statistics of Sri Lanka. ${ }^{2}$ According to Economic and Social Statistics of Sri Lanka, 23\% of Sri Lankan population is urban and the remaining $77 \%$ is rural. According to page 99 of the same publication, saturation of televisions is $50.6 \%$ and page 116 lists the number of televisions at 1.7 million. The number of urban households is derived as follows:

Total number of households (urban + rural $)=1700000 / 0.506=3.36$ million

Number of urban households $=3.36 \times 0.23=776$ thousand

Number of rural households $=3.36 * 0.77=2.6$ million

This calculation assumes the same number of people per household for rural and urban households. The number of households derived is for the year 1997.

\subsection{SATURATION OF END-USE APPLIANCES IN SRI LANKA}

Table 2.2 lists the saturation of appliances in Sri Lanka based on the survey results. It was not possible to determine whether the survey represented urban or rural households but due to the

${ }^{a}$ The number of households could also be derived from the number of members per household information. However, this information was not available to LBNL until after most of analysis had been completed. 
relatively high level of saturations of large appliances like refrigerators, we have assumed that the survey represents only the urban households of Sri Lanka.

Table 2.2 Saturation of Electricity Using Appliances in Urban Sri Lanka

\begin{tabular}{|c|c|c|c|}
\hline End-Use & Saturation & End-Use & Saturation \\
\hline Elec Stove & $0.9 \%$ & Personal Computer & $3.5 \%$ \\
\hline Elec Hot Plate & $5.4 \%$ & Fax Machine & $0.9 \%$ \\
\hline Rice Cooker & $32.5 \%$ & Fans & $79.3 \%$ \\
\hline Electric Oven & $18.7 \%$ & Pedestal & $29.8 \%$ \\
\hline Microwave & $2.8 \%$ & Table & $36.7 \%$ \\
\hline Electric Kettle & $15.4 \%$ & Ceiling & $50.3 \%$ \\
\hline Grinder/Blender & $53.7 \%$ & $\mathrm{TV}$ & $93.5 \%$ \\
\hline Gyser & $3.0 \%$ & Color TV & $84.6 \%$ \\
\hline Washing Machine & $22.2 \%$ & $\mathrm{~B} / \mathrm{W} \mathrm{TV}$ & $13.3 \%$ \\
\hline Clothes Dryer & $1.2 \%$ & Video Recorder/Laser Disk & $27.7 \%$ \\
\hline Vacuum Cleaner & $10.3 \%$ & Stereo & $85.3 \%$ \\
\hline Immersion Heater & $32.3 \%$ & Toaster & $26.8 \%$ \\
\hline Electric Water Pump & $18.3 \%$ & Iron & $94.9 \%$ \\
\hline Lighting & & Hair Dryer & $3.4 \%$ \\
\hline Incandescent & $98.5 \%$ & $\mathrm{~A} / \mathrm{C}$ & $2.1 \%$ \\
\hline Compact Fluorescent & $23.1 \%$ & Refrigerator & $71.9 \%$ \\
\hline Fluorescent $4 \mathrm{ft}$ tubes & $64.2 \%$ & 1-Door & $50.4 \%$ \\
\hline Flourescent $2 \mathrm{ft}$ tubes & $29.1 \%$ & 2-3 Door & $39.7 \%$ \\
\hline Flourescent Circular & $7.9 \%$ & Frost Free & $8.3 \%$ \\
\hline Incandescent Spotlights & $1.0 \%$ & Freezer & $1.8 \%$ \\
\hline Incandescent Reflectors & $0.5 \%$ & Other & $0.6 \%$ \\
\hline Halogen Lamps & $0.5 \%$ & & \\
\hline
\end{tabular}




\subsection{APPLIANCE USAGE AND THEIR ELECTRICITY CONSUMPTION}

\section{Lighting}

Lighting in Sri Lanka is predominantly incandescent with $4 \mathrm{ft}$ fluorescent tubes being the second most common type of lighting. Two foot fluorescent tubes and compact fluorescents are the next most common type of lighting. Table 2.3 shows the saturation of different kinds of lighting in urban households in Sri Lanka along with the average watts, hours of operation, and number of lamps per household. The survey does not provide any information on ballasts used to drive the fluorescent lamps. Assuming an average ballast uses $10 \mathrm{~W}$, electricity consumption due to ballasts can be calculated as follows:

Ballast Energy Consumption $=$ Saturation $\mathrm{x}$ Fluorescent lamps per household $\mathrm{x}$ No. of hrs used $\mathrm{x} 10 \mathrm{~W}$ and comes out to be $31 \mathrm{kWh} /$ year.

Table 2.3 Lighting in Urban Sri Lanka

\begin{tabular}{|l|c|l|l|l|c|}
\hline Type & Saturation & $\begin{array}{l}\text { Avg. } \\
\text { No./house }\end{array}$ & $\begin{array}{l}\text { Avg. } \\
\text { hrs/day* }\end{array}$ & $\begin{array}{l}\text { Avg. } \\
\text { Watts/lamp }\end{array}$ & $\begin{array}{l}\text { Energy } \\
\text { Use/house } \\
\text { (kWh/yr) }\end{array}$ \\
\hline \hline Incandescent & $98.5 \%$ & 9.0 & 27.2 & 58.4 & 569 \\
\hline Fluorescent 4ft Tubes & $64.2 \%$ & 2.3 & 7.0 & 39.0 & 64 \\
\hline Fluorescent 2ft Tubes & $29.1 \%$ & 1.4 & 5.9 & 21.6 & 13 \\
\hline Compact Fluorescent & $23.1 \%$ & 1.5 & 8.0 & 18.4 & 12 \\
\hline Fluorescent Circular & $7.9 \%$ & 1.4 & 6.0 & 26.1 & 5 \\
\hline Total & & & & & 663 \\
\hline
\end{tabular}

* This represents the sum total of hours of operation per day for all lamps of the same type and hence can be greater than $24 \mathrm{hrs} / \mathrm{day}$

In addition, the survey showed saturation of $1 \%$ for incandescent spotlights, $0.5 \%$ for incandescent reflectors, and $0.5 \%$ for halogen lamps. The electricity usage from lighting amounts to $663 \mathrm{kWh} / \mathrm{y}$ per house.

\section{Refrigerators}

The survey shows a $72 \%$ saturation for refrigerators in urban Sri Lanka. Table 2.4 shows the break-down of refrigerator types. 
Table 2.4 Refrigerator Saturations by Type of Unit in Urban Sri Lanka

\begin{tabular}{|l|c|c|c|c|}
\hline $\begin{array}{l}\text { Refrigerator } \\
\text { Type }\end{array}$ & Fraction of Total & Less than 3 ft tall & $\mathbf{3}$ to 5 ft tall & Over 5 ft tall \\
\hline \hline 1 Door & $50.4 \%$ & $27.7 \%$ & $54.6 \%$ & $17.5 \%$ \\
\hline $2-3$ Door & $39.7 \%$ & $2.0 \%$ & $54.0 \%$ & $44.0 \%$ \\
\hline Frost Free & $8.3 \%$ & $1.9 \%$ & $25.0 \%$ & $73.1 \%$ \\
\hline Freezer & $1.8 \%$ & $21.7 \%$ & $52.2 \%$ & $26.1 \%$ \\
\hline Other & $0.6 \%$ & $0.0 \%$ & $0.0 \%$ & $100.0 \%$ \\
\hline
\end{tabular}

The survey does not provide the energy consumption of these refrigerators and hence we had to estimate the energy-use from other sources. We learned that Thailand is a major exporter of refrigerators to Sri Lanka so we have assumed that the average energy consumption of refrigerators in Sri Lanka equals the average energy consumed by new refrigerators in Thailand that are rated No.3 according to the Thailand refrigerator labeling scheme. This amounts to a unit energy consumption of $468 \mathrm{kWh} / \mathrm{y}^{3}$

Using Equation 1, this results in an average electricity consumption of $336 \mathrm{kWh} / \mathrm{y}$ per household.

\section{Fans}

In urban Sri Lanka $79 \%$ of the households have at least one fan. Table 2.5 presents the saturation along with power, usage, and number of fans per household. The survey does not provide the average watts per fan and this has been estimated based upon Chinese efficiency standards data from APEC Workshop on Setting-up and Running Energy Performance Laboratories ${ }^{4}$.

Table 2.5 Fan Use in Urban Sri Lanka

\begin{tabular}{|l|c|c|c|c|c|}
\hline $\begin{array}{l}\text { Fan } \\
\text { Type }\end{array}$ & Saturation & $\begin{array}{c}\text { Avg. } \\
\text { No./house }\end{array}$ & Avg. hrs/day & $\begin{array}{c}\text { Avg. } \\
\text { Watts/fan }\end{array}$ & $\begin{array}{c}\text { Energy Use/house } \\
\text { (kWh/y) }\end{array}$ \\
\hline \hline Pedestal & $29.8 \%$ & 1.28 & 8.64 & 59 & 55 \\
\hline Table & $36.7 \%$ & 1.23 & 7.96 & 42 & 45 \\
\hline Ceiling & $50.3 \%$ & 2.37 & 12.25 & 72 & 162 \\
\hline Total & & & & & 262 \\
\hline
\end{tabular}




\section{Televisions}

The urban saturation for televisions in Sri Lanka is $93.5 \%$ with $84.6 \%$ of households with a color television and $13.3 \%$ of households with a black and white television. The survey does not provide the average watts per television and this has been estimated from wattage measurement data for 19/20 inch screen televisions in the U.S. Color televisions also have stand-by losses attributed to the remote control unit. These were measured to be 5.1 Watts in a study performed at LBNL. ${ }^{5}$ This amounts to an annual electricity consumption of $157 \mathrm{kWh} / \mathrm{y}$ for televisions in urban Sri Lanka. Table 1.6 breaks down the electricity usage by color and black and white units. Energy consumption is calculated as: Energy Use $=$ Standby Watts x $8760+$ Active Watts x Avg. Hrs/day x 365

Table 2.6 Electricity Consumption for Televisions in Urban Sri Lanka

\begin{tabular}{|l|c|c|c|c|c|}
\hline TV Type & Saturation & $\begin{array}{c}\text { Avg. } \\
\text { hrs/day }\end{array}$ & $\begin{array}{c}\text { Avg. Standby } \\
\text { Loss (Watts) }\end{array}$ & $\begin{array}{c}\text { Avg. Active } \\
\text { Watts }^{7}\end{array}$ & $\begin{array}{c}\text { Energy } \\
\text { Use/house } \\
\text { (kWh/y) }\end{array}$ \\
\hline \hline Color & $84.6 \%$ & 5.4 & 5.1 & 68 & 151 \\
\hline Black \& White & $13.3 \%$ & 5.1 & 0.0 & 23 & 6 \\
\hline Total & & & & & 157 \\
\hline
\end{tabular}

\section{Electric Pumps}

According to the SRC survey, electric water pumps in urban Sri Lanka have a saturation of $18.3 \%$. The survey does not provide any information on size, type or usage of these pumps and therefore we have not analyzed pumps in this report. However, water pumping is an energyintensive application and would result in significant energy consumption.

\section{Electric Motors}

According to Meyers, Monahan, Lewis, Greenberg and Nadel ${ }^{8}$ electric motor systems consume some $65-80 \%$ of industrial electricity in developing countries. "Electric Motor Systems" include the electric motor as well as the power transmission equipment (belts, gears, etc.) and the driven equipment (pumps, compressors, etc.). For example, $74 \%$ of the industrial electricity consumed in India can be attributed to motor systems. Further, electric motors are also an integral part of many of the residential and commercial-use appliances and major contributors to their energy consumption. However, LBNL was unable to obtain any data on number of motors or their efficiency in Sri Lanka and therefore we have not analyzed electric motors.

\section{Air conditioners}

Air conditioner saturation in Sri Lanka is still low with only $2.1 \%$ of the urban households possessing air conditioning units. In this analysis, due to lack of survey data, we have assumed a $18,000 \mathrm{Btu} / \mathrm{hr}$ capacity unit with a $7.4 \mathrm{EER}$, running 787 hours a year. These assumptions are based on a study done air conditioner energy consumption in Thailand.' 
Energy Use $=$ Saturation $\mathrm{x}($ Capacity/EER $) \times$ Hrs/year

Energy Use $=2.1 \%$ x $(18000 / 7.4) \times 787=40231$ Watt-hrs $/ y r=40.2 \mathrm{kWh} / \mathrm{y}$

\section{Other End-Uses}

Table 2.7 provides the saturation and usage results from the SRC survey for some other household appliances in Sri Lanka not analyzed in this study due to lack of data. 
Table 2.7 Appliance Saturation and Usage in Urban Sri Lanka

\begin{tabular}{|l|l|l|}
\hline Appliance & Saturation & Average Usage (Hrs/day) \\
\hline \hline Rice Cookers & $32.5 \%$ & 0.61 \\
\hline Electric Oven & $18.7 \%$ & 0.73 \\
\hline Electric Stove & $0.9 \%$ & Not Available \\
\hline Electric Hot Plate & 5.45 & Not Available \\
\hline Microwave & $2.8 \%$ & Not Available \\
\hline Electric Kettle & $15.4 \%$ & Not Available \\
\hline Grinder/Blender & $53.7 \%$ & Not Available \\
\hline Washing Machine & $22.2 \%$ & Not Available \\
\hline Clothes Dryer & $1.2 \%$ & Not Available \\
\hline Vacuum Cleaner & $10.3 \%$ & Not Available \\
\hline Immersion Heater & $32.3 \%$ & Not Available \\
\hline Electric Water Pump & $18.3 \%$ & Not Available \\
\hline Personal Computer & $3.5 \%$ & Not Available \\
\hline Fax Machine & $0.9 \%$ & Not Available \\
\hline Video Recorder & $27.7 \%$ & 1.5 \\
\hline Stereo & $85.3 \%$ & 3.5 \\
\hline Toaster & $26.8 \%$ & 0.76 \\
\hline Iron & $94.9 \%$ & 0.76 \\
\hline Air Conditioner & $2.1 \%$ & Not Available \\
\hline Hair Dryer & $3.4 \%$ & 1.13 \\
\hline Geyser & $3.0 \%$ & Not Available \\
\hline Other & $0.6 \%$ & Not Available \\
\hline
\end{tabular}

\subsection{SRI LANKA HOUSEHOLD ELECTRICITY CONSUMPTION}

Based on the information gathered from the survey and LBNL's estimates, Table 2.8 summarizes the end-uses for electricity in Sri Lankan households. In order to calculate the electricity 
consumption of each appliance at the national level, urban households were assumed to total 776 thousand. Equation 1 is used to calculate the Household Energy Use in $\mathrm{kWh} / \mathrm{y}$. According to the Economic and Social Statistics of Sri Lanka, the total residential sector electricity sales in 1997 were $1213 \mathrm{GWh}$. Assuming a 10\% annual increase in 1998 and 1999, residential electricity sales should be $1468 \mathrm{GWh}$ in 1999. Assuming average household electricity consumption of 1839 $\mathrm{kWh} / \mathrm{y}$ (as obtained from the survey information and electricity tariffs data) and 776 thousand urban households, the electricity consumed by the urban sector of Sri Lanka amounts to 1427 Gwh or $97 \%$ of the total residential electricity consumption. This is unlikely to be true as the rural sector comprises $77 \%$ of the Sri Lankan population and consists of 1.1 million electrified households (assuming 44\% rural electrification). Perhaps the households surveyed in the SRC survey are not representative of typical urban households in Sri Lanka resulting in a very high estimate of household electricity consumption. 
Table 2.8 End-Use Data and Electricity Consumption in Sri Lanka Urban Households

\begin{tabular}{|c|c|c|c|c|c|c|}
\hline \multicolumn{3}{|c|}{$\begin{array}{c}\text { Urban Households }(000) \\
\text { Average Electricity per house }(\mathrm{kWh})\end{array}$} & \multicolumn{2}{|l|}{$\begin{array}{c}776 \\
1839\end{array}$} & \multirow[b]{2}{*}{$\begin{array}{c}\text { Household } \\
\text { Energy } \\
\text { Use } \\
(\mathrm{kWh} / \mathrm{y}) \\
\end{array}$} & \multirow[b]{2}{*}{$\begin{array}{c}\text { Sri-Lanka } \\
\text { National } \\
\text { Energy Use } \\
(\mathrm{GWh} / \mathrm{y})\end{array}$} \\
\hline End Use & Saturations & $\begin{array}{l}\text { Avg.Use } \\
\text { (hrs/day) }\end{array}$ & $\begin{array}{l}\text { Daily Energy } \\
\text { Use }(\mathrm{kWh} / \mathrm{d}) \\
\end{array}$ & $\begin{array}{c}\text { Number } \\
\text { per House }\end{array}$ & & \\
\hline Rice Cooker ${ }^{1}$ & $33 \%$ & 0.61 & 0.27 & Not Available & 32 & 25 \\
\hline Electric Oven ${ }^{2}$ & $19 \%$ & 0.73 & 0.61 & Not Available & 42 & 33 \\
\hline Microwave $^{2}$ & $3 \%$ & Not Available & 0.17 & Not Available & 2 & 1 \\
\hline Washing Machine ${ }^{2}$ & $22 \%$ & Not Available & 0.68 & Not Available & 55 & 43 \\
\hline Clothes Dryer ${ }^{2}$ & $1 \%$ & Not Available & 1.13 & Not Available & 5 & 4 \\
\hline Vacuum Cleaner $^{2}$ & $10 \%$ & Not Available & 0.05 & Not Available & 2 & 1 \\
\hline Lighting $^{3}$ & & & & & & \\
\hline Incandescent & $98 \%$ & 27.15 & 1.58 & 9.02 & 569 & 442 \\
\hline Compact Fluorescent & $23 \%$ & 7.99 & 0.15 & 1.53 & 12 & 10 \\
\hline Fluor $4 \mathrm{ft}$ tubes & $64 \%$ & 7 & 0.27 & 2.3 & 64 & 50 \\
\hline Flourescent $2 \mathrm{ft}$ tubes & $29 \%$ & 5.86 & 0.13 & 1.4 & 13 & 10 \\
\hline Flourescent circular & $8 \%$ & 6 & 0.16 & 1.4 & 5 & 4 \\
\hline Fans $^{4}$ & $79 \%$ & & & & & \\
\hline Pedestal & $30 \%$ & 8.64 & 0.51 & 1.28 & 56 & 43 \\
\hline Table & $37 \%$ & 7.96 & 0.33 & 1.23 & 45 & 35 \\
\hline Ceiling & $50 \%$ & 12.25 & 0.88 & 2.37 & 162 & 126 \\
\hline $\mathrm{TV}^{1}$ & $93 \%$ & & & & & \\
\hline Color TV & $85 \%$ & 5.4 & 0.49 & 1 & 151 & 117 \\
\hline $\mathrm{B} / \mathrm{W} \mathrm{TV}$ & $13 \%$ & 5.08 & 0.12 & 1.02 & 6 & 4 \\
\hline Video Recorder/Laser Disk ${ }^{1}$ & $28 \%$ & 1.5 & 0.02 & 1.02 & 2 & 2 \\
\hline Toaster $^{1}$ & $27 \%$ & 0.76 & 0.61 & Not Available & 59 & 46 \\
\hline Iron $^{1}$ & $95 \%$ & 0.76 & 0.46 & 1.02 & 158 & 123 \\
\hline Hair Dryer ${ }^{1}$ & $3 \%$ & 1.13 & 0.36 & 1.03 & 4 & 3 \\
\hline $\mathrm{A} / \mathrm{C}^{5}$ & $2 \%$ & Not Available & 5.24 & Not Available & 40 & 31 \\
\hline Refrigerator $^{6}$ & $72 \%$ & Not Available & 1.28 & Not Available & 336 & 261 \\
\hline Other & & & & & 18 & 14 \\
\hline Total & & & & & 1839 & 1427 \\
\hline
\end{tabular}


Source of information for calculating daily energy use:

1 Wattage data from Association of Home Appliance Manufacturers of Philippines used in conjunction with hours/day data from survey

2 Annual consumption from Metering Matters $^{10}$ divided by 365 to obtain daily consumption

3 Wattage data along with hours of operation obtained from the survey

4 Wattage data from APEC Proceedings ${ }^{11}$ used in conjunction with hours/day data from survey.

5 Annual consumption from Thailand: Promoting Electricity Energy Efficiency, Pre-Investment Appraisal divided by 365 to obtain daily consumption

6 Average annual consumption for new refrigerators in Thailand with efficiency rating of 3.

\subsection{POTENTIAL FOR ELECTRICITY SAVINGS}

Figure 1 suggests that lighting, fans, refrigerators and televisions are responsible for $75 \%$ of the total household electricity consumption (1460 kWh/y per household) in urban Sri Lanka. Tthe biggest potential for savings also lies with these end-uses. We make some rough estimates below of potential energy savings for these four products and also for pumps.

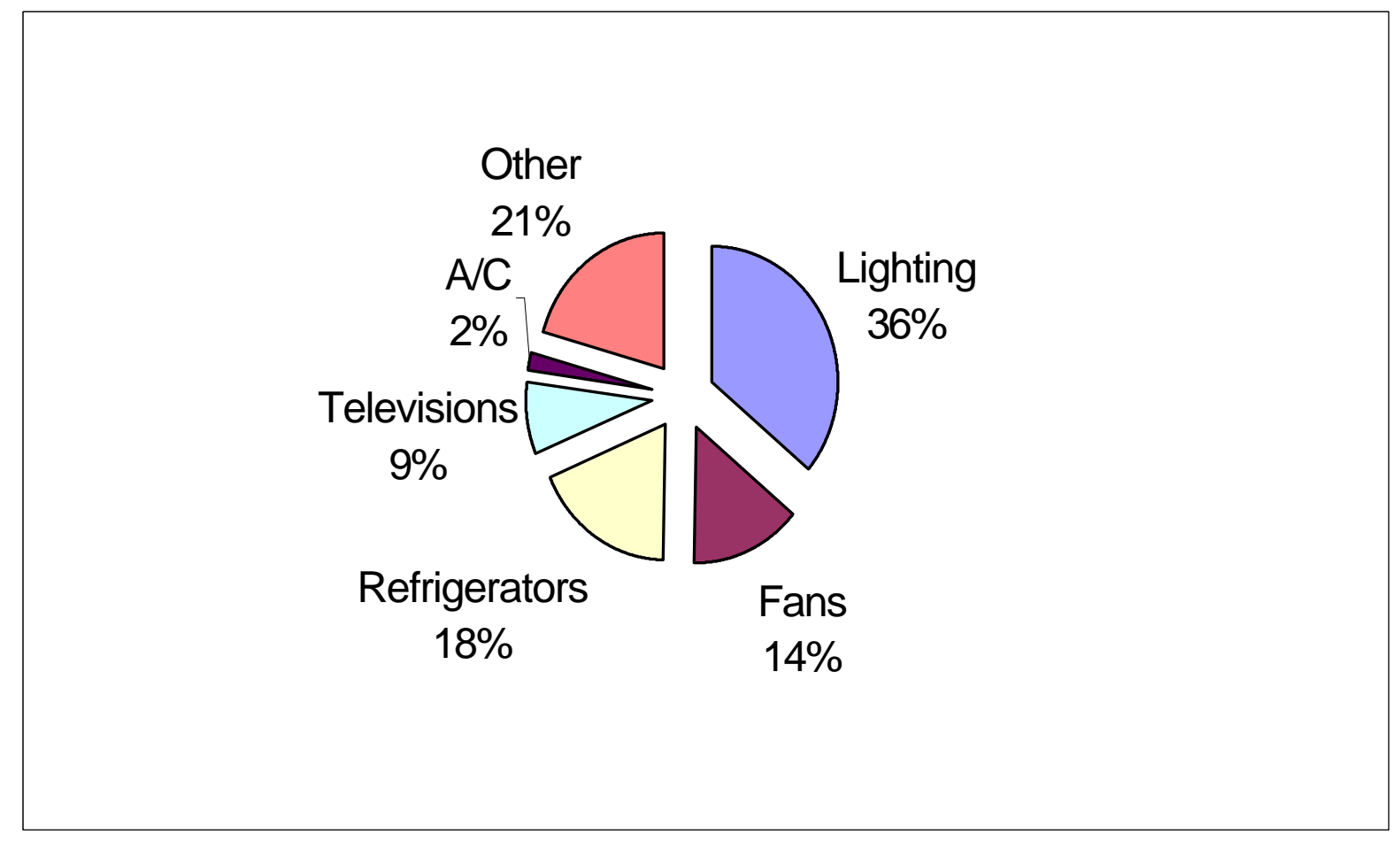

Figure 2.1 Major contributors to household energy consumption in urban Sri Lanka

\section{Lighting}

Assuming an energy efficiency policy that requires $50 \%$ of the incandescents to be replaced by compact fluorescents, we can calculate the electricity consumption for a household by assuming 
18.4 Watt compact fluorescents in place of 58.4 Watts for half the incandescents used. This results in an incandescent lighting electricity consumption per household of $375 \mathrm{kWh} / \mathrm{y}$ and a total household lighting electricity consumption of $469 \mathrm{kWh} / \mathrm{y}$. Furthermore, a more efficient ballast driving the fluorescent lamps could further reduce lighting energy use. Assuming a ballast using 6Watts instead of 10 Watts is used with all fluorescent lighting results in an extra electricity savings of $12 \mathrm{kWh} /$ year per household or $10 \mathrm{GWh} /$ year for the whole of Sri Lanka. Table 2.9 shows the impact of more efficient lighting (including ballasts) on household and national residential energy consumption. This does not include savings due to higher efficiency lighting and ballasts in non-residential sectors of Sri Lanka which is bound to be very significant as well but due to lack of data, LBNL is not in a position to estimate those savings.

\section{Refrigerators}

For refrigerator energy use in Sri Lanka, a more efficient scenario could be a policy to require new refrigerators to meet \#5 level efficiency of Thailand manufactured refrigerators. Based on the data for new refrigerators obtained from Thailand, this translates into an average energy consumption of $372 \mathrm{kWh} / \mathrm{y}$ per refrigerator. Table 2.9 shows the impact of more efficient refrigerators on household and national residential energy consumption.

\section{Fans}

According to a U.S. study on fan efficencies ${ }^{12}$, a $15 \%$ improvement in efficiency is possible for a ceiling fan by using a higher efficiency motor. Extending this assumption to pedestal and table fans as well results in the energy savings listed in Table 1.9. In addition, it is estimated that only $40 \%$ of the fans in Sri Lanka are in the residential sector with the remaining $60 \%$ used in commercial or industrial settings ${ }^{13}$. Use of higher efficiency fans in non-residential sectors would result in a further increase in energy savings not represented here.

\section{Televisions}

Energy saving potential for television use lies in reducing the stand-by power loss in color televisions using remote control units. In the base case, this loss is assumed to be 5.1 Watts. Color televisions with stand-by power loss of 1 Watt for remote control functionality are presently available in the U.S. Table 1.9 shows the impact of televisions with lower stand-by losses on household and national residential energy consumption.

\section{Electric Pumps}

According to the SRC survey, electric water pumps in urban Sri Lanka have a saturation of $18.3 \%$. The survey does not provide any information on size, type or usage of these pumps. However, water pumping is an energy-intensive application and would result in significant energy consumption. In addition to residential use, water pumps are also used in commercial, industrial and agricultural applications. According to a study performed for India ${ }^{14}$, energy used for pumping in India in 1990 was 32 TWh which represented 13\% of India's total energy consumption (238.2 $\mathrm{TWh}^{15}$ ). Assuming the same ratio for pumping energy use to total energy consumption holds true for Sri Lanka in the year 2000, estimated pumping energy use in Sri Lanka is $13 \%$ of $4.04 \mathrm{TWh}^{16}$ or $543 \mathrm{GWh}$. A $10 \%$ improvement in pump motor efficiency would 
save Sri Lanka approximately $54 \mathrm{GWh}$ of electricity per year.

\section{Electric Motors}

The fact that a wide variety of equipment uses motors means any improvement in motor efficiency would result in efficiency improvement in a number of appliances across all sectors of the Sri Lankan economy. Motor systems used in developing countries are often less efficient than their counterparts in industrialized countries. For example, the cost-effective technical potential for reducing electricity consumption in India by improving motor efficiency is estimated at $7 \%$ of projected national electricity use in $2005^{17}$. It should be kept in mind that energy savings due to improved electric motor systems cannot be directly added onto the savings potential in other appliances and electricity using equipment because many of these equipment use electric motor systems. Adding these savings together would result in double counting of savings from electric motor systems.

\section{Air conditioners}

LBNL's experience with other developing countries in this region has shown that as economic conditions improve, air conditioner use sees very rapid growth. In the absence of any data on how air conditioner saturation has changed over the years, it is not possible to project electricity consumed by air conditioners in Sri Lanka. However, since air conditioners use large amounts of electricity and weather conditions in this part of the world encourage high usage rates, they could become a significant portion of household electricity consumption in Sri Lanka and their use and saturation levels should be closely monitored. 
Table 2.9 Impact of Higher Efficiency Appliances on Urban Sri Lanka Residential Electricity Consumption

\begin{tabular}{|l|c|c|c|c|}
\hline End-Use & $\begin{array}{c}\text { Base Case } \\
\text { Household } \\
\text { Consumption* } \\
(\mathrm{kWh} / \mathrm{y})\end{array}$ & $\begin{array}{c}\text { Efficient Case } \\
\text { Household } \\
\text { Consumption } \\
(\mathrm{kWh} / \mathrm{y})\end{array}$ & $\begin{array}{c}\text { Sri Lanka } \\
\text { Household } \\
\text { (kWh/y })\end{array}$ & $\begin{array}{c}\text { Residential } \\
\text { Energy Savings } \\
(\mathrm{GWh} / \mathrm{y})\end{array}$ \\
\hline Lighting & 664 & 469 & 194 & 151 \\
Ballast & 31 & 19 & 12 & 10 \\
Fans & 262 & 223 & 39 & 31 \\
Refrigerators & 336 & 267 & 69 & 54 \\
Televisions & 157 & 127 & 30 & 23 \\
\hline Total & & & 345 & 268 \\
\hline$\%$ Savings & & & $18.8 \%$ & $18.3 \%$ \\
\hline
\end{tabular}

* calculated as UEC x Saturation

\subsection{CONCLUSION}

Improving the efficiency of 5 of the leading appliances in Sri Lanka can result in electricity saving of approximately $345 \mathrm{kWh} / \mathrm{y}$ per household or $268 \mathrm{GWh} / \mathrm{y}$ for the whole of Sri Lanka. This is equivalent to a reduction of approximately $19 \%$ of an average household electricity bill or reducing the residential electricity consumption of Sri Lanka by 18\% of its 1999 consumption of $1468 \mathrm{GWh} / \mathrm{y}$. Assuming an average electricity rate of Rs 4.45 per $\mathrm{kWh}$, this will amount to a saving of Rs 1193 millions per year in 2000 Rupees for consumers of Sri Lanka in electricity bills. However, it is likely that some of these savings will be diminished due to the higher initial price a consumer has to pay to acquire a higher efficiency appliance. In addition, if savings due to improved electric pumps is included, the total annual electricity consumption in Sri Lanka can be reduced by $322 \mathrm{GWh}$ or $8 \%$ of the 1997 level of $4039 \mathrm{GWh}$. This number does not include potential savings from higher efficiency fans and lighting in the non-residential sectors. The electricity savings estimated are based on the assumption of conversion of the entire stock of lighting and appliances to higher efficiency levels. This, obviously, will take time as the present stock is retired and new, more efficient appliances take their place. It is estimated that at the point of peak electricity savings, 102 MW of capacity savings will be realized calculated as follows for each end-use.

Capacity Savings $=$ Electricity Saved x $(1+$ T\&D Losses $) \mathrm{x}(1+$ safety margin)/(hrs used per year) 
where we have assumed Transmission and Deliver losses at 18\% and a safety margin on $25 \%$.

In future years, savings at the national level are likely to increase as the saturation of appliances in Sri Lanka increases. Even though the electricity saved will increase as the number of appliances in Sri Lanka increases, the impact on individual consumer's bills will depend upon electricity rates at that time with savings increasing if price of electricity rises and vice versa. 


\section{REFERENCES}

1. CEB-DSM and Load Research Project—Residential Sector Electricity Use Survey.

2. Economic and Social Statistics of Sri Lanka - 1998. Central Bank of Sri Lanka.

3. Data obtained through email exchange from Sood R. Na Phuket of IIEC.

4. Proceedings: Workshop on Setting-Up and Running an Energy Performance Testing Laboratory - 1999. Sponsored by Asia Pacific Economic Cooperation. Published by IIEC.

5. Energy Use of Television and Videocassette Recorders in the U.S., March 199, LBNL for U.S. DOE.

6. Ibid.

7. Ibid.

8. Meyers S, Monahan P, Lewis P, Greenberg S, Nadel S, Electric Motor Systems in Developing Countries: Opportunities for Efficiency Improvement, August 1993, LBL34412.

9. IIEC, Thailand: Promoting Electricity Energy Efficiency, Pre-Investment Appraisal, Prepared for The World Bank/Global Environmental Facility, United Nations Development Program. February 1993.

10. Metering Matters, Appliance Efficiency: Newsletter of IDEA, the International Network of Domestic Energy Efficient Appliances. Issue 4, volume 3, 1999.

11. Proceedings: Workshop on Setting-Up and Running an Energy Performance Testing Laboratory - 1999. Sponsored by Asia Pacific Economic Cooperation. Published by IIEC.

12. Danny Parker, Michael Callahan, Jeffery Sonne, Guan Su, Development of a High Efficiency Ceiling Fan, Florida Solar Energy Center, 1999.

13. Conversation of Peter Biermayer of LBNL with Harinee de Costa of Hayleys Electronics Limited of Sri Lanka.

14. Gautam Dutt, Energy End Use - An Environmentally Sound Development Pathway. Published by Asian Development Bank.

15. IEA Statistics, Energy Statistics and Balances of Non-OECD Countries 1992-1993.

16. Economic and Social Statistics of Sri Lanka - 1988. Central Bank of Sri Lanka. 
17. Meyers S, Monahan P, Lewis P, Greenberg S, Nadel S, Electric Motor Systems in Developing Countries: Opportunities for Efficiency Improvement, August 1993, LBL34412. 


\section{Task 3 - SUMMARIZE THE ANTICIPATED BENEFITS AND COSTS FROM THE ESTABLISHMENT OF A TESTING FACILITY}

\subsection{INTRODUCTION}

In this section, we summarize (the details are shown in task 6) the costs and benefits of setting up and running a testing facility and labeling program in Sri Lanka. The costs include personnel to administer and enforce the labeling program, staff the testing facility, write the regulations, collect the data, handle disputes, etc. and hard costs such as the land, building and equipment required to establish the facility. Such a facility will also need to plan for operating, maintaining and upgrading equipment over the life of the testing, labeling and standards program.

The benefits of a labeling and testing facility arise from the ability to measure and compare the efficiencies of similar models of a product. The benefits include reduced electricity use and the concomitant benefits, such as reduced power plant emissions, reduced need for new power plants, and higher consumer disposable income. Other benefits, which we will not estimate quantitatively, are improved competitiveness for local manufacturers, increased cash flow in the economy, and reduced need to import fuel for power plants.

The CEB generates most of the electric power in Sri Lanka. They expect the fraction delivered by hydro power plants to decrease from about $63 \%$ in 2000 to $31 \%$ in 2013. The remaining demand will be met by thermal power plants ${ }^{1}$. At the present time, the fuels used for thermal power are diesel and oil; coal is expected to dominate beginning in 2004. By 2010, coal is expected to supply more than $90 \%$ of the fuel requirements.

\subsection{BENEFITS}

The direct benefits that would accrue from a testing facility are the ability to label energy using products with respect to their energy use or efficiency. Labels inform consumers about the relative efficiencies of alternative models of a product they may wish to purchase. Labeling alone can cause an improvement in average energy efficiency. However, the improvement from labeling is uncertain and difficult to estimate and is smaller than what can be obtained from performance standards. The efficiency data resulting from testing also facilitates the responsible government agency in establishing efficiency standards.

In Task 2, unit electricity savings, national electricity savings, unit electricity cost savings and national electricity cost savings were estimated for several products that could be candidates for efficiency standards. A number of assumptions had to be made in order to perform the analyses in Task 2 and Task 3; we explain the assumptions as we proceed. The energy savings and electricity cost savings were calculated assuming the stock of appliances had been replaced with new more efficient models. Therefore, those estimates represent the maximum national annual energy and energy cost savings. In reality, the benefits grow as the stock is replaced by the more efficient models. In calculating the benefits at the power plant, we assume that hydro is the baseline power source and that the reduced residential sector energy use lowers the generation of electricity by the thermal plants. 


\section{Life Cycle Cost}

Life cycle cost (LCC) is the total cost of purchasing and operating an appliance over its lifetime. In Task 2 we have already calculated the unit energy savings and the unit energy cost savings for consumers of each of four products. The benefits to individual consumers in reduced electricity bills is partially offset by the increased price of the more efficient appliances or lighting equipment. Since we do not have any purchase price data for the products analyzed in Sri Lanka, we have to estimate the incremental price to calculate LCC. For this purpose, we decided to use data from previous U.S. studies. Some recent standards analyses for refrigerators and ballasts indicate that, for the chosen efficiency standard, the incremental equipment price averaged about 4 times the annual electricity cost savings for the first year (equivalent to a 4 year payback period). We do not have such studies for televisions or fans. For the purpose of this study, we will use a ratio of 4 for the incremental price to annual benefit ratio for all four products. This assumption is made for illustrative purposes only, and is not meant to be represented as an accurate estimate of actual incremental prices. We wanted to be sure that incremental prices are accounted for in future calculations when additional data may be available. We have also assumed a life of 15 years for all the appliances considered and a constant Rs $4.45 \mathrm{kWh}$ rate for electricity. The annual electricity cost savings are discounted at $7 \%$ to account for the time value of money. The resulting life cycle costs savings are presented in the table below. Prices and savings are in year 2000 rupees.

Table 3.1 Life Cycle Cost Savings for Selected Appliances in Sri Lanka

\begin{tabular}{|l|c|l|l|l|}
\hline & $\begin{array}{l}\text { Electricity } \\
\text { Annual Electricity } \\
\text { Rate } \\
\text { Saved (kWh/y) }\end{array}$ & $\begin{array}{l}\text { Annual Savings } \\
(\mathrm{Rs} / \mathrm{kWh})\end{array}$ & $\begin{array}{l}\text { (Rs/y) } \\
\text { Incremental } \\
\text { Price (Rs) }\end{array}$ \\
\hline Lighting & 194 & 4.45 & 865 & 3461 \\
Ballast & 12 & 4.45 & 55 & 221 \\
Fans & 39 & 4.45 & 175 & 700 \\
Refrigerators & 69 & 4.45 & 307 & 1227 \\
Televisions & 30 & 4.45 & 135 & 539 \\
\hline Total & & & & \\
\hline
\end{tabular}

\section{Net Present Value}

Net present value is the difference between discounted electricity cost savings for all appliances sold over some time period less the incremental price for those same appliances. Since we do not have either the sum of the incremental prices or the discounted energy cost savings, assumptions had to be made to calculate NPV. Typically, a time stream of annual energy savings is needed to carry out an NPV estimation. In our case, we have only the maximum annual energy savings. We discuss below the approximation needed to generate a series of annual energy savings. 
Data from a refrigerator analysis is used to estimate the relationship between the sum of the annual energy savings values and the maximum annual energy savings. We found that ratio to be 22 for refrigerators for 30 years (from 2001 to 2030). In order to calculate the NPV, we have assumed that the energy savings estimated in this analysis represent the maximum energy saved as a result of the entire stock of present appliances being replaced by more efficient appliances. This conversion is a slow process and will be completed over a period of several years. The total energy saved over a period of 30 years is then calculated as 22 times the maximum energy saved. We then obtained the annual energy saved by dividing the total energy saved by 30 . This assumes that energy savings are constant from year to year which is not true as annual energy savings increase initially as the present stock is replaced by higher efficiency appliances over the years until all the present appliances have been retired (the point of maximum annual energy savings). The value of the total energy saved is then obtained by using a rate of Rs 4.45 per $\mathrm{kWh}$ and discounting the annual energy cost savings by $7 \%$ resulting in Rs 10,856 million in energy cost savings over a period of 30 years.

Analyses for ballasts and refrigerators indicated that the sum of the incremental prices divided by the sum of the discounted cumulative electricity cost savings over a 30 year period ranged from 25 to $50 \%$. Therefore, when calculating the net present benefit (discounted benefit less the incremental price), we will assume that the present value of the incremental price is $37 \%$ of the discounted electricity cost savings. The increase in purchase price of the more efficient equipment is calculated as 0.37 times the value of the discounted energy cost savings and comes out to be Rs 4,017 million. The NPV is thus calculated to be Rs 6,840 million. The value of NPV so calculated is likely to be higher than the true NPV because we have distributed the cumulative electricity savings equally across all the 30 years under consideration.

$\mathrm{NPV}=$ Present value of energy cost savings -present value of incremental equipment price

NPV $=$ Present value of annual energy cost savings $-0.37 *$ Present value of energy cost savings

Present value of energy cost savings $=(22 *$ maximum annual energy cost savings $/ 30) * \mathrm{PWF}$ $(0.07,30)$

where $\operatorname{PWF}(0.07,30)$ is present worth factor when discount rate is $7 \%$ and the time series is 30 years in duration and comes out to be 12.4 .

In reality there are more savings in the latter years than in the earlier years and the effect of these latter savings on the NPV is lower due to discounting. This analysis also does not take into account the increase in population of Sri Lanka as well as the increase in the saturation level of appliances, each of which would result in higher savings and NPV. As is the case for the LCC calculation, these assumptions for the calculation of NPV are made for illustrative purposes only 
and it is expected that estimates will be improved when additional data are available.

\section{Power Plant Emissions Reductions}

In order to calculate reductions in emissions of nitrogen oxides (NOx), sulfur dioxide (SOx) and carbon, we assumed that any electricity use reductions in the residential sector resulted in an equivalent reduction in power generated by coal. The emission reductions calculated here are for the year of maximum energy savings. Assuming that efficiency standards take effect in 2003, maximum energy and emission savings may not occur until around 2018. Table 3.2 below shows the emission factors chosen for this analysis and the estimated emission reductions. These emission factors include an $18 \%$ transmission and delivery loss.

Table 3.2 Emission Factors and Emission Reductions from Efficiency Standards: Coal-fired Power Plants

\begin{tabular}{|l|l|l|}
\hline Pollutant & $\begin{array}{l}\text { Emission Factor } \\
(\mathrm{kg} / \mathrm{kWh})\end{array}$ & $\begin{array}{l}\text { Emission Reduction } \\
\left(\text { metric tons/yr }{ }^{*}\right.\end{array}$ \\
\hline Carbon & 0.399 & 106.9 \\
\hline Nitrogen Oxides & 0.002 & 0.7 \\
\hline Sulfur Dioxide & 0.009 & 2.3 \\
\hline
\end{tabular}

* Annual reduction in emissions at year of maximum energy savings.

\section{Avoided Capacity Savings}

In addition to a reduction in energy use in the residential sector, there is also a reduction in demand. This reduction in demand should result in fewer power plants being added to the national grid. In 1997, the total installed capacity connected to the national grid was about $1700 \mathrm{MW}$. The maximum demand from the national grid was 1037 MW in 1997. Total electricity sales in 1997 was $4039 \mathrm{GWh}$. Assuming that coal-fired plants are added to the grid to meet future demands, the total avoided capital cost is between 1100 and $1300 \mathrm{US} \$ / \mathrm{kW}^{2}$. If the potential demand reduction of $102 \mathrm{MW}$ estimated in task 2 is realized, it would yield a capital cost savings of 112 to 132 million dollars or 7.8 to 9.2 billion Rupees (assuming an exchange rate of US $\$ 1=$ Rs 70 Sri Lankan). If we assume that one power plant is avoided 10 years out after standards go into effect, then we need to discount the avoided costs. The discounted savings will be about half of the values noted directly above.

\subsection{COSTS}

Summarizing from task 6 , the cost of constructing a testing facility (for lighting, air conditioners, refrigerators, ceiling fans, televisions and motors) would be about $\$ 2$ million in the first year and 
approximately $\$ 118,000$ per year for the next 29 years. If we discount the $\$ 118,000$ per year expenditure for the 29 years at a $7 \%$ discount rate, the total present value of expenditures for the 30 years is 1.3 million dollars (U.S.). This should be compared to the national cost savings estimated from the establishment of efficiency standards. Table 3.3 summarizes the benefits and costs. We have not included the benefits from room air conditioners, and motors in this analysis yet the benefits from the four products considered outweigh the cost of constructing and operating a test facility, labeling products, and establishing test procedures for six products. We have also not included the environmental benefits in the table at this time although there is a monetary health benefit associated with reduced emissions of sulfur dioxide and nitrogen oxides. There may be monetary benefits associated with reduced carbon emissions too. If these monetary benefits become available in the future, they could be added to the total benefits.

Table 3.3 Summary of Estimated Benefits And Costs to Nation From Test Facility

\begin{tabular}{|l|l|l|}
\hline & \multicolumn{1}{|c|}{$\begin{array}{c}\text { Present Value of Cost } \\
\text { (US \$) }\end{array}$} & \multicolumn{1}{|c|}{$\begin{array}{c}\text { Present Value of Benefit } \\
\text { (US \$) }\end{array}$} \\
\hline $\begin{array}{l}\text { Testing Facility, Labeling \& } \\
\text { Standards Costs }\end{array}$ & 3.3 million & 97.7 million \\
\hline $\begin{array}{l}\text { Net Present Benefit to } \\
\text { Consumers }\end{array}$ & & 61 million \\
\hline Avoided Capacity Cost & & \\
\hline
\end{tabular}




\section{REFERENCES}

1. Ceylon Electricity Board, Long Term Generation Expansion Planning Studies, 19982012, Generation Planning Branch, CEB, Colombo, Sri Lanka, June 1998.

2. Ceylon Electricity Board, Long Term Generation Expansion Planning Studies, 1998-2012, Generation Planning Branch, CEB, Colombo, Sri Lanka, June 1998. 


\section{Task 4. ORGANIZATIONAL STRUCTURE}

\subsection{INTRODUCTION}

In this section of the report, we describe the findings of our survey of Sri Lankan organizations that could potentially be involved in an appliance testing and labeling program. The main questions we asked are listed below:

- What is the mission and legal mandate of each organization?

- What are the human resources and skill sets of each organization?

- What is the best potential role for each organization in an appliance testing and labeling program?

We conclude this section by proposing an organizational structure for the Sri Lanka Appliance Testing and Labeling Program. We present an action plan for the program in the following section entitled "Task 5. Action Plan: Energy Testing and Labeling Regime."

\subsection{ORGANIZATIONAL SURVEY}

The following survey is based on research conducted and interviews performed with key stakeholder organizations during missions to Sri Lanka, in December 1999 and February and March 2000.

\section{Ceylon Electricity Board}

Under the Ceylon Electricity Board Act, No. 17 of 1969, CEB's mandate includes the following activities:

- "Carrying out investigations and to collect and record data concerning the generation, distribution, and utilization of power..."

- "Promoting the standardization of the system of supply of all types of electrical fittings and equipment."

- "Conducting research into matters affecting the generation, distribution, transmission, supply and use of electricity."

In addition, the DSM Branch within CEB has a specific mission to assist customers to use electricity more efficiency. The Demand-Side Management Unit was established in 1995 under the direction of the Chief Engineer in the Planning Division. In 1997, it was upgraded to a Branch under a Deputy General Manager in the Commercial Division. The DSMB has the mandate to "plan, implement, and monitor all DSM activities within CEB. The mission of CEB is to "assist CEB to provide affordable, clean, reliable, and sustainable service by encouraging 
and facilitating efficient use of energy by customers."1

The DSMB is the chief implementing agency of the Sri Lanka Energy Services Delivery Project, which is co-funded by the World Bank and the Global Environment Facility. A key element of this project is a DSM and Load Research Project, which is currently being implemented by the DSMB with assistance from the prime consultant, SRC International Pty. Ltd.

\section{Sri Lanka Standards Institution (SLSI)}

The mission of SLSI is to set standards for the safety and performance of products used in Sri Lanka in order to protect consumers and users of such products and equipment. Under the Sri Lanka Standards Institution Act, No. 6 of 1984, SLSI has the mandate to:

- "Prepare standards on a national and international basis."

- "Make arrangements or provide facilities for the testing and calibration ... so as to comply with the required standards."

- "Operate a certification marks scheme in accordance with the relevant provisions of this act."

SLSI manages standards for all products produced and imported into Sri Lanka. SLSI oversees the Electrical and Electronics Laboratory (EEL), which has 7 staff. The EEL was established in 1983 "in order to provide a service to electrical product manufacturers and importers to improve the quality of their products, and to safeguard consumer interests in safety and reliability of electrical products." 2 The lab measures safety and performance of switches, plugs, sockets, electrical equipment, and some lighting equipment. It also performs lifetime testing of incandescent lamps. SLSI has a compulsory marking scheme ("SLS" mark) for 56 products, of which 9 are electrical products. Notes from the visit to the SLSI test laboratory can be found in Appendix A.

\section{Energy Conservation Fund (ECF)}

Under the Energy Conservation Fund Act, No. 2 of 1985, ECF is mandated to:

- "Identify available technologies for improving efficiency."

- "Identify policy measures that can be enforced."

- "Promote a programme on energy efficiency demand management and conservation and provide funds for the development and promotion of energy conservation programmes initiated by any institution."

- "Assist public and private sector institutions to embark on energy efficiency demand management or conservation programmes."

ECF has eight professional and 22 support staff. Professional staff are the Chairman, General

\footnotetext{
${ }^{1}$ SRC International, 1999.

2 SLSI brochure: "Testing of Electrical Products."
} 
Manager, Director of Projects, Director and Assistant Director of DSM and Energy Management, Deputy Director and Assistant Directors of Awareness Programs, two engineers (mechanical and electrical), one Assistant Director for DSM and Energy Management. ECF is also beginning to set up provincial offices in seven provinces. Each province will have one technical officer in charge, a technical assistant, and three support staff. Notes from the meeting with the ECF Chairman can be found in the Appendix A.

\section{Department of Internal Trade}

Under the Consumer Protection Act, No. 1 of 1979, DTI has the following mandates related to product performance and labeling:

- "The Commissioner may, for the protection of the consumer, issue general directions to manufacturers or traders in respect of labeling,..."

- "The Commissioner may inquire into complaints regarding the manufacture or sale of any article which does not conform to the standards and specifications ... [including those] prescribed by the Bureau of Ceylon Standards."

- The Commissioner also has authority to inspect, search, and issue fines.

DIT has 24 districts, with different officers in each district. The DIT staffing quota is a total of 280 officers, but only 190 are active at present. In order to issue a labeling direction, DIT could hire more staff, and all DIT staff would need to be trained.

DIT has the authority to issue Product Standards or "Directions". For example, once a standard is declared by SLSI, DIT can issue a "Direction" and it becomes mandatory. DIT is authorized under the 1979 Consumer Protection Act (Section 6(1')(c)) to issue mandatory Directions. Directions currently exist for switches, plugs, lamp holders, electric hot plates, GSLs (tungsten filament lamps), fluorescent lamps. Directions can also be issued if there is a demand from a government agency. For example, to request mandatory energy labels, CEB could request a direction and provide supporting evidence of the need or benefit. The request would be made at the Ministerial level -- from the Ministry of Irrigation and Power to the Ministry of Internal and International Commerce and Food (where DIT resides). The Direction would be published in the government Gazette and then become law. This would make it mandatory for all manufacturers to comply. Notes from the meetings with DTI administrators can be found in the Appendix A.

\section{The Role of Industry}

During our meetings with the Chambers of Industry and Commerce, their representatives expressed support for the proposed Appliance Testing and Labeling Program (see below and in Appendix A). In fact, the profit incentive and competitive and forces in the market can be used as a strategy for monitoring and enforcement of compliance and to highlight false claims. In the U.S., for example, there is a challenge system that allows manufacturers of an appliance to issue a challenge against a competitor that it suspects of reporting false information about their product's energy performance. The challenge system works reasonably well in the competitive 
U.S. market place, and should be considered as an option for improving program compliance in Sri Lanka.

\section{Environmental Scan of Support and Opposition}

In the implementation of any new government program, it is useful to identify potential supporters and opponents of the policy, and to understand their motivations and concerns. CEB has done an excellent job of laying the groundwork for the future success of an energy testing and labeling program by forming an Appliance Energy Labeling Steering Committee, which has been meeting regularly over the past several months during the course of the feasibility study. The Steering Committee comprises all major stakeholders in the implementation of such a program, and the discussions to date have helped the consultants and CEB's DSMB to identify some of the potential barriers to successful implementation of a program. The roster of the Steering Committee is listed in the Appendix B.

Based on the discussions at the Steering Committee meetings, as well as our individual meetings with the various stakeholders during the course of missions to Colombo in December 1999 and February 2000, we can make the following general observations.

CEB, ECF, and SLSI will all likely have a major role in implementing the program and should be among the strongest supporters of the program. Additionally, DIT may have a role in labeling and enforcement, and ITI may have a role in product testing, and these organizations should be expected to be supportive. Within the NGO sector, it was mentioned that an NGO called the Housewive's Association could potentially be a strong supporter of the labeling program.

Our interviews with the Chambers of Commerce indicated that they would be likely to support the program, but their representatives expressed concerns that the program could lead to bureaucracy and inefficiencies that might limit its effectiveness (and presumably their support for the program). Their concerns included the process of certifying imports and the process for testing equipment. For example, they expressed concerns about the ability of SLSI and the Customs Department to handle the logistics of implementing a new program like this. The importers of ballasts and lamps, especially lower-quality products from China and India, might be expected to object. The Chinese and Indian embassies might object to this program, and a member of the Steering Committee recommended that their commercial counselors be notified early on and invited to a Steering Committee meeting to learn about the program and voice their concerns.

\subsection{ORGANIZATIONAL SKILLS}

We developed the following skills matrix in order to assess the strengths and capabilities of the various stakeholders, with regard to implementing an energy testing and labeling program. This matrix was used as a first step in identifying and proposing roles for implementing the Appliance Testing and Labeling Program. 
Table 4.1. Skills Matrix for Sri Lanka Stakeholders

\begin{tabular}{|l|c||c|c|c|c||c|c|}
\hline Task & SLSI & CEB & ECF & DIT & ITI & Industry $^{\mathrm{a}}$ & Customs $^{-1}$ \\
\hline $\begin{array}{l}\text { Administer labeling } \\
\text { program }\end{array}$ & $\checkmark$ & $\checkmark$ & $\checkmark$ & & & $\checkmark$ & \\
\hline Select products & $\checkmark$ & $\checkmark$ & & & & & \\
\hline Select test procedures & $\checkmark$ & & & & & & \\
\hline Establish test facility & $\checkmark$ & $\checkmark$ & & & $\checkmark$ & & \\
\hline Accredit test facility & & & & & & & \\
\hline $\begin{array}{l}\text { Conduct public } \\
\text { awareness campaign }\end{array}$ & & $\checkmark$ & $\checkmark$ & & & $\checkmark$ & \\
\hline $\begin{array}{l}\text { Establish minimum } \\
\text { efficiency standards }\end{array}$ & $\checkmark$ & $\checkmark$ & & & & & \\
\hline $\begin{array}{l}\text { Enforce labeling and } \\
\text { standards }\end{array}$ & $\checkmark$ & & & $\checkmark$ & & & $\checkmark$ \\
\hline $\begin{array}{l}\text { Monitor \& evaluate } \\
\text { program }\end{array}$ & & $\checkmark$ & $\checkmark$ & $\checkmark$ & & & \\
\hline
\end{tabular}

${ }^{\mathrm{a}}$ Industry refers to the Chambers of Commerce and Industry and other trade associations

\subsection{PROPOSED ORGANIZATIONAL ROLES}

Based on our assessment of the organizational missions and mandates, in combination with individual interviews with each of the major stakeholders, we propose leading and supporting roles for each of the major tasks associated with the Appliance Testing and Labeling Program (see Table 4.2). In addition, since it is envisioned that this program will lead to the development of minimum energy performance standards, we also propose roles for the development of such standards. Figure 4.1 is a schematic diagram of the concept for the operation of the Appliance Testing and Labeling Program. 
Table 4.2 Proposed Organizational Responsibilities

\begin{tabular}{|l||c||c||}
\hline \hline Task & Lead Agency & Assisting Agency \\
\hline \hline Administer labeling program & CEB/ECF $^{\mathrm{a}}$ & \\
\hline \hline Select products & CEB $^{\mathrm{a}}$ & \\
\hline Select test procedures & SLSI $^{\mathrm{a}}$ & MIP $^{\mathrm{d}}$ \\
\hline \hline Establish and operate test facility & $\mathrm{CEB}^{\mathrm{a}}$ & SLSI, ITI \\
\hline \hline Accredit test facility & $\mathrm{NA}^{\mathrm{b}}$ & \\
\hline \hline Conduct public awareness campaign & $\mathrm{ECF}^{\mathrm{C}}$ & CEB \\
\hline \hline Establish minimum efficiency standards & $\mathrm{ECF}^{\mathrm{c}}$ & SLSI \\
\hline \hline Enforce labeling and standards & $\mathrm{CEB}$ & ECF, DTI, SLSI \\
\hline \hline Monitor \& evaluate program & $\mathrm{ECF}$ & CEB \\
\hline
\end{tabular}

${ }^{a}$ In consultation with Steering Committee

${ }^{\mathrm{b}}$ According to our understanding, there are no laboratory accreditation institutions in Sri Lanka.

${ }^{\mathrm{b}}$ Should be done through the Ministry of Irrigation and Power

${ }^{\mathrm{d}}$ Ministry of Irrigation and Power

Figure 4.1 Schematic of the Appliance Testing and Labeling Program

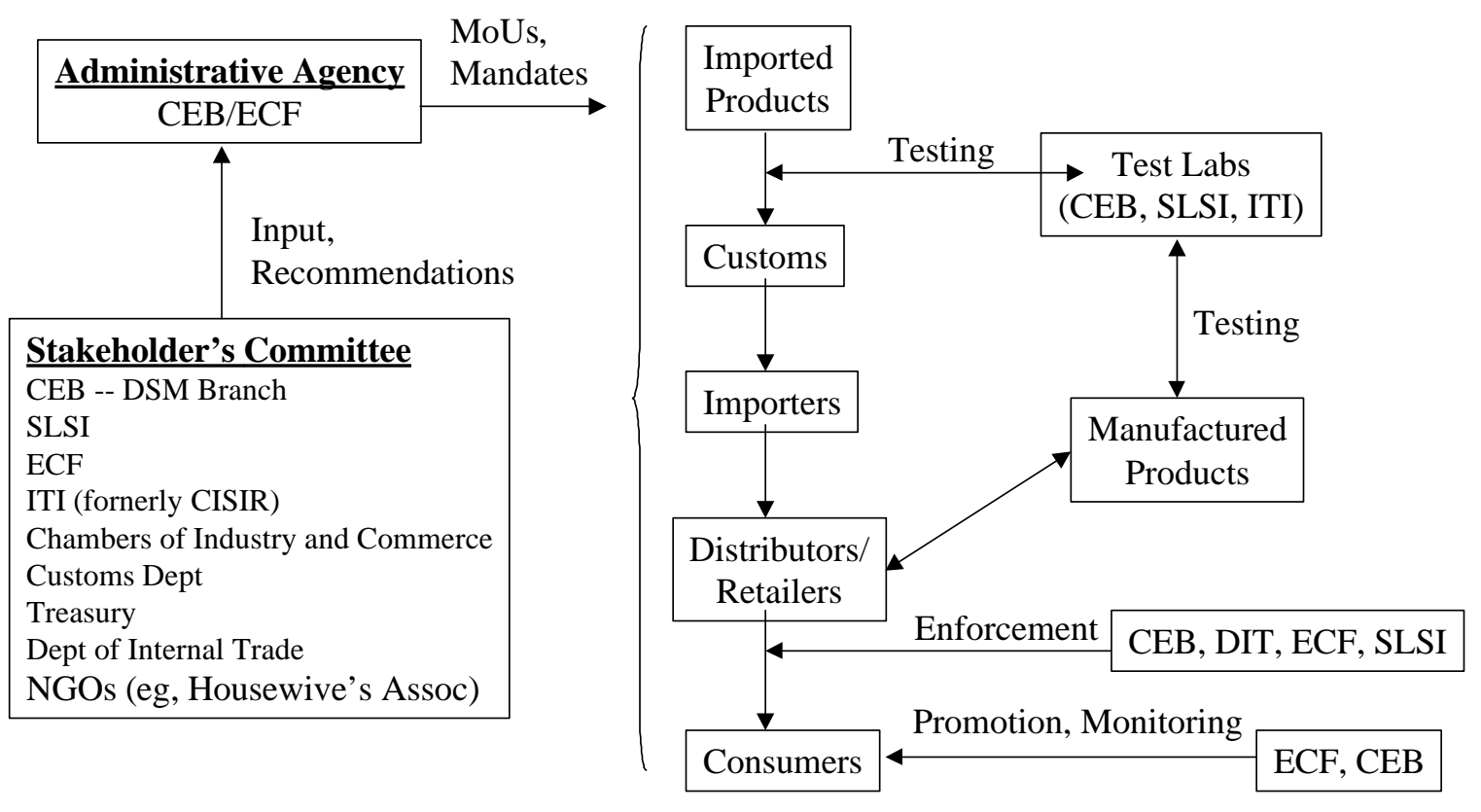

\section{Administer Labeling Program}

Since the likely source of funding for the appliance testing laboratory and labeling program will come to CEB, then CEB should bear the major primary responsibility for overall implementation. At the same time, ECF has a legal mandate to "promote a programme on energy efficiency demand management and conservation" and to "assist public and private sector institutions to embark on energy efficiency demand management or conservation programmes." 
We thus recommend that either the DSM Branch of CEB or ECF take overall administrative responsibility for the testing and labeling program.

\section{Select Products}

The selection of products for the testing and labeling program should be managed by CEB in consultation with the Steering Committee.

\section{Select Test Procedures}

SLSI has responsibility for selecting test procedures for measuring the safety and performance of consumer products. However, the Ministry of Irrigation and Power has the technical expertise to assess the implication of choosing different testing protocols for measuring product energy performance. We recommend that the selection of test procedures to be used for certifying energy performance should be the joint responsibility of SLSI and the Ministry of Irrigation and Power, in coordination with the Steering Committee.

\section{Establish Test Facility}

The establishment of the test facility should be the responsibility of the agency with the budget to construct it. In this case, CEB plans to use some of its own funds, in addition to loan funds from the Asian Development Bank, to establish a test facility. CEB may choose to implement and staff the test facility itself or to contract with SLSI or ITI to assist with construction and operation of the test facility.

\section{Conduct Public Awareness Campaign}

CEB has the capability to implement a large-scale public awareness campaign and has a built-in information distribution system through its customers and the customers of its subsidiary, Lanka Electric Company (LECO). At the same time, ECF has experience and a strong mandate to develop energy conservation promotion programs and its independent status can provide it with credibility in program promotion. We recommend that ECF have primary responsibility for program promotion, with assistance from CEB.

\section{Establish Minimum Efficiency Standards}

The establishment of minimum efficiency performance standards for appliances and other electrical equipment such as motors should be based upon a benefit cost analysis and weigh the costs to manufacturers and society against the benefits in terms of reduced consumer energy bills and deferred electrical generating capacity. Such an action may well require the passage of new 
legislation called "framework legislation," which would provide the legal basis for the establishment of minimum efficiency standards. It appears that the Ministry of Irrigation and Power is the best placed to develop such standards, with assistance from SLSI.

\section{Enforce Labeling and Standards}

The responsibility for enforcement will vary depending on whether it is a labeling or standards program and whether the program is voluntary or mandatory. We are recommending that the labeling program begin as a voluntary initiative and then become mandatory after a period of one to two years. For this program, we recommend that CEB be responsible for enforcement of the labeling program through its contacts with the participating manufacturers and importers and through its role in the Steering Committee. In the longer term, enforcement responsibility for a mandatory labeling program and for minimum efficiency standards could be the responsibility of DIT, ECF, or SLSI.

\section{Monitor and Evaluate Program}

Monitoring and evaluation is an essential element for program success and is often overlooked. The scheme for monitoring the impact of the labeling program, collecting market data on an ongoing basis, and evaluating program effectiveness should be build into the initial implementation plan. Given its status as an independent government agency charged with promoting energy conservation programs, we recommend that ECF play the lead role in program monitoring and evaluation. CEB could also assist in program monitoring and evaluation. ECF and/or CEB may want to engage outside consultants to actually carry out the evaluation surveys and studies. 


\subsection{REFERENCES}

Department of Internal Trade. 1991. "Directions Issued Under Consumer Protection Act."

Parliament of Ceylon. 1969. Ceylon Electricity Board Act, No. 17 of 1969. Date of assent: 6 June.

Parliament of the Democratic Socialist Republic of Sri Lanka. 1995. Consumer Protection (Amendment), No. 17 of 1995. Certified on 4 September

Parliament of the Democratic Socialist Republic of Sri Lanka. 1985. Energy Conservation Fund Act, No. 2 of 1985. Certified on 9 January.

Parliament of the Democratic Socialist Republic of Sri Lanka. 1984. Sri Lanka Standards Institution Act, No. 6 of 1984. Certified on 27 January.

Parliament of the Democratic Socialist Republic of Sri Lanka. 1980. Consumer Protection (Amendment), No. 37 of 1980. Certified on 25 September

Parliament of the Democratic Socialist Republic of Sri Lanka. 1979. Consumer Protection Act, No. 1 of 1979. Certified on 1 January.

Sri Lanka Standards Institution. 1999. "Draft Sri Lanka Standard for Energy Efficient Rating Fluorescent Lamp Ballasts."

Sri Lanka Standards Institution. Undated. "Electrical and Electrical Products." Brochure describing services provided by Electrical and Electronics Laboratory.

SRC International Pty. Ltd. 1999. "The Role of Demand-Side Management in the Restructured Electricity Market in Sri Lanka. Final Report." October. 


\subsection{APPENDIX A: NOTES FROM MEETINGS WITH STAKEHOLDER ORGANIZATIONS}

\section{Sri Lanka Standards Institute}

Visited the SLSI Test Laboratory and met with M.C. Fernando, Assistant Director, Electrical and Electronics. His laboratory has 7 staff. They measure safety and performance of switches, plugs, sockets, electrical equipment, and some lighting equipment. They perform lifetime tests of incandescent lamps (general service lamps, or GSLs). SLSI has a compulsory marking scheme ("SLS" mark) for 56 products, of which 9 are electrical products: GSLs, batteries, hot plates, flexible cables, household switches (<63 amps), plugs, socket outlets, and lamp holders.

For ballasts and fluorescent tube lamps (FTLs), they do not have reference ballasts and lamps. They have a one-meter integrating sphere to measure luminous flux for incandescent lamps. This is fed by a stabilized DC power supply (+/- 0.5\%). For CFLs, they use a less accurate AC power supply (+/- 1\%).

They do not have a reference lamp for testing CFLs. For importers, they often test lumen output and compare to equivalent lumen output for a GSL lamp. An SLS stamp is required for domestically produced GSL lamps. Samples of all GSLs must be tested by SLSI before they are released from Customs, however, there is apparently no provision for ensuring that imported GSLs have the SLS stamp. There is not testing of imported CFLs, because there is no test facility/capability.

Ballasts. No reference ballasts. But use simple circuit (with $40 \mathrm{~W}$ power source but no lamp) to measure ballast losses. A ballast rating scheme as proposed by SLSI. Problem is that it will automatically give electronic ballasts a 5-star rating (no quality standard for electronic ballasts).

Electronic ballast pilot projects. CEB DSMU has done 2 pilots: (1) 20 Osram CFLs installed at CEB headquarters. All still work after 2 years. (2) in a rural area, 50 ballasts have been installed. Client imported them from Singapore. 20 of the 50 ballasts have failed (a factor may be large voltage variation). CEB would like to implement IEC 928 and 929 for electronic ballasts.

Fans. There is no facility to measure airflow. SLSI rates fans and puts a SLS stamp, but the airflow measurements must be done at the manufacturer's facilities.

Other equipment. Yokogawa meter to measure $\mathrm{V}$, a, W, and power factor and various equipment for measuring resistance, inductive load, etc.

\section{Industrial Technology Institute (formerly known as CISIR) - Clean Technology Project}


CISIR changed its name to ITI 2 years ago. Met with Ranil Dhammapala, coordinator of World Bank project on clean production. The Clean Technology Program is coordinated by ITI, the Ceylon Chamber of Commerce, and the National Development Bank. The Clean Production project is currently focusing on information dissemination. They have a nice web site (www.cleanet.lk), with links to information on several industries and case studies. The DSMU may be able to hook up with this project for some industrial DSM demonstration projects.

Ranil mentioned a financing project called E-Friends (Japanese funding), which provides zerointerest loan funds. He also mentioned the National Energy Research and Development group, under the Ministry of Science and Technology. This group has some energy experience and has apparently done some audits. Ranil mentioned the UK-based Intermediate Technology Development Group (offshoot of Schumacher) which is doing work on small-scale renewables in Sri Lanka. Question remains how ITI can help with the appliance testing and labeling program.

\section{Industrial Technology Institute- Calibration and Measurement Unit}

Met with Nihal Gunasekara, Head of Measurement and Calibration Unit. 9 technical staff. They do the following: (1) product testing in conformity with international standards (2) calibration of industrial instruments and (3) industrial measurements. There is also an Electro Technical Unit at ITI that does repair and maintenance of sophisticated technical equipment. The funding is mainly from government. They charge a nominal (ie subsidized) fee for industry. They do not test refrigerators or $\mathrm{A} / \mathrm{Cs}$, since there has been no demand from importers or manufacturers of these products.

Proposed Ballast Labeling. There is a Sectoral Committee on Electrical Appliances. They worked on the ballast labeling rules. The ballast current for the test was based on 360 ma based on average operating temperatures and conditions of 7 ballast samples, tested by a local University for the DSM Unit. A 5-star rating is given for less than $15 \%$ losses, or $6 \mathrm{~W}$ losses at the $40 \mathrm{~W}$ testing load.

Ballast market. There are some low-loss ballasts available (eg, BG and Atco brands). Standard ballasts cost Rp $80(\sim \$ 1.15)$ and low-loss about Rp 140 ( $\$ 2)$. But low loss models currently have very low penetration.

Lighting. They have a $60 \mathrm{~cm}$ integrating sphere to measure luminous flux. Use for small, 40W and 60W GSL lamps.

Accreditation. They are not officially accredited for most products, but have applied to SLSI for calibration services for (1) mercury glass thermometers and (2) top-loading electronic valences (scales).

Other equipment. Like the SLSI lab, this unit has various meters and equipment for measuring measuring resistance, inductive load, etc., as well as V, a, W and power factor. The SLSI lab appears better funded and was recently (1996) given an array of equipment by Japanese donors. 


\section{Department of Internal Trade (DIT)}

Met with Mr. Dasanayake, Assistant Commissioner. DIT deals mainly with faulty products. They have had some complaints about early failure of CFL. Consumers must submit manufacturer warranty and certificates along with their complaints. They depend on SLSI and CISIR/ITI to test products. These agencies do not always test free of charge, however. SLSI has a compulsory inspection scheme for electrical imported products.

Issuance of Product Standards ("Directions"). DIT monitors implementation of standards. Once a standard is declared by SLSI, DIT can issue a "Direction" and it becomes mandatory. DIT is authorized under the 1979 Consumer Protection Act (Section 6(1')(c) to issue mandatory Directions. Directions currently exist for switches, plugs, lamp holders, electric hot plates, GSLs (tungsten filament lamps), fluorescent lamps.

How Directions are issued. Directions are issued if there is a demand. For example, to request mandatory labels, CEB could request a direction and provide supporting evidence of the need or benefit. (Noel mentioned, for example, that the DSMU had invested Rp10m in the CFL program and it had provided a Rp50m benefit to consumers.) Need to justify why the Direction should be issued. The request would be made at the Ministerial level -- from the Ministry of Irrigation and Power to the Ministry of Internal and International Commerce and Food (where DIT resides). The Direction would be published in the government Gazette and then become law. It would make it mandatory for all manufacturers to comply.

Enforcement of Directions. (1) DIT can inspect, find fault, and prosecute in a court of law. (2) Consumer complaints. DIT can request compensation. DIT can then make an order that the company cannot sell a product for a certain time period. But this has never been invoked. Violators can be prosecuted in a court of law. DIT has recourse through the court, a minimum fine of $\mathrm{Rp} \mathrm{3,000} \mathrm{(} \mathrm{\$ 45)} \mathrm{as} \mathrm{laid} \mathrm{out} \mathrm{in} \mathrm{Section} \mathrm{28(3)} \mathrm{of} \mathrm{the} 1979$ Consumer Protection Act. There is no provision for payments for product testing (ie no budget for SLSI, nor for sample testing). DIT has already mandated 29 stds for labeling, pricing, etc. SLSI used to test for free. Now they charge 6,000-7,000 Rp/test. DIT will not mandate additional standards until they solve the problem of enforcement testing/budget. Under the Fertilizer Act, DIT assists, gets samples, and then ITI or SLSI tests the fertilizer products. Budget for testing comes from the Fertilizer Secretariat. Annual budget is $200,000 \mathrm{Rp}$, which covers basic costs and transportation.

Authority to Issue Labels? A request to require energy labels could come from the Ministry of Power or the Minister of Internal and International Commerce and Food. DIT could then issue a Direction. It would take about 2-3 months to be reviewed. For example, there was a Direction to ban tobacco ads. A presidential task force made this direction. But it turned out that DIT does not have the power to ban ads. So they had to draft new legislation giving DIT the power to ban ads.

Import inspection schemes. These are implemented by SLSI in conjunction with the Import Control Dept, within the Ministry of Internal and International Commerce and Food. 54-56 items have been included under the scheme. These items need to be added to the compulsory 
inspection scheme. Want to avoid monopoly on inspection. Should require joint inspection by SLSI and CEB.

Amendment to 1979 Consumer Protection Act. The Ministry is considering amendments to the 1979 Act. It would amalgamate DIT and the Fair Trading Commission into a Consumer Protection Authority, which would have more authority to effect settlements and prevent mergers. It would provide more powers to the consumer authority and facilitate grievances by setting up a permanent tribunal with quasi-judicial authority. The new, draft Consumer Protection Act is now before the Attorney General. Mr. Dasanayake said it could take a while, even a couple of years, to be passed by Parliament.

\section{Customs Department.}

Met with Mr. Siriwardana of the statistics branch. He is seconded from the Department of Census and Statistics.

How would a labeling scheme work? From a customs point of view, in order to check compliance with a labeling scheme, customs officials would need to have a list of makes and models that had been certified and then use this to check models when they were being imported. All models would have to be tested and then a booklet published for easy reference by customs officials. Would need an independent agency to do this testing and prepare the booklet. He suggested that we need to work with traders, since they have the most to lose (through hassles, extra paperwork) from a mandatory labeling scheme.

\section{Chambers of Commerce and Industry}

Ceylon National Chamber of Industries. Represented by Mr. Asoka Temmekoon, Secretary General and Mr. M. Siriwardana, who deals with energy issues.

Federation of Chambers of Commerce and Industry. Represented by Mr. V.P. Sena Peiris, Small and Medium Enterprise Project.

Chamber of Commerce. Represented by Ranil Dhammapala of CISIR/ITI.

Federation of Chambers of Commerce and Industry is the apex, umbrella group of the chambers and has about 50-60 members.

The National Chamber of Industries represent industrial sector. Have $>300$ members. Used to be a lot more manufacturers, but most industrial products are either only assembled locally or imported as finished products. Mr. Siriwardana represents the CNI on energy matters. He used to work for a refrigerator manufacturer, which has since shut down. He said that CNI is also doing deals on development of renewable energy resources. CNI is trying to lead a renaissance and develop local industry in Sri Lanka. Their strategy is to be anti-dumping, fight against countervailing duties. They would like to strengthen SLSI in order to prevent import and sale of sub-standards electrical equipment. 
In the existing manufacturing sector (excluding mining and construction), there are $\sim 1$ million jobs. Sri Lanka has lost of lot of manufacturing jobs over the past decade, but it is very hard to quantify how many. Government does not provide statistics on this. But over an 18 month period, CNI counted 270 closed down (based on reading mortgage sales in the newspaper.

BoI-promoted companies are moving more and more to the local market. BoI rules allow promoted companies to sell only up to $10 \%$ of local output to domestic market. So the BoI companies are selling more of their products locally, and sometimes more than the $10 \%$ market. This is not well policed. The effect is to crowd local producers out of the market. End result is that the government loses revenues, and the profits go abroad.

Support for Labeling program. Members of the 3 chambers would likely support a labeling program.

They suggested that all importers and producers should get a registration number for the labeling program with the governing agency. This will make it easier for Customs Dept to process legal convoys, which are starting up now.

\section{Energy Conservation Fund (ECF)}

Met with W.R.B. Rajakaruna, head of ECF. He had been sick and did not attend the stakeholders meeting. ECF has 8 professional and 22 support staff. Professional staff are Chairman, GM, Director of Projects, Director and Assistant Director of DSM and Energy Management, Deputy Director and Assistant Director of Awareness Programs, 2 engineers (mechnical and electrical), one Assistant Director for DSM and Energy Management. They are also beginning to set up provincial offices in 7 provinces. Each province will have one technical officer in charge, a technical assistant, and 3 support staff.

His concept of the labeling program is to (1)get SLSI involved b/c Sri Lanka needs to issue internationally recognized standards. (2) need to get clear about who has authority to issue the label; and (3) may need to amend the ECF Act and get this authority. He thinks the ECF Act could be amended in 6 months. He thinks that ECF could both administer the lab and issue labels, but that SLSI could also run the lab.

ECF funding sources. Rp 10 million $(\sim \$ 150 \mathrm{~K})$ per year from the government, plus they also use interest from an endowment they have of Rp 23 million $(\sim 315 \mathrm{~K})$.

ECF personnel issues. They have government/civil service regulations for hiring staff. They could ask for waiver of these regulations and special hiring regulations for the appliance test lab. They could also possibly administer the lab and hire staff on a contract basis. 


\subsection{APPENDIX B: MEMBERS OF APPLIANCE ENERGY LABELING STEERING COMMITTEE}

\begin{tabular}{|l|l|}
\hline \multicolumn{1}{|c|}{ Name } & \multicolumn{1}{|c|}{ Institution } \\
\hline $\begin{array}{l}\text { 1. } \begin{array}{l}\text { Mr.H.Abeysirigunawarden } \\
\text { Ms. J. Dewasurandra }\end{array} \\
\text { 2. } \begin{array}{l}\text { Mr.M.H.R.Tissera } \\
\text { Mr. Siriwardana }\end{array}\end{array}$ & $\begin{array}{l}\text { Customs (Imports \& Tariff) } \\
\text { Customs - Statistics Division }\end{array}$ \\
\hline 3. Mr. A.K. Seneviratne & Ministry of Industrial Development \\
\hline 4. Mr. W.R.B. Rajakaruna & Energy Conservation Fund \\
\hline 5. Mr. P.G.Joseph & Ministry of Science \& Technology \\
\hline 6. Mr. A.Amarasinghe & Legal Department, CEB \\
\hline 7. Dr.B.M.S.Batagoda & Ministry of Environment \\
\hline 8. Mr. M.S. Jayalath & DSM Branch, CEB \\
\hline 9. Mr. K.A. Noel Priyantha & DSM Branch, CEB \\
\hline 10. Mr. Suriarachchi & Dept. of Internal Trade \\
\hline 11. Mr. M.V. Perera & Imports and Exports Control Dept. \\
\hline 12. Ms. Suranjana Vidyaratne & Dept. Of Census \& Statistics \\
\hline 13. Mr. R.P.R Rajapakse & General Treasury \\
\hline $\begin{array}{l}\text { 14. Mr. Samantha } \\
\text { Abewickrama } \\
\text { Mr. Sena Peris }\end{array}$ & $\begin{array}{l}\text { Federation of Chamber of Commerce \& Industries of } \\
\text { Sri Lanka }\end{array}$ \\
\hline $\begin{array}{l}\text { 15. Mr. Dinal Peiris } \\
\text { Mr. Ranil Dammapala }\end{array}$ & The Ceylon Chamber of Commerce \\
\hline $\begin{array}{l}\text { 16. Mr. Asoka Thennakoon } \\
\text { Mr. M. Siriwardana }\end{array}$ & The Ceylon National Chamber of Industries \\
\hline $\begin{array}{l}\text { 17. Mr. Nihal Gunasekara } \\
\text { Mr. A.S. Pannila }\end{array}$ & $\begin{array}{l}\text { Ceylon Institute of Scientific \& Industrial Research } \\
\text { (CISIR) New name ITI }\end{array}$ \\
\hline
\end{tabular}

Updated 9 December 1999 


\section{Task 5. ACTION PLAN: ENERGY TESTING AND LABELING REGIME}

\subsection{INTRODUCTION}

This section is designed to serve as an Action Plan for the development of the Appliance Testing and Labeling Program. It outlines all of primary activities that need to be undertaken to design and implement the various program elements. However, it does not provide detail on each and every task that must be completed. In many cases, it describes a task and then provides a list of questions that need to be answered in order to successfully complete the task. The Action Plan should therefore serve as a guideline for CEB and the Appliance Testing and Labeling Steering Committee as they initiate the program.

The Action Plan envisions eight major steps in design and implementing the program:

- Step 1. Formalize the Appliance Testing and Labeling Program

- Step 2. Develop Testing Capability

- Step 3. Implement a Pilot Voluntary Labeling Program

- Step 4. Enact Legislation to Support Mandatory Labeling and Standards

- Step 5. Implement a Labeling Program

- Step 6. Implement Minimum Energy Performance Standards

- Step 7. Monitor and Evaluate the Program

- Step 8. Revise and Update Labels and Standards

These steps are numbered for convenience, however many of the actions occur in parallel. The Implementation Timeline in Appendix A shows how the tasks relate to each other in terms of timing.

\subsection{STEP 1: FORMALIZE THE APPLIANCE TESTING AND LABELING PROGRAM}

This is the first step in developing the program and involves formal establishment of the Stakeholder Committee and approval of the Action Plan.

\section{Step 1.1 Establish the Stakeholder Committee}

CEB will need to lead the process of formally establishing the Stakeholder's Committee. A number of questions will need to be answered:

- Is the current informal Steering Committee adequate, or should it be more formalized?

- Should the Stakeholder Committee be established as a formal government Sub-Committee? If so, to which agency would the Sub-Committee report?

- Is the Stakeholder Committee's role simply that of an advisor to CEB?

- What will be the decision-making structure and rules of the Stakeholder's Committee?

- Will the Stakeholder Committee require Articles of Incorporation, written ground rules, or a 
charter in order to clarify and codify its operation?

- Are there additional stakeholders (e.g., NGOs) that should be added to the membership of the Committee?

\section{Step 1.2 Approve of the Action Plan}

Once the Stakeholder Committee has been formalized, the next step should be to review and approve this Action Plan. This is an important part of the Stakeholder Committee taking ownership of the Plan. If there are concerns about the Action Plan, they should be addressed and modifications made. For example, for a number of the steps outlined in this Action Plan, committee members may decide to answer the questions posed and make the Plan more concrete and the steps more clearly defined. In addition, the Implementation Timeline (see Appendix 5B) will need to be updated to reflect the committee members' view of a realistic implementation schedule. Once the Action Plan and Implementation Timeline are approved by the Committee, these will serve as the basis for further action and implementation.

\subsection{STEP 2. DEVELOP TESTING CAPABILITY}

Developing testing capability is the most critical first step in any labeling program. In order to initiate the program, there must be access to certified testing laboratories, either governmentowned or private sector laboratories. The results of initial testing of a sample of products can be used to characterize the efficiency of the market, to estimate the potential savings from the labeling program, to serve as the basis developing the label categories, and to provide the energy performance results used to label each product. The labeling program cannot begin until a testing program in place.

\section{Step 2.1 Review and Agree on Priority Products}

In order to develop a testing program, the Stakeholder Committee will need to review this feasibility study and agree on what are the priority products for a labeling program over the next three to four years. This will guide their decisions on which test facilities need to be constructed, and in which order of priority.

\section{Step 2.2 Decide Which Test Facilities Need to be Built}

Once the list of priority products for a labeling program has been finalized, the Committee can match this against the list of existing testing facilities in order to decide what new test facilities will need to be constructed in order to initiate the labeling program. If there is some uncertainty about the status or capabilities of test facilities for certain products, it may be necessary to carry out a laboratory assessment. For instance, the Stakeholder Committee may decide to rely on private sector laboratories for certification of energy performance. In such as case, if private sector laboratories that meet international standards are already in place and accredited, it may 
not be necessary for CEB or the government to commission the construction of a test laboratory for that particular product.

\section{Step 2.3 Develop Funding Sources for Test Facilities}

As soon as the action plan has been finalized, and the priority test facilities determined, CEB can begin to develop funding sources. It is our understanding that CEB plans to use internal funds in addition to a loan from the Asian Development Bank to fund the construction of additional test facilities.

\section{Step 2.4 Decide on Testing Roles}

Once the Committee has decided on which additional test facilities must be constructed, it must decide which organization(s) will perform the energy performance testing. Since CEB will likely be funding additional energy testing facilities, from a combination of its own and outside loan funding, then CEB should decide which organizations will pay a role in implementing the testing program. SLSI and ITI both have staff with experience testing electrical equipment and operate small testing laboratories that test electrical products. The scope of existing testing capability is limited however, and does not currently include key products that will be part of the energy labeling program: refrigerators, air conditioners, compact fluorescent lamps, and electric motors. We recommend that CEB choose between two different models for implementing the testing program.

CEB build the test facilities and hire new CEB staff to operate the laboratories. The advantage of this option is that it provides CEB with direct control over program operation. In addition, CEB has a more favorable salary structure than SLSI, and this may allow it to attract and retain more qualified staff to run the test facilities.

CEB build the test facilities but contract out to SLSI and/or ITI to operate the laboratories. This option would take advantage of the engineering and technical staff at these institutions who already have some years of experience with the testing of electrical equipment.

\section{Step 2.5 Decide on Procedures for Testing Energy Performance}

Energy test procedures are a critical underpinning for all energy programs that seek to measure and improve the energy efficiency of appliances and equipment. SLSI has published formal standards for major electrical products. These standards, which are reviewed in Section 6 of this report, cover product performance and safety, and are generally consistent with international testing protocols for electrical products such as those published by the International Standards Organization (ISO) and the International Electrotechnical Commission (IEC). The Sri Lankan government must formalize which test procedures are used to test the energy performance of products for the labeling (and later for the minimum energy standard) program. This would likely be a joint decision between SLSI, CEB, and the Ministry of Irrigation and Power. 
When the testing and labeling program is actually designed, the program design must include the following three essential testing elements:

1. Energy consumption test. A description of the energy consumption test that must be performed on the product in order to produce a valid energy consumption value to be shown on the energy label. This test should be based upon the agreed-upon test procedure as mentioned above. Depending on the type of appliance or equipment, the test could specify energy use per day, per hour, per month, or per cycle.

2. Other tests. A description of any other tests that must be performed to establish the product's capacity (e.g., $\mathrm{kW}$ cooling capacity for air conditioners, liters internal volume for refrigerators) or function/performance (e.g., a washing and drying index for dishwashers).

3. Tolerance. The Stakeholder Committee must specify rules to ensure that values reported by tests are within acceptable error bands. They must also specify rules for retesting and resolving any apparent differences in results.

\section{Step 2.6 Construct Test Facilities}

The amount of time to construct the test facilities will depend on a number of factors, including the commitment of CEB and the Stakeholder Committee, the availability of equipment, the delivery time of the equipment suppliers, the specific product, and whether the test facility is a greenfield project or will be retrofitted into an existing building. For example, the timing for the design, construction, and commissioning of an air conditioner test facility may take on the order of 12 to 18 months, although it is possible to speed up this timeline if the project is fast-tracked. If all goes well, some of the test facilities should be completed before the end of Year 2 .

\subsection{STEP 3. IMPLEMENT A PILOT VOLUNTARY LABELING PROGRAM}

The design and implementation of a voluntary energy labeling program should proceed in parallel with the development of testing capability and the development of framework legislation for mandatory standards and labeling.

SLSI and ECF have already issued a draft standard for a voluntary labeling program for fluorescent lamps ballasts. The standard specifies a simple test method for measuring the power loss of a ballast used with a fluorescent lamp. It sets out guidelines for the energy efficiency of ballasts used for 36/40W lamps and establishes a 5-star rating system. The draft standard describing the energy rating system lays out the following star rating system:

\begin{tabular}{|c|c|c|}
\hline $\begin{array}{l}\text { Range of active power } \\
\text { losses as \% of lamp } \\
\text { power }\end{array}$ & $\begin{array}{c}\text { Effective watt loss on a } \\
\mathbf{4 0 W} \text { lamp }\end{array}$ & Star Rating \\
\hline$\leq 15 \%$ & $\leq 6 \mathrm{~W}$ & $* * * * *$ \\
\hline $15.1-20.0$ & $6.0-8 \mathrm{~W}$ & $* * * *$ \\
\hline
\end{tabular}




\begin{tabular}{|c|c|c|}
\hline $20.1-25$ & $8.1-10 \mathrm{~W}$ & $* * *$ \\
\hline $25.1-35$ & $10.1-14 \mathrm{~W}$ & $* *$ \\
\hline $35.1-40$ & $14.1-16 \mathrm{~W}$ & $*$ \\
\hline$\geq 40 \%$ & $\geq 16 \mathrm{~W}$ & No stars \\
\hline
\end{tabular}

Note: All electronic ballasts shall be labeled with a 5-star rating

The draft standard raises a number of questions. One issue is the design of the label, which was developed by agency officials without consumer research to determine consumer/purchaser reaction to the label. Consumer research should be conducted to determine the effectiveness of the label design as well as the best format for reaching the target audience (e.g, on packaging, on the ballast, etc.) Another issue regards the stipulation that all electronic ballasts should be labeled with a 5-star rating. The quality of electronic ballasts varied widely, and in conversations with SLSI officials during our February 2000 mission, we strongly recommended that SLSI adopt the IEC performance standard for electronic ballasts and require that all electronic ballasts participating in the labeling program submit certification that the ballast meets this performance standard. ${ }^{1}$ We also recommended modifying the distribution of proposed label categories to reserve the top levels for models that will have the best available low-loss or electronic ballast technology. In response to a request from SLSI, IIEC prepared a memo providing recommendations for modifications to the draft standard. This memo was submitted to both CEB and SLSI on 24 March 2000. It is included in Appendix 5A of this report

Despite these reservations with the draft standard, we feel that the implementation of this voluntary labeling program should proceed without delay. The implementation of the program in Year 1 will provide important lessons for the stakeholders participating in the program. These lessons include the following:

- How effective is the ballast label design?

- How effective is the public awareness campaign?

- How well does the process work, and how can it be improved?

- What is the level of compliance with the labeling program (both in terms of manufacturer participation and the amount of fraud in the form of false data on labels)?

- What are the energy impacts of the labeling program?

- What has been the effectiveness of various agencies involved in the program?

All of these lessons will be critical to designing voluntary energy labeling programs for additional products and for eventually making the labeling program mandatory under Sri Lankan law.

\subsection{STEP 4. ENACT LEGISLATION TO SUPPORT MANDATORY LABELING AND STANDARDS}

The development of minimum energy performance standards is not within the scope of the proposed Appliance Testing and Labeling Program. However, international experience shows

\footnotetext{
1 International Electrotechnical Commission standard 929. See references.
} 
that minimum efficiency standards provide significant, reliable, and extremely cost-effective energy savings and are a natural complement to an energy labeling program. While the voluntary labeling programs are being implemented, the Stakeholder Committee should be working to develop and enact a regulatory basis for mandatory labeling and eventually minimum energy performance standards. Currently, it would be possible to use existing laws to empower the Department of Trade and Industry to require energy labels on specific electrical products. The labels could be mandated by DTI in the form of a Direction, under its mandate of the Consumer Protection Act. However, the Consumer Protection Act does not specify adequate enforcement mechanisms and fines for offenders, and it would be preferable to pass a new piece of legislation providing specific authority for the government to require mandatory energy performance labels and minimum energy performance standards.

While a number of countries have implemented voluntary energy labeling programs, experience suggests that, as a rule, mandatory programs work best. The reason is that within a voluntary program, manufacturers with poor energy ratings tend not to declare the energy consumption of their product. If many products with a poor energy rating have no labels, consumers are not able to avoid these products during the purchase process. Ultimately, labeling programs only work if all products are labeled and if consumers can easily distinguish between average, higher efficiency, and the highest efficiency products on the market.

In order to require comparative labels to be placed on all appliances, it is important to have specific legislative support. The legislation provides a clear legal mandate for a government agency to require manufacturers (or retailers) to place the labels on all affected products. It also implies strong political support. The legislation should also be drafted to provide a legal basis for minimum energy performance standards as well.

The most widely practiced approach to developing legislation for both labels and standards is to proceed in two stages. First, general legislation called "framework" legislation is introduced. This is followed by implementing regulations that are tailored to specific product types (e.g., lamps, refrigerators, etc.).

A framework law or decree should be issued that mandates standards for certain products, with provisions for expanding and revising the program later. The framework legislation should be generic and comprehensive rather than piecemeal in nature. It should develop a legal basis and authority for developing labels and/or standards without getting bogged down in technical details related to specific products. By empowering an implementing agency to develop product specific regulations at a later date, framework legislation avoids the need to return to the legislative assembly to seek approval for each new regulation. This has two benefits: (1) it passes responsibility for developing product-specific legislation to a body with greater technical competence; and (2) it removes a potentially serious cause of delay that can greatly reduce program effectiveness. Framework legislation should identify the main stakeholders and define their roles, responsibilities, and obligations with respect to the law. It should also designate a government agency as the "implementing agency" and give this agency the authority to issue product-specific standards. ${ }^{2}$ Later, implementing rules can be issued mandating energy labels or

${ }^{2}$ Two good examples of framework legislation are the EU Directive establishing a framework on energy labeling (92/75/EC) and the U.S. National Appliance Energy Conservation Act (NAECA) of 1987, updated in 1988. The EU 
minimum energy performance standards on a product-by-product basis, without the need for parliamentary action.

Framework legislation for labeling and standards should be completed and passed by the government by the end of Year 1.

\subsection{STEP 5. IMPLEMENT A LABELING PROGRAM}

Even before the framework legislation is in place, the Stakeholder Committee can begin to plan the expansion of the pilot labeling program into a multi-product program. We recommend that implementation of a voluntary program begin at the end of year 2, once the testing facilities have been completed and after the evaluation of the pilot labeling program for ballasts. The labeling program should become mandatory in year 3 or 4 , after one to two years of implementation of a multi-product labeling program. There are numerous advantages of beginning with a voluntary program. Two of the most important advantages are listed below:

- Beginning with a voluntary program facilitates acceptance of the program, allows manufacturers to gain comfort with the idea of energy labeling, and eventually increases the likelihood that they will support a mandatory program.

- Beginning with a voluntary program for one or a few products allows for a quick start to the labeling effort while additional test facilities are built and framework legislation is enacted.

\section{Step 5.1 Design the Overall Labeling Program}

Input from the Stakeholder Committee will be crucial to designing an effective labeling program. The process of stakeholder involvement can run in parallel to the development of the testing program and label design. Stakeholder interviews and meetings should be used to formulate and test the mechanics of how the program will operate. Some of the program design issues that need to be addressed include the following:

- Will the labeling program be voluntary or mandatory?

- Which agency will be the overall program lead?

- Which agency will manage product testing?

- Will private-sector laboratories be certified for testing?

- Who will issue the labels?

- How will monitoring and enforcement work?

- Who will evaluate the program, and how often?

- How can consumers be convinced that the label is credible?

- How can salespeople be recruited to promote the program?

- Will the labeling program pave the way for minimum efficiency standards?

Directive gives authority to the European Commission to issue product-specific energy labels following approval from a national panel of appointed specialists. The NAECA legislation empowers and obligates the U.S. Department of Energy to issue minimum energy-efficiency standards for energy-intensive tradable equipment when a specific set of criteria are met. 
Most of these questions can be answered through a process of group and individual meetings with key stakeholders. Eventually, if the stakeholder process is well managed, the private sector will buy into and ultimately support the program.

\section{Step 5.2 Establish a Certification Process}

There is a range of varying requirements regarding the certification of test results. Often, but not always, certification involves some form of registration or filing of test reports. Some countries require accredited test laboratories to be used, while others require full ongoing product certification. In fact, many countries allow manufacturers to self certify their products. The cost of the testing and certification program depends directly on the level of stringency of the process.

In some countries (e.g., in Australia and the U.S.), manufacturers have to submit test reports for the approval of an energy label. These reports are usually submitted as part of the process of product registration. An alternative approach is to require manufacturers to retain copies of the formal test reports until manufacturing of the model has ceased (or more commonly for a period of some years after manufacturing has ceased). The manufacturer is usually required to produce these test reports if there is a question regarding the validity of the label claims.

Below are some questions that need to be answered to establish a certification process that is both effective and acceptable to industry:

- Must the testing be conducted at one designated laboratory, or may any accredited laboratory be used?

- Will manufacturers be allowed to self-certify their products, with spot checks by an independent test laboratory?

- Will test results from accredited laboratories outside of Sri Lanka be accepted?

- How many units must be submitted for a test?

- What is the tolerance of the testing results?

- What provisions will there be for a manufacturer or a citizen to challenge the labeled energy performance of a product on the market?

- How does the implementing agency issue labels, and verify that these have been applied and sold into the market?

\section{Step 5.3 Design the Label}

The best way to design a label format is to conduct intensive consumer research prior to the implementation of the labeling program. Unfortunately, this is not normal practice. In most countries, labels have been developed by policymakers who seek little or no consumer input in the label design. One good example of using consumer research to develop an effective label design comes from India. We recommend using a phased approach including a baseline consumer survey, consumer focus groups and quantitative research. The research led to the 
development of a proposed energy label for India. ${ }^{3}$ This approach could be adopted for Sri Lanka.

The end result of the consumer research should be a label design that consumers can easily understand and appears to be effective. When designing the research, and ultimately deciding on the label format, it is useful to review the format of energy labels currently being used in countries around the world. Most countries have decided to adopt a label that is comparative with categories (see Table 5.1).

Table 5.1. Comparison of Label Types from around the World.

\begin{tabular}{|l|l|l|}
\hline Country & Type of label & Comments \\
\hline Canada & $\begin{array}{l}\text { comparison with } \\
\text { continuous scale }\end{array}$ & $\begin{array}{l}\text { Scale shows range of models in size class. } \\
\text { Energy use is the scale metric. }\end{array}$ \\
\hline United States & $\begin{array}{l}\text { comparison with } \\
\text { continuous scale }\end{array}$ & $\begin{array}{l}\text { Scale shows range of models in size class. On } \\
\text { old label, dollars was metric. On new label, } \\
\text { energy use is metric. }\end{array}$ \\
\hline Australia & $\begin{array}{l}\text { comparison with } \\
\text { categories }\end{array}$ & $\begin{array}{l}\text { Categories range from 1 to 6 stars; 6 stars is } \\
\text { most energy-efficient. }\end{array}$ \\
\hline South Korea & $\begin{array}{l}\text { comparison with } \\
\text { categories }\end{array}$ & $\begin{array}{l}\text { Categories range from 5 to 1; 1 is most } \\
\text { efficient. }\end{array}$ \\
\hline European Union & $\begin{array}{l}\text { comparison with } \\
\text { categories }\end{array}$ & $\begin{array}{l}\text { Categories range from G to A; A is most } \\
\text { efficient. }\end{array}$ \\
\hline Thailand & $\begin{array}{l}\text { comparison with } \\
\text { categories }\end{array}$ & $\begin{array}{l}\text { Categories range from 5 to 1; 5 is most } \\
\text { efficient. }\end{array}$ \\
\hline Philippines & $\begin{array}{l}\text { information only } \\
\text { label }\end{array}$ & $\begin{array}{l}\text { Labels only for air conditioner; show EER of } \\
\text { air conditioner. }\end{array}$ \\
\hline
\end{tabular}

\section{Step 5.4 Market and Promote the Program}

Placement of an energy label on a product is only the first step in attempting to influence the consumer purchase decision. Research has shown that education and promotion is necessary if the label is to have significant impact. A number of other related program measures can increase the effectiveness of an energy label. These include:

- retailer support for the program (hostile retailers can neutralize the impact of labels);

- government promotion of the program (e.g., annual efficiency awards);

- publication of lists of current models on the market - (e.g., a brochure and an Internet site that are easily accessible); and

- point-of-sale information and support.

In terms of marketing, it is important that consumers are subject to numerous consistent messages regarding energy efficiency -- not just as part of the energy labeling program but also

\footnotetext{
${ }^{3}$ International Resources Group. 1999. See references.
} 
in other, related energy programs that may be running in parallel. This reinforces a culture of energy efficiency among consumers and industry and helps to create an energy efficiency ethic within the country.

\section{Step 5.5 Police and Enforce the Program}

For a mandatory labeling program to be truly effective, there needs to be some mechanism to ensure that manufacturers, distributors and retailers comply. For a mandatory labeling program, it is usually necessary to have a policing and enforcement scheme to, first, assess the extent to which labels are not displayed on products and then to ensure that the level of non-compliance is minimized.

If an energy labeling program is to be credible with the public, it is necessary to ensure that claims made on any energy label are reasonable and accurate. This requires verification of the claims made on an energy label (in terms of capacity, performance and energy consumption, as applicable) through a process of independent testing. In a competitive market, much of the policing of this nature can be undertaken by market competitors. However, before legal actions regarding inaccurate claims can be instigated by governments, it is usual to confirm any such non-compliance through independent tests.

\subsection{STEP 6. IMPLEMENT MINIMUM EFFICIENCY STANDARDS}

We recommend that the analysis to establish minimum efficiency standards be conducted in year 3 or 4 of the program and that such standards should become effective 2 to 3 years after being approved by the government and publicly announced. This lag time will allow manufacturers and importers to adjust to the minimum standards and to improve their products to meet the new mandated efficiency levels.

\section{Step 6.1 Training in Standards Methodology}

This is an important capacity-building exercise. Once the institutional responsibilities have been assigned for the development of minimum energy performance standards, the responsible agency should assign key staff for a training course in all aspects of the methodology and practice of setting such standards. This training should be conducted with international experts with experience in the analysis, establishment, and implementation of minimum energy performance standards.

\section{Step 6.2 Conduct Detailed Assessment of Standard Impacts}

Before deciding to implement minimum energy performance standards, it is important to estimate the potential impact of energy standards by quantifying the environmental and monetary benefits. Our team has conducted a first estimate of the impact of an Appliance Testing and Labeling Program for a number of electrical end-use products. In order to justify a mandatory, 
minimum energy standard, however, it will be necessary to perform a more detailed assessment of the impact of different standard labels for each product. The assessment of the technical potential of a standard should be based on data describing:

- Current level of efficiency of products in the marketplace

- Expected level of efficiency possible

- Existence and characteristics of products manufactured domestically

- Existence and characteristics of products imported

- Existence and level of standards in neighboring countries

This assessment will involve collecting and interpreting new local data on consumer products and their use.

\section{Step 6.3 Issue Rules for Minimum Efficiency Standards}

Once the framework legislation has been enacted, then it will be possible for the government agencies to issue minimum energy performance standards for specific products. These will have to be justified by the standards impact assessment described above.

\subsection{STEP 7. MONITOR AND EVALUATE THE PROGRAM}

If a government is to maintain an energy efficiency labels and standards program over the long run, it will have to monitor the program's performance to provide guidance to adapt the program to changing circumstances and to demonstrate to funding agencies and the public that the expected benefits are actually being achieved. This will include assessments of the actual energy consumption of the regulated products, the level of consumer satisfaction for new energyefficient models, and the impact on individual manufacturers and their industry overall. Generally, it takes $5 \%$ to $10 \%$ of the total cost of the government's energy efficiency labeling and standards program to perform this task in a systematic and meaningful way. The evaluation will be an important tool for the participating government agencies to justify the program.

There are two main types of evaluation: process evaluation and impact evaluation.

\section{Process Evaluation}

Process evaluation is primarily qualitative in nature and measures how well the program is functioning. Unfortunately, process elements are sometimes seen as less important by policymakers. In reality, these elements are critical to the implementation and success of a program. Process elements include:

- assessing consumer priorities in purchasing an appliance;

- tracking consumer awareness levels;

- monitoring correct display of labels in retailers; 
- measurement of administrative efficiency (eg registration times etc.); and

- checking and verifying of manufacturer claims (maintaining program credibility).

\section{Impact Evaluation}

Impact evaluation is used to determine the energy impact of the program. The impact data can be used to determine program costs and benefits as well as greenhouse gas emission impacts. Impact evaluations can also assist in stock modeling and end-use (bottom up) forecasting of future trends. Impact elements include:

- influence of the label on purchase decisions;

- tracking of sales weighted efficiency trends; and

- energy and demand savings.

Impact evaluation can be very difficult to accurately determine, especially for a labeling program. One of the fundamental problems is that once a program such as energy labeling has been in place for some period, it becomes increasingly difficult and hypothetical to determine a "base case" against which to compare the program impact.

It is important to plan both the evaluation before an energy labeling program is implemented. Data collection strategies can then be built into the program design and operation. It is simpler, more reliable, and less expensive to plan and collect data during a program's operation; retrospective data collection is more difficult, more expensive, and sometimes impossible.

\subsection{STEP 8. REVISE AND UPDATE LABELS AND STANDARDS}

Good test procedures, labels and standards require periodic review and update of procedures to accommodate new technology and changing use patterns. The periodic review allows the government to adjust test procedures, redesign labels, and "ratchet" the stringency of standards upwards as new technology emerges. Whether the intent is to refine test procedures to reflect changing use patterns, redesign labels to better inform consumers, refine test procedures or standards to minimize circumvention of the standards by some manufacturers, or simply take advantage of new opportunities for enhanced energy efficiency, periodic review is crucial to an effective labeling and standards program. Review cycles in countries with such programs typically range from three to 12 years, depending on the product and national politics. We recommend that CEB plan to review and update the label and/or minimum energy standard for each product a minimum of every five years.

\subsection{ESTIMATED PROGRAM COSTS}

This section provides estimates of the costs for developing the labeling program office and for the consulting assistance necessary to advice the Sri Lankans and provide technical assistance 
during program development during years 1 through 3 . The capital and recurring costs associated with designing, building, and operating the test laboratories are provided separately under Task 6.

\section{Costs for the Labeling Program Office}

We divided the costs of establishing the labeling program office into initial (or capital) costs and annual recurring costs (see Table 5.2). The initial costs include:

- the cost of computers for staff;

- facility costs, which include the cost of a build-out or modifications to an existing building, such as the addition of climate control; and

- vehicle costs, which include the cost of a program vehicle for field work, such as visiting manufacturers, test laboratories, etc.

The annual recurring costs include:

- The costs of staffing, which is based on local salary rates provide by CEB and an assumption of 10 full-time staff members.

- Operation costs, such as utilities, miscellaneous overhead, etc. Based on input from CEB, we assumed that operation costs would be approximately $10 \%$ of staffing costs.

Table 5.2. Cost Budget for the Labeling Program Office

\begin{tabular}{|c|c|}
\hline Cost Item & Amount (US\$) \\
\hline \multicolumn{2}{|l|}{ Initial costs } \\
\hline Support equipment & 20,000 \\
\hline Facility(building) & 20,000 \\
\hline Vehicle & 30,000 \\
\hline Sub-total Initial & 70,000 \\
\hline \multicolumn{2}{|l|}{ Annual recurring costs } \\
\hline Staffing & 32,571 \\
\hline Operation & 3,257 \\
\hline Sub-total annual recurring & 35,829 \\
\hline
\end{tabular}

\section{Costs for Consulting Assistance}

We based the estimates of the costs for consulting assistance directly on the steps outlined in the Action Plan in this chapter. The table shows specific technical assistance that will be required for each line item in the Action Plan. There is a brief description of the nature or scope of each consulting assignment. In developing these estimates, we made the following assumptions: 
- We assumed a "Base Case" and a "High Case." The Base Case assumes the cost for carrying out each consulting assignment across four test laboratories (i.e. four products). The High Case assumes that the assignment covers a total of six test laboratories.

- The total cost of a consulting assignment, including labor, travel, and other direct costs will be $\$ 25,000$ per month.

- The time to manage and coordinate this consulting assistance would be $15 \%$ of the total person days.

- To facilitate and expedite the purchase of test lab equipment, we assumed that the overseas equipment would be procured by a procurement agent. We estimated that the procurement fee for be $5 \%$ for all test lab equipment.

- Step 4, the development of supporting legislation, is critical to laying a legal basis for the entire program. We have budgeted for a High Level Parliamentary Workshop in Year 1 to build support among lawmakers for the importance and benefits to Sri Lanka of energy labeling and standards.

- For Step 6, we assumed that the consultants would work with CEB to develop a workshop on Minimum Efficiency Performance Standards Methodology and Experience. Although the actual development of standards is not within the scope of this program, we believe that it is essential to train Sri Lanka policymakers in standards methodology and to lay the groundwork for the development of standards. Only with eventual mandatory minimum efficiency standards will the long-term benefits of the Sri Lanka Appliance Testing and Labeling program be "locked in" through complete and irreversible market transformation. 
Table 5.3 Budget for Consulting Assistance to Sri Lanka Appliance Testing and Labeling Program

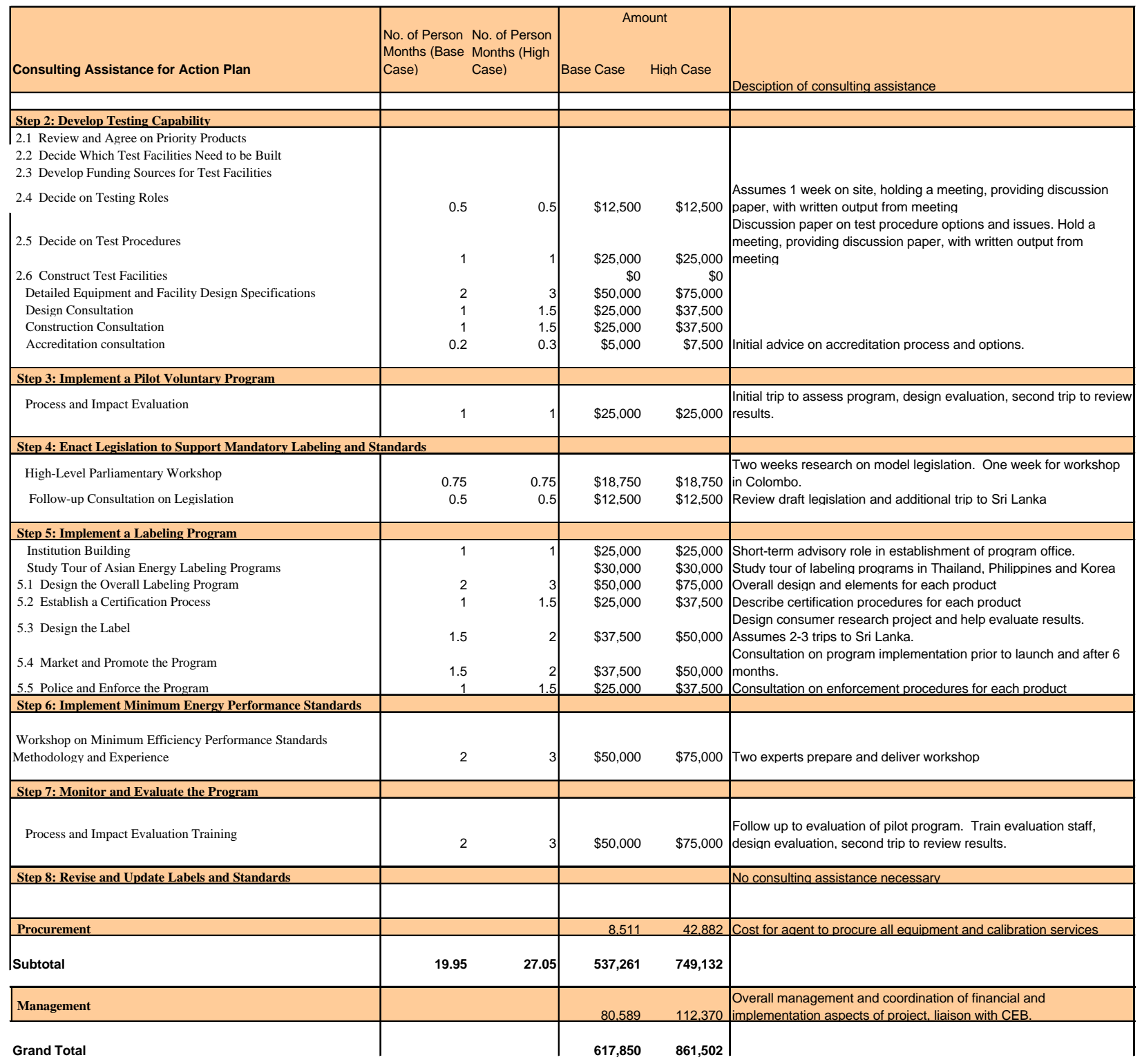




\subsection{REFERENCES}

International Electrotechnical Commission (IEC). A.C.-Supplied Electronic Ballasts for Tubular Fluorescent Lamps - Performance Requirements.

International Resources Group. 1999. "Appliance Efficiency Market Research and Label Development in India. Part III: Final Label Preference Research." Conducted by the U.S. Agency for International Development by the International Resources Group and Taylor Nelson Sofres Mode. Delhi, India. September. 


\subsection{APPENDIX 5A: MEMO ON DRAFT STANDARD FOR BALLAST LABELING PROGRAM}

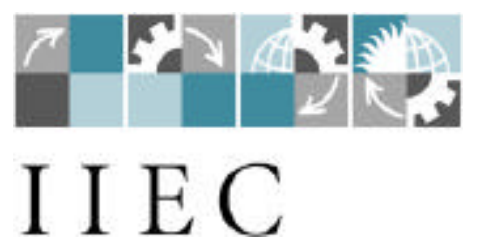

Affiliated with the Civil Engineering Research Foundation
Asia Regional Office

Racquet Club Building

8 Sukhumvit Soi 49/9, Wattana

Bangkok $10110 \bullet$ THAILAND

Tel: $+66(2) 3810814,7126057-8$

Fax: $+66(2) 3810815$

E-mail: iiecasia@loxinfo.co.th

Web: www.cerf.org/iiec

Partners for Sustainable Energy and Environmental Solutions

Date: 24 March 2000

To: M.S. Jayalath, Deputy General Manager for DSM, CEB

Ms. J. Dewasurendra, SLSI

From: Peter du Pont, Ph.D., Managing Director, Asia Operations, IIEC lete T. duq

Re: Recommendations on Fluorescent Ballast Labeling Program

This memo provides recommendations and input to the Draft of SLS 1200:1999, the draft standard for a Start Rating and Labeling System for Fluorescent Ballasts. Its follows up on a discussion that Noel Priyantha of CEB and I had with Ms. Dewasurendra this morning regarding the specifications and draft standard for the proposed voluntary energy labeling program for fluorescent lamps.

IIEC recommends that the top tier of the rating system, 5 stars, be reserved exclusively for electronic ballasts that meet IEC standard 928 for safety and IEC standard 929 for performance of electronic ballasts. Currently, only a very small percentage $(<1 \%)$ of ballasts on the market are electronic. Reserving the 5 star rating for electronic ballasts will provide an incentive for importers and local manufacturers to import and sell electronic ballasts, which offer significant energy and performance benefits compared to magnetic ballasts. IIEC recommends specific language requiring that electronic ballasts receive the IEC certifications in order to qualify for the 5-star rating. The IEC certification will solve the issue of safety and quality, ensuring that only quality electronic ballasts can participate in the labeling program.

A second issue regards the classifications for the 1-4 star rating categories. Broadly speaking, an energy rating classification system should be designed in relation to the distribution of efficiencies of models on the market. The ratings should allow for gradual improvement of models in the market to meet the higher level of efficiency. In the draft standard reviewed by IIEC, the proposed power loss ratings would make it nearly impossible for importers/manufacturers to achieve either the 3-star or 4-star rating. Data on testing of new magnetic ballasts provided by SLSI indicates that standard magnetic ballast are in the range of 10-12 watt loss ( $\sim 25 \%$ active power loss for a 40 -watt ballast). More efficient ballasts are available in the range of $\sim 6-8$ watt loss $(\sim 15-20 \%$ active power loss $)$. In Thailand, EGAT has set 
the cutoff level for a "low-loss ballast at below 6 watts loss. IIEC believes that for this pilot program, a target of less than 6 watts loss is a reasonable goal for magnetic ballasts.

In light of the above information, IIEC recommends that the draft standard be modified to achieve the following goals:

- The worst models on the market achieve a 1-star rating;

- current standard models achieve a 2-star rating;

- more efficient models available on the market achieve a 3-star rating;

- the best low-loss models achieve a 4-star rating; and

- electronic ballasts achieve a 5-star rating.

In line with the above objectives, IIEC recommends the following revised table of star ratings for fluorescent ballasts.

Proposed Revision to "Table 1 - Star Rating for ballasts used for 36/40 W fluorescent lamps."

\begin{tabular}{|l|l|l|c|}
\hline $\begin{array}{l}\text { SI. } \\
\text { No. }\end{array}$ & $\begin{array}{l}\text { Percentage range of active power } \\
\text { loss in the ballast }\end{array}$ & Watts loss & Star rating \\
\hline 1 & $\begin{array}{l}\text { Electronic ballasts certified to IEC standard 928 (safety) } \\
\text { and 929 performance for electronic ballasts. }\end{array}$ & $\leq * * * * *$ \\
\hline 2 & $\leq 15 \%$ & $6.1-8 \mathrm{~W}$ & $* * * *$ \\
\hline 3 & $15.1-20 \%$ & $8.1-10 \mathrm{~W}$ & $* * *$ \\
\hline 4 & $20.1-25 \%$ & $>10 \mathrm{~W}$ & $* *$ \\
\hline 5 & $>25 \%$ & & $* * *{ }^{2}$ \\
\hline
\end{tabular}

Please feel free to contact me at IIEC if you have any follow-up questions regarding these recommendations. 


\subsection{APPENDIX 5B: IMPLEMENTATION TIMELINE}

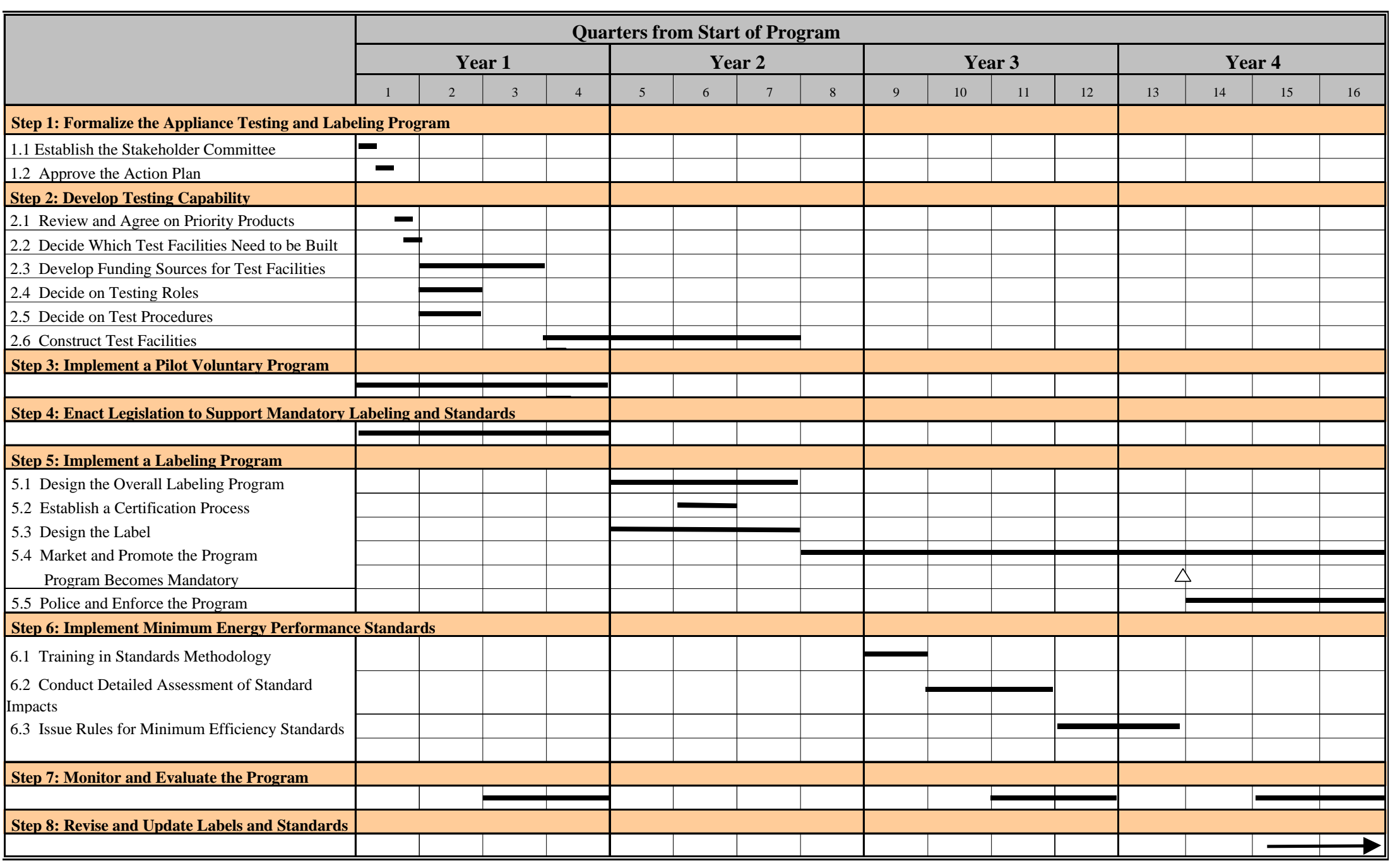




\section{Task 6 - Appliances and Lighting Test Procedures and Instrumentation}

\subsection{INTRODUCTION}

Task 2 of this report, analyzed which products had the greatest potential to save energy if Sri Lanka had energy labels, minimum standards or some other energy efficiency program. The requirements to test the products below where evaluated in Task 6. Costs to start up and administer testing facilities are shown in Table 6.1.

Table 6.1 Test Laboratory Cost Summary

\begin{tabular}{|c|c|c|}
\hline Appliance & Start Up Costs & Recurring Costs \\
\hline $\begin{array}{c}\text { Lighting Flourescent Lamp Ballasts } \\
\text { \& Lighting, CFLs }\end{array}$ & $\$ 166,094$ & $\$ 13,303$ \\
\hline Refrigerator & $\$ 184,320$ & $\$ 12,111$ \\
\hline Air Conditioners: Room \& Mini-split & $\$ 269,634$ & $\$ 20,979$ \\
\hline Motors & $\$ 301,200$ & $\$ 23,626$ \\
\hline 4 Lab Totals & $\$ 921,248$ & $\$ 70,019$ \\
\hline Ceiling Fans & $\$ 69,110$ & $\$ 6,807$ \\
\hline Televisions & $\$ 66,075$ & $\$ 5,208$ \\
\hline 6 Lab Totals & $\$ 1,056,433$ & $\$ 82,034$ \\
\hline Pumps & Overview of standards only (no costs) \\
\hline
\end{tabular}

In the following sections of Task 6, each of the above appliances or lighting is discussed in greater detail. The general approach is to provide some background information, present existing test procedures used, list the requirements of a test procedure and select and cost the instrumentation. These sections are discussed below.

\section{Introduction}

This section includes the countries from which a particular appliance is imported. This information may be relevant in harmonizing test procedures. If the export country used a certain test procedure, Sri Lanka may want to take that under consideration to reduce the testing burden of the supplier. 


\section{Test Procedure Standards}

Information on test procedures used around the world is presented in tabular form. Many standards are variations of internationally accepted standards.

\section{Test Procedure Requirements}

The requirement of instrumentation and equipment needed to test to a given test procedure is given.

\section{Equipment Cost}

The instrumentation listed in the tables is an example of what might be used in order to estimate the equipment costs. However, instrument prices change over time and new products are introduced. There may be some variation in product and/or prices over time. Time did not permit a complete comparison of equipment prices and capabilities for the equipment. Recognizing this, other brands or models may be substituted for the equipment listed.

\section{Training}

Sources for training include:

1. Vendors of the instrumentation and turn-key test facilities

2. Laboratories, e.g., ITS and other existing appliance efficiency laboratories

3. Independent expert consultants

4. Accreditation and proficiency testing bodies

Standardized proficiency testing is available from international bodies. This include courses or reference material for self study. An example of a proficiency test organization is: NAPT (National Association for Proficiency Testing). They offer testing for any one discipline at $\$ 495$; see there web site for their fee schedule (package discounts are available), www.proficiency.org/feeschedule.htm.

\section{Accreditation}

There are two primary accreditations that apply to appliance testing laboratories:

(1) ISO/IEC Guide 25, and

(2) ISO/IEC Guide 58.

Guide 25 will become part of a ISO/IEC standard called ISO/IEC 17025. This will be enacted by the end of the year in 2001. For accreditation associations see the section on Resources for additional information.

\section{Standard Purchase}

The cost of obtaining test procedure standards and supporting literature required for training. The cost of purchasing existing standards from standard setting organizations is estimated to be approximately $\$ 200$ per year. Many test procedures can be purchased over the internet. See the Resource section for sources to buy standards. 


\section{Facility Cost (land, buildings, site improvements)}

This is a difficult cost to determine and can vary greatly depending on whether or not existing land or an existing building is used. Even when an existing building can be used, renovations are improvements are probably necessary to make it suitable for a test laboratory. Several possible testing sites were visited in Sri Lanka during February 2000. These are listed below with accompanying comments. One of the considerations is the availability of space, the location of the laboratory relative to the port of Colombo and the airport.

(1) CEB Central Garage - this location may become available should utility restructuring take place. It has room and existing buildings but would need improvements and temperature controlled buildings to be suitable for a test laboratory. This may be a good choice for a refrigerator or air conditioning test laboratory.

(2) CEB Training Facility - has land for additional buildings, well landscaped but access road needs improvement. This site is currently being used to conduct training in electrical subjects and to calibrate electrical $\mathrm{kWh}$ meters.

(3) SLSI - Sri Lanka Standards Institute in Colombo, has an existing laboratory used to test lighting and ballasts. Does not appear to have room for expansion.

(4) ITI - this facility in Colombo has existing instrumentation for temperature and power measurement

A place holder value of $\$ 20,000$ is currently entered into the cost spreadsheet. The actual cost will depend on whether or not existing space is used or modified or if a new facility must be built. These costs are to be considered very approximate values, basically, place holders until more accurate information on buildings and land is gathered.

\section{Staffing Costs}

The number of engineers and technicians needed for testing an appliance was estimated. The cost of an engineer with overhead included was assumed to be $\$ 10,000$; for a technician $\$ 6,000$. From information on wages in India and from job employment classified advertising at a University in Sri Lanka, these may be somewhat overestimated. It is understood that personnel costs can vary greatly, depending on experience, and employer. There are some limits as to the flexibility government agencies have on setting salaries.

\section{Operation Costs}

This cost was estimated by using $10 \%$ of the staffing costs. This figure includes recurring costs such as utility (electricity) and maintenance costs.

\section{Calibration}

Most instruments need to be calibrated at least once a year. There are several options for doing this. They can be calibrated by a laboratory in Sri Lanka, instruments can be sent back to the manufacturer for calibration, or they can be calibrated by an accredited laboratory in another country. Calibration cost were estimated to be $5 \%$ of the equipment costs. Some intermediate calibration can be done by purchasing calibration equipment and using this primary instrument to 
calibrate secondary instruments.

\section{Resources}

In addition to the sections on individual appliances, a section is also provided that lists sources for further information. 


\subsection{LIGHTING - BALLASTS}

\section{Introduction}

Sri Lanka has mostly single lamp ballasts equipped with a starter. Often these are connected to T8 lamps in 2 foot and 4 foot lengths ${ }^{1}$. There is no domestic production of ballasts. Ballasts are imported mostly from China (52\%), Hong Kong (14\%), and Germany, S. Korea \& U.S.A. with about $7 \%$ each. Flourescent lamp ballasts are of two basic types: 1) ferromagnetic and 2) electronic.

\section{Test Procedure Standards}

Countries having ballast standards include: Canada, Korea, Indonesia, Malaysia, Philippines, Chinese Taipei, Thailand, USA [from Workshop on Setting-Up and Running an Energy

Performance Testing Laboratory, July 1999]

Table 6.2 Ballast Test Procedure Standards

\begin{tabular}{|c|c|c|}
\hline Standard & Equivalent to or based on & Country \\
\hline SLSI 1150 & based on IEC & Sri Lanka \\
\hline CAN/CSA-C654-M91 & U.S. DOE Std. & Canada \\
\hline $\begin{array}{l}\text { KS C8102 [ferromagnetic] } \\
\text { equivalent to } \\
\text { KS C8100 [electronic] } \\
\text { [not in English] }\end{array}$ & $\begin{array}{l}\text { JIS C8108, } \\
\text { based on IEC60920(safety), } \\
\text { IEC60921 (performance) } \\
\text { IEC60929 }\end{array}$ & Korea \\
\hline MS 141 & $\begin{array}{l}\text { IEC60921 for ferromagnetic } \\
\text { iec60929 for electronic }\end{array}$ & Malaysia \\
\hline PNS 12-2:1996 & IEC60921 & Philippines \\
\hline $\begin{array}{l}\text { CNS3888-85 } \\
\text { CNS927-96 }\end{array}$ & $\begin{array}{l}\text { IEC60920(safety), } \\
\text { IEC60921 (performance) }\end{array}$ & Chinese Taipei \\
\hline TIS23-2521 & $\begin{array}{l}\text { IES } 82 \text { [withdrawn] } \\
\text { now IEC60921 }\end{array}$ & Philippines \\
\hline 10CFR430 Sub Part B, App Q & ref. to ANSI C82.2 & USA \\
\hline GB/T 15144 & $\begin{array}{l}\text { similar to that of the US. Japan and Korea both use } \\
\text { similar approaches although some of the details are } \\
\text { different }\end{array}$ & China \\
\hline
\end{tabular}

${ }^{1}$ Based on residential survey discussed in Task 2 


\section{Discussion of Test Procedures}

There are three main groups of ballast performance test procedures:

1. IEC60921, IEC60929 and related standards

2. North American standards

3. European standard (EN50294)

The North American and European standards are similar with respect to general methodology. They are applicable to any type of ballast and because the measurement of lamp power is not necessary, only total circuit power and lumen output is required. They also allow the comparison between magnetic and electronic ballasts. All of the standards require reference lamps and ballasts. Australia and New Zealand are also developing standards with the same basic methodology as the North American and European standards. A good summary of the differences between the test procedures can be found in the reference: APEC Colloquium on Technical Issues of Minimum Energy Performance Standards Oct. 1999, Seoul, Korea. A few comments on the various standards are given below.

It would be desirable to use a standard that measures input to the ballast and relative output (compared to a reference ballast) to a reference lamp. This way efficacy can be compared for both magnetic and electronic ballasts. In addition, a harmonic analyzer would be useful to measure other properties of electronic ballasts.

\section{IEC}

The efficacy of ballasts is not a performance variable that is defined or specified in IEC60921 or IEC60929. However, the standard does specify a method for the determination of relative light output using a reference lamp. The measure of ballast watts loss is only applicable for those ballast types where the lamp power can be directly determined, such as ferromagnetic types \& instant start. Lamp power cannot be directly determined for electronic, high frequency ballasts or rapid start ballasts.

\section{European Norm}

European EN50294-1988 - Ballast input power method. Australia and New Zealand are developing local versions of this standard which is similar in concept to the North American (U.S. DOE). In these standards both total circuit input and lumen output or relative lumen output is needed to determine ballast efficacy. This has not yet introduced as a IEC standard.

\section{US DOE standard}

BEF (relative light output divided by total power) is used in North America. Other countries use Lumens per Watt. In each case the concept is the same, the wattage for a normalized light output. U.S. conditions are externally referenced to ANSI C82.2. Reference lamps and ballasts are defined in the standard. 


\section{Current SLSI Standard}

Sri Lanka is currently considering the voluntary labeling of ballasts. The current test procedure applies to ferromagnetic ballasts only. Basically, a current of $360 \mathrm{~mA}$ is supplied to the ballast and the power input in watts is measured. The efficiency is measured as the wattage loss per ballast. The current standard, SLS1150 Ballasts for tubular flourescent lamps, is based on the IEC test procedures and simplified for use in Sri Lanka. Presently, only magnetic ballasts can be tested by this method. SLSI is interested in obtaining a reference ballast and lamp per IEC standards $929 \& 928$. These standards are for the performance and general and safety requirements for electronic ballasts. They need a reference ballasts and lamps for 20 watt ( $2 \mathrm{ft}$ ) and 40w (4ft) lamps.

\section{Table 6.3 U.S. DOE's Ballast Test Procedure Requirements}

\begin{tabular}{|c|c|c|c|}
\hline Instruments & Accuracy & Tolerance & Comments \\
\hline $\begin{array}{l}\text { Temperature } \\
\text { Measuring Device }\end{array}$ & & $\begin{array}{l}\text { When ballast testing } \\
\text { involves the measurement } \\
\text { of lamp characteristics the } \\
\text { measurements shall be } \\
\text { made with the lamp at an } \\
\text { ambient temperature of } \\
25 \mathrm{C}+/-1 \mathrm{C} \text {. Preferred } \\
\text { tolerance of }+/-0.5 \mathrm{C}\end{array}$ & $\begin{array}{l}\text { This temperature to be measured at a point not } \\
\text { more than } 3 \mathrm{ft}(914 \mathrm{~mm}) \text { form the lamp and at } \\
\text { the same height. } \\
\text { Ballasts are operated at room temperature. }\end{array}$ \\
\hline Ammeter & $\begin{array}{l}+/-0.5 \%, \text { up to } \\
800 \text { cycles }\end{array}$ & & $\begin{array}{l}\text { Instruments connected in parallel with the } \\
\text { lamp shall never draw more than } 1 \% \text { of the } \\
\text { rated lamp current. }\end{array}$ \\
\hline Voltmeter & $\begin{array}{l}+/-0.5 \%, \text { up to } \\
800 \text { cycles; } \\
\text { resistance shall be } \\
10 \text { megohms } \\
+/-10 \%\end{array}$ & & $\begin{array}{l}\text { In no case shall the voltmeter draw a greater } \\
\text { current than } 1 \% \text { of rated lamp current. }\end{array}$ \\
\hline Watt meter & $\begin{array}{l}+/-0.75 \%, \text { up to } \\
800 \text { cycles and } \\
\text { down to at least } \\
50 \% \text { power factor }\end{array}$ & & \\
\hline Transformers & & & $\begin{array}{l}\text { Transformers should be high quality and have } \\
\text { good regulation (less than 5\%) and have a } \\
\text { current capacity several times the actual } \\
\text { current required. }\end{array}$ \\
\hline
\end{tabular}

\section{Comments}

Performance \& Quality Requirements: For ballasts, especially electronic ballasts, the quality and durability of the ballast is as important as the efficacy. If the ballast is efficient but does not last very long, it will give the efficiency label a bad reputation. 
Reference ballast from components: Some equipment can be used in all of the above standards. For example, a harmonic analyzer. If a reference ballast is composed of discrete components, e.g., variable resister, variable inductor, then it can be tuned to the specifications of any specified reference ballast. This would be the most flexible option but requires more knowledge and training.

\section{Cost of a Ballast Testing Facility}

The cost of a ballast testing facility is provided two ways:

- $\quad$ the facility requirements based on U.S. DOE standards but also providing the equipment useful for any ballast standard, and

- $\quad$ the costs for an overall lighting test facility including ballasts and lamps as given in general specifications by ITS.

Table 6.4 Ballast Testing Instrumentation and Equipment

\begin{tabular}{|lllc|}
\hline \multicolumn{1}{|c}{ Instrument/Equipment } & \multicolumn{1}{c}{ Brand } & \multicolumn{1}{c|}{ Specification } & \multicolumn{1}{c|}{$\begin{array}{c}\text { Price } \\
\text { U.S. \$ }\end{array}$} \\
\hline $\begin{array}{l}\text { Reference Ballast } \\
\text { (variable linear reactor) } \\
\text { (two - for 2 ft and 4 ft } \\
\text { lamps) }\end{array}$ & $\begin{array}{l}\text { WPI Industrial } \\
\text { Technology - VLR-2 }\end{array}$ & $\begin{array}{l}\text { to meet requirements of ANSI C82.2- } \\
1984 \text { or IEC 928 \& 929 or as } \\
\text { specified in alternate standards }\end{array}$ & (\$2,376 each) \\
V-A-W (Power Analyzer) & Voltech PM3300 & $\begin{array}{l}\text { 0.05\% accuracy; includes } \\
\text { measurement of harmonics, PF }\end{array}$ & $\$ 10,000$ \\
Voltage regulators & Stabiline Voltage & max. watts $=80$ \\
& $\begin{array}{l}\text { Regulator, model } \\
\text { PPCX52110 }\end{array}$ & & $\$ 215$ \\
Variable transformer & $\begin{array}{l}\text { Warner Electric } \\
\text { 10C-12 }\end{array}$ & & $\$ 93$ \\
Photometer & Tektronix J18 & & $\$ 2,639$ \\
$\begin{array}{l}\text { Thermocouple reader } \\
\text { (temperature meter) }\end{array}$ & Omega MDSS41-TC & & $\$ 820$ \\
$\begin{array}{l}\text { Thermocouple wire }-1000 \\
\text { ft. roll }\end{array}$ & Omega TT-T-24SLE & 24 AWG type T wire & $\$ 375$ \\
\hline
\end{tabular}

Total Equipment Costs

Other costs below include CFL lighting laboratory costs. Equipment costs for CFL testing is outlined in the next section. 
- $\quad$ personal computer for keeping records, writing reports, etc.

Training Costs

$\$ 12,000$

- $\quad$ visit to an existing ballast test facility, for example ITS

- consulting costs by ITS $\$ 1500$ for engineer, $\$ 1300$ for technician

(special discounted rates may apply is training is performed by equipment vendor)

Accreditation Costs

- NVLAP accreditation

- $\quad$ NARDA, A2LA or other

Standard Purchase

Facility Requirements

- A climate controlled room; keep room temperature at $25 \mathrm{C} \pm 1 \mathrm{C}$ (preferred tolerance of $\pm 0.5 \mathrm{C}$ ); this may be achieve in different ways or may be part of an existing laboratory environment. Possible room conditioning equipment would include a PID temperature controller connected to a 3-way hydronic valve and a fan coil with hot and chilled water coils.

- Workbench for ballast and lamps and bench top watt, volt \& amp meter

- $\quad$ Personal computer for reports

- $\quad$ Office space for record keeping and testing log

- $\quad$ Possible siting: general laboratory space (SLSI or CEB?)

- $\quad$ For US DOE; non-reflective surrounding surfaces, no drafts

Staffing Requirements $\$ 7,371 / y r$

- $\quad$ three full time technicians with electrical training

- $\quad$ one supervising engineer

Operation Costs

Calibration Services

\section{TOTAL COSTS}

- $\quad$ Start Up (Lighting Ballast Only) $\ldots \ldots \ldots \ldots \ldots \ldots \ldots \ldots \ldots \ldots \ldots \ldots \ldots \ldots \ldots \ldots \ldots, 0 \ldots 4$

- $\quad$ Recurring (Ballast \& CFLs) 


\section{Capacity to test}

Several ballast can be testing in one day. One testing set-up per ballast type tested should provide sufficient testing capacity.

\section{ITS RECOMMENDATIONS ${ }^{1}$}

A properly setup testing laboratory would require approximately 65 square meters. This would include storage space, lamp conditioning room, automated test stand, laboratory benches for manual tests etc.

\section{Lighting (Ballast's, Fluorescent Lamps, Compact Fluorescent Lamps)}

\section{Forward}

Lighting products generally are reviewed as a combined effort. Ballast's, fluorescent lamps (FL's), and compact fluorescent lamps CFL's generally are tested within the same laboratory and using similar equipment were possible. However, careful consideration must be made when selecting testing equipment because typical magnetic ballast's and electronic ballast's differ greatly in construction. Due to the difference the test methods required and test setup's differ as well. CFL's are typically comprised of an electronic ballast as part of their construction.

In the case of Ballast's and Fluorescent Tubes, testing requirements to meet the needs of any proposed certification requirements may not necessarily need all capability suggested in the referenced test standards. It some cases only those measurements related to performance and energy efficiency are included in the procedural guide. For example, only portions related to power consumption, efficiency and light output may be the only sections required for a suitable certification program. This can save time and money when implementing an energy efficiency program when other mandatory safety programs and manufacturer quality programs exist in other forms.

\section{CFL's}

From previous experience and due to high concern for product quality, it is imperative that the test standard and test procedures adequately measure performance, reliability and life span for CFL's. Prospective certification programs may require additional tests and equipment for demonstrating the quality of these products.

\section{Proposed Capabilities}

Proposed capabilities include necessary space, equipment and manpower to perform testing of Ballast's, FL's, and CFL's.

\section{Equipment}

A properly setup testing laboratory would require approximately 65 square meters. This would include storage space, Lamp conditioning room, automated test stand, laboratory benches for manual tests etc. 
Necessary pieces of equipment include:

- $\quad$ Power analyzers

- Volts, Amps, Watts, Power Factor

- CFL's require Harmonic Analysis

- Digital Oscilloscope

- $\quad$ Possibly required for proper measurement of peak lamp current

- $\quad$ Lamp Conditioning Rooms

- For stable temperature control of reference/test lamps

- $\quad$ Provide Draft-Free air near reference/test lamps

- $\quad$ Automated Test Stands

- For relative light output measurements

- Electrical properties of lamps

- Electrical properties of ballast's

- Integrating Sphere

- $\quad$ For direct measurements of integral CFL light output

\section{Staffing}

Minimum staffing requirements for one test facility capable of performing from $500-600$ tests per year for all product groups, including Ballast's, Fluorescent Lamps, and Compact Fluorescent Lamps are as follows:
- Department Manager
- Department Secretary
- $\quad$ (1) Test Engineers
- (3) Test Engineering Technicians

Note: Department Manager and Department Secretary may be shared when multiple facilities are specified. Certainly across the different product areas defined above. As capability is expanded, sharing of technicians may not be feasible due to the very hands on nature of this testing and relatively short test time. Number of technicians to perform tests is heavily dependent on amount and type of testing required. Specified technicians above are for testing related to a certification program. Additional safety or quality tests may require additional technicians and equipment.

\section{Cost}

Estimated costs for lighting test laboratory equipment.
- $\quad$ Power analyzers
(3) Total US\$20,000 - $\$ 30,000$
- Digital Oscilloscope
(1) Total US $\$ 15,000-18,000$
- $\quad$ Lamp Conditioning Rooms
(3) Total US $\$ 150,000-\$ 200,000$
- $\quad$ Semi-Automated Test Stands
(3) Total US $\$ 225,000$ - $\$ 375,000$
- Integrating Sphere
(1) Total US $\$ 75,000-\$ 125,000$

Total Equipment Costs $\ldots \ldots \ldots \ldots \ldots \ldots \ldots \ldots \ldots \ldots$ US $\$ 485,000-\$ 748,000$ 
Considerable time and cost could be avoided if procedural guides were developed to define testing requirements for the certification program. Simply calling out an existing test standard may imply that all tests within must be performed in order to comply. It should be noted however that in the case of CFL's it has been determined previously that the need for additional testing may be required to identify low quality products.

\section{Additional Detail for Ballast Test Procedure Standards ${ }^{2} 3$}

The summary of test procedures standards below is based on the report Review of Energy Efficiency Test Standards and Regulations in APEC Member Economies, July 1999 with additional information taken from the actual standards.

Table 6.5 Ballast Test Procedure Standards

\begin{tabular}{|c|c|c|}
\hline Country & Type of Standard & Comments \\
\hline Australia & NA & \\
\hline Brunei Darussalam & NA & \\
\hline Canada & $\begin{array}{l}\text { CAN/CSA-C654- } \\
\text { M91 }\end{array}$ & $\begin{array}{l}\text { Mandatory labeling. The test procedures for FLUORESCENT LAMP } \\
\text { BALLASTS is essentially equivalent to that required for USA. } \\
\text { Reference lamps and ballasts systems are defined in the standard. The } \\
\text { lumen output of a test ballast with an appropriate reference lamp is } \\
\text { determined under stabilized conditions. The ballast efficacy factor } \\
\text { (BEF) is determined as the ratio of the relative light output of the test } \\
\text { ballast/reference lamp combination (in comparison with the reference } \\
\text { lamp/ballast system) divided by the total system power. Minimum BEF } \\
\text { values as well as a number of other performance requirements are } \\
\text { specified. No minimum ballast lumen factor is specified in the standard. } \\
\text { The standard is applicable to } 4 \text { types of fluorescent lamp ballasts: } \\
\text { 40T12 rapid start; } 96 \mathrm{~T} 12 \text { rapid start; } 96 \mathrm{~T} 12 \text { instant start; and F32T8 } \\
\text { rapid start, all intended to operate at } 60 \mathrm{~Hz} \text { and either } 120 \mathrm{~V}, 277 \mathrm{~V} \text { or } \\
347 \mathrm{~V} \text {. }\end{array}$ \\
\hline Chile & NA & \\
\hline People's Rep China & NA & \\
\hline Hong Kong, China & NA & \\
\hline Indonesia & NA & \\
\hline Japan & NA & \\
\hline
\end{tabular}




\begin{tabular}{|c|c|c|}
\hline Republic of Korea & \begin{tabular}{|l} 
KS C8102 \\
\end{tabular} & $\begin{array}{l}\text { Mandatory labeling. The English versions of the FERROMAGNETIC } \\
\text { LAMP BALLAST test procedures are not available, however it is } \\
\text { supposed to be equivalent to JIS C } 8108 \text {. The JIS8108 covers the design } \\
\text { and construction of ballasts for fluorescent lamps. It is a combined } \\
\text { safety and performance standard based largely on IEC60920 (safety) } \\
\text { and IEC60921 (performance) and appears to be equivalent to these } \\
\text { standards in most respects. It covers ballasts used with a starter, rapid } \\
\text { and instant ballasts. } \\
\text { Mandatory labeling. The English versions of the ELECTRONIC } \\
\text { LAMP BALLAST test procedures are not available, however it is } \\
\text { supposed to be equivalent to IEC60929. The standard sets performance } \\
\text { requirements for electronic ballasts and rapid start ballasts in terms of } \\
\text { the ratio of luminous output in lieu of the measurement of the lamp } \\
\text { wattage. }\end{array}$ \\
\hline Malaysia & MS 141 & $\begin{array}{l}\text { The test procedure for FERROMAGNETIC FLUORESCENT LAMP } \\
\text { BALLASTS is identical to IEC60921-1998, and only covers } \\
\text { ferromagnetic ballasts. Reference is made to IEC60929 for the } \\
\text { performance of electronic ballasts. The only difference is the addition } \\
\text { of a brief Appendix to determine the ballast loss test which is required } \\
\text { for local Malaysian regulations. This requires the measurement and } \\
\text { reporting of the lamp power, lamp voltage, current and total power } \\
\text { using both the test ballast and the reference ballast on the reference } \\
\text { lamp. The ballast loss is calculated from the total circuit power less the } \\
\text { lamp power. The reference ballast power is used to check that the lamp } \\
\text { is within specification, rather than to adjust to the results on the test } \\
\text { ballast. }\end{array}$ \\
\hline Mexico & NA & \\
\hline New Zealand & NA & \\
\hline Papua New Guinea & NA & \\
\hline Peru & NA & \\
\hline Philippines & PNS 12-2:1996 & $\begin{array}{l}\text { The test procedure for FLUORESCENT LAMP BALLASTS is } \\
\text { supposed to be equivalent to IEC } 60921 \text { and is therefore covered by the } \\
\text { following section on the IEC standard. }\end{array}$ \\
\hline Russian Federation & NA & \\
\hline Singapore & NA & \\
\hline
\end{tabular}




\begin{tabular}{|c|c|c|}
\hline Chinese Taipei & $\begin{array}{l}\text { CNS3888-85 } \\
\text { CNS927-96 }\end{array}$ & $\begin{array}{l}\text { CNS3888 for FLUORESCENT LAMP BALLASTS sets out a method } \\
\text { of test including start voltage test, secondary voltage test, cathode } \\
\text { pre0heat current, output current and power, lamp current waveform, } \\
\text { power factor, moisture withstand, temperature rise, insulation } \\
\text { resistance and insulation voltage. Most of these tests are similar in type } \\
\text { and method to IEC60920 and IEC60921. } \\
\\
\text { CNS927-96 for FLUORESCENT LAMP BALLASTS sets out } \\
\text { acceptance limits for tests conducted under CNS3888. These include } \\
\text { construction and performance requirements. The performance } \\
\text { requirements are almost identical to those set out in IEC60920 and } \\
\text { IEC60921 although there are some minor deviations for specialized } \\
\text { product types and all product classifications are not identical. }\end{array}$ \\
\hline Thailand & TIS23-2521 & $\begin{array}{l}\text { The test procedure for FLUORESCENT LAMP BALLASTS are based } \\
\text { on IES } 82 \text { for ballasts which was withdrawn many years ago. It is } \\
\text { assumed that the more recent standard IEC } 60921 \text { is broadly equivalent } \\
\text { to the TIS standard, but it's not available in English so conformation } \\
\text { has not yet been possible. }\end{array}$ \\
\hline USA & $\begin{array}{l}\text { 10CFR430 Sub } \\
\text { Part B, App Q }\end{array}$ & $\begin{array}{l}\text { All of the test conditions for FLUORESCENT LAMP BALLASTS are } \\
\text { externally referenced to ANSI C82.2. The test procedures are broadly } \\
\text { in line with the requirements for Canada. The standard applies to the } \\
\text { following fluorescent lamp ballasts types: } 40 \mathrm{~T} 12 \text { rapid start; } 96 \mathrm{~T} 12 \\
\text { rapid start or } 96 \mathrm{~T} 12 \mathrm{HO} \text { instant start for either } 120 \mathrm{~V} \text { or } 277 \mathrm{~V} \text { only . All } \\
\text { setup and conditions are specified in ANSI C82.2. }\end{array}$ \\
\hline Vietnam & NA & \\
\hline
\end{tabular}




\subsection{LIGHTING -- COMPACT FLOURESCENT LAMPS (CFLs)}

\section{Introduction}

In Task 2 it was suggested that CFLs could replace 50\% of incandescent light bulbs. For consumers to pay more for CFLs they will expect them to be reliable and meet certain performance requirements. Listed below are some tests and equipment needed to perform not only efficiency but also reliability and performance tests.

\section{Discussion}

- Can their incandescent integrating sphere and "photosensor" be used to compare CFL's with incandescent light bulbs even if they output light at different frequencies?

- Yes, according to the lighting experts at LBNL the photometer they use accounts for how the human eye perceives light and is sensitive to these frequencies, however, the paint inside the integrating sphere must not absorb the visible frequencies that we want to record.

- What is needed to compare the efficacy of different CFLs?

- In addition to the instrumentation listed below, an integrating sphere and a reference light bulb is used.

Test Procedure \& Performance Standards

Some of the test procedures used for compact flourescent lamps are listed below.

\section{Canada}

CAN/CSA-C861-95

COMPACT FLUORESCENT LAMPS is set out in various IES and ANSI standards (ANSI C78.1,78.3, 78.385, CIE 13.3, IES LM9, LM16, LM58)

\section{Hong Kong}

The test procedure for COMPACT FLUORESCENT LAMPS is set out in IEC60901, IEC90969 and CIEC 84.

\section{Korea}

IEC60901-single-capped flourescent lamps-performance and safety requirements.

\section{Mexico}

NOM 017

The test procedure for COMPACT FLUORESCENT LAMPS is equivalent to IEC60901 but the NOM contains energy efficiency requirements as well. 
USA

10CFR430 Sub Part B, Appendix R

Mandatory labeling. The test conditions for INCANDESCENT GLS AND REFLECTOR

LAMPS, COMPACT FLUORESCENT LAMPS and LINEAR FLOURESCENT LAMPS are externally referenced to IES standards. The test procedures are broadly in line with the requirements of Canada.

Table 6.6 Typical Instrumentation for Flourescent Lamps

\begin{tabular}{|l|l|l|l|}
\hline Instrument & Brand & Specification & Price \\
\hline $\begin{array}{l}\text { V-A-W Power Meter } \\
\text { with harmonic analyzer }\end{array}$ & & & $\$ 10,000$ \\
Voltage Regulator & & & \\
\hline Integrating Sphere & & & $\$ 75,000$ \\
\hline
\end{tabular}

Total Equipment Costs

Other costs included under Lighting - Ballasts

\section{Other Testing Requirements}

1. Temperature controlled room

2. Integrating Sphere with photometric detector for measuring light output.

Equipment \& Testing Requirements Listed in IEC969 Appendix A- Self-ballasted lamp

1. Draught-proof room (draft-free)

2. Ambient temperature $25 \pm 1{ }^{\circ} \mathrm{C}$

3. Relative humidity of $65 \%$ maximum

4. Test voltage $\pm 2 \%$ at the moment of measurements.

5. Total harmonic content of the supply voltage shall not exceed $3 \%$

6. Measure in a vertical base-up position

7. Age VPC lamps for $100 \mathrm{~h}$ before tests

\section{Performance Testing}

May want a room to measure the life of a CFL. A rack connects rows of lamps to a fixture and a photocell is attached to each lamp. A computer monitors the light and records the time when the photocell no longer is activated when the lamp has power to it. 
Table 6.7 APEC Test Procedure Standards for Lighting

\begin{tabular}{|c|c|c|}
\hline Country & Type of Standard & Comments \\
\hline Australia & NA & \\
\hline Brunei & NA & \\
\hline Canada & $\begin{array}{l}\text { CAN/CSA-C } 862-95 \\
\text { CAN/CSA-C } 819-95 \\
\text { CAN/CSA-C } 861-95\end{array}$ & $\begin{array}{l}\text { Mandatory labeling. Test procedures for INCANDESCENT REFLECTOR } \\
\text { LAMPS are similar to US DOE. The light output and the power of the lamp } \\
\text { is determined to determine its efficiency. The standard sets out a range of } \\
\text { mandatory requirements for a lamp in addition to efficacy. The test } \\
\text { procedures are broadly in line with the requirements for the USA. The } \\
\text { standard is applicable to lamps rated from } 40 \mathrm{~W} \text { to } 205 \mathrm{~W} \text { with an E26 or } \\
\text { E26 skirted medium screw base and a diameter of greater than } 70 \mathrm{~mm} \text { (PAR } \\
\text { and R types). It is not applicable to colored lamps, heat lamps, lamps for } \\
\text { special applications, ER or BR shaped lamps or bowl mirror lamps. } \\
\text { Mandatory labeling. The test procedure for FLUORESCENT LAMPS is set } \\
\text { out in various IES and ANSI standards (ANSI C78.1,78.3, 78.385, CIE } \\
\text { 13.3, IES LM9, LM16, LM58) and is being considered for adoption in the } \\
\text { near future. The procedure is essentially equivalent to that required for the } \\
\text { USA. The standard is applicable to a limited range of fluorescent lamps as } \\
\text { follows: } 1200 \text { mm linear rapid start lamps; } 600 \text { mm U shaped rapid start } \\
\text { lamps; and 2400mm linear rapid and instant start lamps. The standard } \\
\text { excludes several specialist lighting products. } \\
\text { The test procedure for COMPACT FLUORESCENT LAMPS is set out in } \\
\text { various IES and ANSI standards (ANSI C78.1,78.3, 78.385, CIE 13.3, IES } \\
\text { LM9, LM16, LM58) The standard specifies a range of performance related } \\
\text { requirements such as power input (declared versus actual), starting time, } \\
\text { run-up time, crest factor and system efficacy (Lumens per watt). The system } \\
\text { of measuring total power input and light output is used, although a } \\
\text { minimum light output requirement is not specified. }\end{array}$ \\
\hline Chile & $\mathrm{NA}$ & \\
\hline $\begin{array}{l}\text { People's Rep } \\
\text { of China }\end{array}$ & NA & \\
\hline $\begin{array}{l}\text { Hong Kong, } \\
\text { China }\end{array}$ & & $\begin{array}{l}\text { The test procedure for COMPACT FLUORESCENT LAMPS is set out in } \\
\text { IEC60901, IEC } 90969 \text { and CIEC } 84 \text {. }\end{array}$ \\
\hline Indonesia & NA & \\
\hline Japan & JIS C7601 & $\begin{array}{l}\text { The test procedure for LINEAR FLOURESCENT LAMPS covers all } \\
\text { aspects of flourescent lamps including performance, design, construction, } \\
\text { life, color and safety. The standard is based on a number of IEC standards } \\
\text { and the requirements appear to be largely compatible with these } \\
\text { requirements: IEC60081-double-capped flourescent lamps-performance and } \\
\text { safety specifications; IEC60901-single-capped flourescent } \\
\text { lamps-performance and safety requirements. }\end{array}$ \\
\hline
\end{tabular}




\begin{tabular}{|c|c|c|}
\hline $\begin{array}{l}\text { Republic of } \\
\text { Korea }\end{array}$ & $\begin{array}{l}\text { KS C7601 } \\
\text { KS C7621 }\end{array}$ & $\begin{array}{l}\text { Mandatory labeling. The English version of this test procedure for } \\
\text { INCANDESCENT LAMPS is not available, however, the JIS C7501 was } \\
\text { analyzed, which is supposed to be equivalent. The standard covers the } \\
\text { design and construction of A and PS type general lighting service (GLS) } \\
\text { lamps. The standard also specifies initial performance characteristics, life, } \\
\text { marking and related requirements. The general requirements appear to be } \\
\text { broadly in accordance with IEC } 60064 \text {. } \\
\text { Mandatory labeling. The English version of this test procedure for LINEAR } \\
\text { FLOURESCENT LAMPS is not available, however, the JIS C7601 was } \\
\text { analyzed, which is supposed to be equivalent. The standard covers all } \\
\text { aspects of flourescent lamps including performance, design, construction, } \\
\text { life, color and safety. The standard is based on a number of IEC standards } \\
\text { and the requirements appear to be largely compatible with these } \\
\text { requirements: IEC60081-double-capped flourescent lamps-performance and } \\
\text { safety specifications; IEC60901-single-capped flourescent } \\
\text { lamps-performance and safety requirements. } \\
\text { The English version of this test procedure is not available, however, it is } \\
\text { based on KS C8100 and KS C7601, as well as parts of IEC60969. The KS } \\
\text { standards are equivalent to JIS C8108 and JIS C7601. }\end{array}$ \\
\hline Malaysia & & $\begin{array}{l}\text { The program is under construction and the test procedures to be used have } \\
\text { not yet been determined. }\end{array}$ \\
\hline Mexico & NOM 017 & $\begin{array}{l}\text { The test procedure for COMPACT FLUORESCENT LAMPS is equivalent } \\
\text { to IEC60901 but the NOM contains energy efficiency requirements as well. }\end{array}$ \\
\hline New Zealand & & $\begin{array}{l}\text { There is no currently published test procedure for LINEAR } \\
\text { FLOURESCENT LAMPS, however, a joint Australian/New Zealand } \\
\text { standard for the measurement of efficacy of both ballasts and lamps (based } \\
\text { on EN50294) si currently under development. }\end{array}$ \\
\hline Peru & $\mathrm{NA}$ & \\
\hline \multirow[t]{2}{*}{ Philippines } & & $\begin{array}{l}\text { The test procedure for LINEAR FLOURESCENT LAMPS is PNS } \\
02: 1994 \text {. This standard is supposed to be equivalent to IEC60081. }\end{array}$ \\
\hline & PNS 603-2:1993 & $\begin{array}{l}\text { The test procedure for COMPACT FLUORESCENT LAMPS IS based on } \\
\text { IEC60969. This program is under consideration and it has not been possible } \\
\text { to obtain a copy of the test procedure for analysis. }\end{array}$ \\
\hline $\begin{array}{l}\text { Russian } \\
\text { Federation }\end{array}$ & $\mathrm{NA}$ & \\
\hline Singapore & NA & \\
\hline Chinese Taipei & & $\begin{array}{l}\text { Program is under construction, but the test procedures to be used have not } \\
\text { yet been determined. }\end{array}$ \\
\hline Thailand & NA & \\
\hline USA & $\begin{array}{l}\text { 10CFR430 Sub Part } \\
\text { B, Appendix R }\end{array}$ & \\
\hline Vietnam & NA & \\
\hline
\end{tabular}




\subsection{HOUSEHOLD REFRIGERATORS}

\section{Introduction}

Refrigerators of five different brands are imported into Sri Lanka. There are no local domestic refrigerators being built in Sri Lanka. Most refrigerator imports come from: Thailand (58\%), Singapore (24\%) and China (10\%). The most common size refrigerator is $8 \mathrm{cu}$. ft. in volume.

\section{Test Procedures}

There are two main refrigerator methodologies, ISO and U.S. DOE. Although they are different, most of the equipment and test facilities could be used to test to either test procedure. The various refrigerator test procedures are listed below.

Table 6.8 Test Procedures for Household Refrigerators

\begin{tabular}{|c|c|c|}
\hline Standard & Equivalent to or based on & Country \\
\hline AS/NZS 4474.1-97 & $\begin{array}{l}\text { Influenced by ISO } 5155,7371,8187,8561 \text {; U.S. DOE, must } \\
\text { satisfy the AHAM pull down test }\end{array}$ & $\begin{array}{l}\text { Australia, } \\
\text { New Zealand }\end{array}$ \\
\hline CAN/CSA-C300-M91 & $\begin{array}{l}\text { US DOE, ANSI/AHAM HRF-1-1998 } \\
\text { uses door openings for variable defrost systems }\end{array}$ & Canada \\
\hline GB/T8059.1, GB/T8059.2, & $\begin{array}{l}\text { ISO } 5155, \text { ISO } 7371, \\
\text { ISO } 8187, \text { ISO } 8561\end{array}$ & $\begin{array}{l}\text { China, } \\
\text { Hong Kong }\end{array}$ \\
\hline modified ISO 7371-95(E) & tested at 30C ambient, $60-75 \% \mathrm{RH}$ & Indonesia \\
\hline JIS C 9607-93 & $\begin{array}{l}\text { ISO } 5155 \text {, ISO } 7371, \\
\text { ISO } 8187, \text { ISO } 8561 \\
\text { exceptions: tested at two ambient temperatures }\end{array}$ & Japan \\
\hline KS C 9305-96 & $\begin{array}{l}\text { influenced by JIS C } 960 T 7 \& \text { ISO } \\
\text { ambient }=30 \mathrm{C},\end{array}$ & Korea \\
\hline NOM-015-ENER-97 & US DOE 1993 CFR part 430 Subpart B & Mexico \\
\hline Peru & Similar to ISO 5155, ISO 7371, ISO 8187, ISO 8561 & Peru \\
\hline PNS $1474,1475,1476,1477$ & references ISO & Philippines \\
\hline GOST 16317-87 & ISO & Russia \\
\hline ISO 8187, ISO 8561 & & Singapore \\
\hline CNS 2062-95, CNS 9577-89 & JIS \& ISO; ambient temp. $=30 \mathrm{C}$ & Chinese Taipei \\
\hline TIS 455-2537 & $\begin{array}{l}\text { Ref. ISO } 7371-1995 \text { not equivalent but not in a way that } \\
\text { would affect the rated energy consumption }\end{array}$ & Thailand \\
\hline U.S. DOE 10CFR430 & ref. ANSI/AHAM HRF-1-1998 & U.S.A. \\
\hline SLS 723:1985 & $\begin{array}{l}\text { seems to be adapted from ISO standards } \\
\text { ambient humidity: } 75-90 \% \mathrm{RH}\end{array}$ & Sri Lanka \\
\hline
\end{tabular}




\section{ISO Test Procedures}

For Sri Lanka the ISO test at tropical test conditions seems most appropriate. The U.S. DOE test would also suite climate requirements for Sri Lanka. The standards pertaining to the different sub-categories for household refrigerators, freezers and refrigerator/freezers are shown below:

- $\quad$ ISO 5155 - Food Freezers

- $\quad$ ISO 7371 - Household Refrigerators

- $\quad$ ISO 8187 - Refrigerator-freezers

- $\quad$ ISO 8561 - Refrigerators cooled by internal forced air circulation

\section{General Requirements of ISO 7371 - Household Refrigerators}

Energy consumption of a refrigerating appliance over a period of $24 \mathrm{~h}$, running under stable operating conditions at an ambient temperature of $+25 \mathrm{C}$ (in the case of class SN-extended temperate, class $\mathrm{N}$-temperate, and class ST-subtropical appliances) or $+32 \mathrm{C}$ (in the case of class T-tropical appliances) and measured under the specified test conditions.

The test period shall start at the beginning of a operating cycle - at least $24 \mathrm{~h}$ after stable operating conditions have been attained - and shall be of at least $24 \mathrm{~h}$ duration and shall comprise a whole number of operating cycles. If one operating cycle is not complete during a $24 \mathrm{~h}$ period, the test period shall be terminated at the end of 48 hours.

Table 6.9 ISO 7371 - Household Refrigerators

\begin{tabular}{|c|c|c|c|}
\hline Instruments & Accuracy & Tolerance & Comments \\
\hline \multirow[t]{2}{*}{$\begin{array}{l}\text { Temperature } \\
\text { Measuring } \\
\text { Device }\end{array}$} & $+/-0.3 \mathrm{~K}$ & $\begin{array}{l}\text { The interior temperatures have to } \\
\text { be maintained at an average of } \\
5+/-0.5 \mathrm{C} \text { for the refrigerator } \\
\text { compartment, }-6+/-0.5 \mathrm{C} \text { for a } \\
1 \text {-star frozen food compartment, } \\
-12+/-0.5 \text { for a } 2 \text {-star frozen food } \\
\text { compartment and }-18+/-0.5 \mathrm{C} \text { for a } \\
3 \text { or } 4-\text { star frozen food } \\
\text { compartment. }\end{array}$ & $\begin{array}{l}\text { The temperature sensors are } \\
\text { thermocouples placed inside, and in } \\
\text { good thermal contact with, a copper } \\
\text { or brass cylinder having a mass of } \\
25 \mathrm{~g} \text { and diameter and height of } \\
\text { about } 15.2 \mathrm{~mm} \text {. } \\
\text { Climate Classes Ambient Temps: } \\
\text { SN/10-32C; N/16-32C; } \\
\text { ST/16-38C; T/16-43C }\end{array}$ \\
\hline & & $\begin{array}{l}\text { The compartment interior } \\
\text { temperature is defined as the mean } \\
\text { value of three sensor temperatures } \\
\text { in the fresh food compartments. }\end{array}$ & $\begin{array}{l}\text { The measured storage volume shall } \\
\text { not be less than the rated storage } \\
\text { volume by more than } 3 \% \text { of the } \\
\text { latter or } 1 \text { liter, whichever is the } \\
\text { greater value. }\end{array}$ \\
\hline $\begin{array}{l}\text { Watt-hour } \\
\text { meter }\end{array}$ & $+/-1.0 \%$ & $\begin{array}{l}\text { Watt meters shall be readable to } \\
0.01 \mathrm{kWh} \text { and accuracy shall be } \\
\text { stated in the test report. }\end{array}$ & \\
\hline
\end{tabular}


Table 6.10 Refrigerator and Freezer Test Facility Instrument List ${ }^{4}$

List of Test Procedure Instruments and Costs as determined by IIEC for a test project in Indonesia.

(prices have been increased by 20\% from the original 1996 prices)

\begin{tabular}{|c|c|c|c|c|c|c|}
\hline Instruments & Specifications & Quant & & Brand & Cost/Unit & Total Cost \\
\hline \multicolumn{7}{|c|}{ Data Acquisition and Control Component } \\
\hline Data acquisition components & Hardware configuration & 1 & set & $\begin{array}{l}\text { Fluke Helios I Model } \\
\text { 2289A }\end{array}$ & $\$ 18,000$ & $\$ 18,000$ \\
\hline & A/D converter model 161 & & & & & \\
\hline & $\begin{array}{l}\text { Thermocouple input model } 175 \\
\text { ( } 5 \text { boards) }\end{array}$ & & & & & \\
\hline & $\begin{array}{l}\text { Input connector model } 162 \text { (5 } \\
\text { boards) }\end{array}$ & & & & & \\
\hline & $\begin{array}{l}\text { 4-20 mA analog output model } \\
170\end{array}$ & & & & & \\
\hline & Extender Chassis & & & & & \\
\hline Digital power meter & $\begin{array}{l}\text { Minimum accuracy } 0.1 \% \\
\text { reading }\end{array}$ & 6 & units & $\begin{array}{l}\text { Yokogawa Model } \\
\text { 2533E }\end{array}$ & $\$ 720$ & $\$ 43,200$ \\
\hline & GPIB communications interface & & & & & \\
\hline & Frequency measurement option & & & & & \\
\hline & Power integrator option & & & & & \\
\hline & Simultaneous VAW display & & & & & \\
\hline SCR power controller & $\begin{array}{l}\text { 4-20 mA control input } \\
\text { Zero crossing gating signal } \\
26 \text { Amp Min rating }\end{array}$ & 1 & unit & Phasetronics & 300 & 300 \\
\hline
\end{tabular}




\begin{tabular}{|c|c|c|c|c|c|c|}
\hline Instruments & \multirow{2}{*}{$\begin{array}{l}\text { Specifications } \\
\text { Type T with special limit of } \\
\text { error; Gauge 24AWG; Ext } \\
\text { Wire, gauge AWG }\end{array}$} & \multicolumn{2}{|c|}{ Quantity } & \multirow{2}{*}{$\frac{\text { Brand }}{\text { Omega or TC }}$} & \multirow{2}{*}{$\begin{array}{l}\text { Cost/Unit } \\
\$ \$ 1,440\end{array}$} & \multirow{2}{*}{$\frac{\text { Total Cost }}{\$ \$ 1,440}$} \\
\hline $\begin{array}{l}\text { Thermocouple wire set and } \\
\text { connectors }\end{array}$ & & 1 & lot & & & \\
\hline Proportional control value & $\begin{array}{l}\text { 3-15 PSIG Pneumatic control } \\
\text { input; } 1 / 2 \text { " pipe diameter }\end{array}$ & 1 & unit & Jordan & $\$ 720$ & $\$ 720$ \\
\hline $\begin{array}{l}\text { Current to pressure } \\
\text { transducer }\end{array}$ & $\begin{array}{l}\text { 4-20 mA input; 3-15 PSIG } \\
\text { output }\end{array}$ & & & & & \\
\hline Supervisory computer & $\begin{array}{l}\text { Minimum specifications: } \\
486 \text { series CPU } \\
500 \text { MB fixed disk } \\
8 \text { MB DRAM }\end{array}$ & 1 & unit & & $\$ 3,600$ & $\$ 3,600$ \\
\hline Timer/Counter & $\begin{array}{l}\text { Relay contact output; remote } \\
\text { switch input; remote start/stop; } \\
24 \text { hour timing cycle } \\
\text { Animated display } \\
\text { Comprehensive math } \\
\text { calculation }\end{array}$ & 6 & units & Eagle Control & $\$ 360$ & $\$ 2,160$ \\
\hline \multicolumn{7}{|l|}{ Air Reconditioning Equipment } \\
\hline Water chiller unit & 3 ton refrigerating capacity & 1 & unit & & $\$ 12,000$ & $\$ 12,000$ \\
\hline Circulating blower & 80 cu m capacity & 1 & unit & & $\$ 1,200$ & $\$ 1,200$ \\
\hline Motor driver & 1.5 HP capacity & 1 & unit & & $\$ 420$ & $\$ 420$ \\
\hline Cooling coils & 3 ton cooling capacity & 1 & unit & & $\$ 1,440$ & $\$ 1,440$ \\
\hline Vaporizer Box & $\begin{array}{l}3-2 \mathrm{~kW} \text { heater capacity } \\
8 \text { liter water reservoir }\end{array}$ & 1 & $\begin{array}{l}\text { assem } \\
\text { bly }\end{array}$ & & $\$ 2,400$ & $\$ 2,400$ \\
\hline Duct assembly & & 1 & unit & & $\$ 3,600$ & $\$ 3,600$ \\
\hline
\end{tabular}




\begin{tabular}{|c|c|c|c|c|c|c|}
\hline Instruments & Specifications & \multicolumn{2}{|c|}{ Quantity } & Brand & Cost/Unit & Total Cost \\
\hline \multicolumn{7}{|l|}{ Psychometric Box } \\
\hline RTD temperature sensor & Pt $100 \mathrm{Ohm}$ & 2 & units & $L \& N$ & $\$ 240$ & $\$ 480$ \\
\hline Blower and motor assembly & $\begin{array}{l}8 \text { cu m capacity } \\
1 / 5 \text { HP motor }\end{array}$ & 1 & $\begin{array}{l}\text { assem } \\
\text { bly }\end{array}$ & & $\$ 180$ & $\$ 180$ \\
\hline \multicolumn{7}{|l|}{ Test Chamber } \\
\hline & $\begin{array}{l}50 \mathrm{~mm} \text { thick bonded } \\
\text { polystyrene; } 8.5 \mathrm{~m} 1 \text { X } 3 \mathrm{~m} \mathrm{H} \mathrm{X} \\
4 \mathrm{~m} \mathrm{~W} \text {; capacity } 6 \text { units }\end{array}$ & 1 & $\begin{array}{l}\text { assem } \\
\text { bly }\end{array}$ & Bondor & & \\
\hline \multicolumn{7}{|l|}{ Automatic Voltage Supply Regulator } \\
\hline & $20 \mathrm{kVA}$; regulation: $+/-2$ volts & 1 & unit & $\begin{array}{l}\text { Hypertronics or } \\
\text { Yamabishi }\end{array}$ & $\$ 14,400$ & $\$ 14,400$ \\
\hline \multicolumn{6}{|l|}{ Total Equipment Cost } & $\$ 114,000$ \\
\hline \multicolumn{6}{|c|}{ Electrical, Wiring \& Plumbing Cost @ $8.0 \%$ of Equipment Cost } & $\$ 9,120$ \\
\hline \multicolumn{6}{|l|}{ Total Cost } & U.S. $\$ 123,120$ \\
\hline
\end{tabular}


Total Equipment \& Air Reconditioning Costs $\ldots \ldots \ldots \ldots \ldots \ldots \ldots \ldots \ldots \ldots$ \$114,000 (does not include land, building or engineering costs)

Electric Wiring $\ldots \ldots \ldots \ldots \ldots \ldots \ldots \ldots \ldots \ldots \ldots \ldots \ldots \ldots \ldots \ldots \ldots \ldots \ldots \ldots \ldots \ldots \ldots \ldots, \mathbf{\$ 9}, \mathbf{1 2 0}$

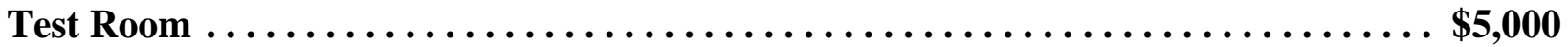

Test Chamber $\ldots \ldots \ldots \ldots \ldots \ldots \ldots \ldots \ldots \ldots \ldots \ldots \ldots \ldots \ldots \ldots \ldots \ldots \ldots \ldots \ldots \ldots \ldots \ldots, 0 \ldots 00$

Support Equipment $\ldots \ldots \ldots \ldots \ldots \ldots \ldots \ldots \ldots \ldots \ldots \ldots \ldots \ldots \ldots \ldots \ldots \ldots \ldots \ldots \ldots \ldots \ldots, 0 \ldots$

Training Costs $\ldots \ldots \ldots \ldots \ldots \ldots \ldots \ldots \ldots \ldots \ldots \ldots \ldots \ldots \ldots \ldots \ldots \ldots \ldots \ldots \ldots \ldots \ldots \ldots, 0 \ldots 00$

- $\quad$ Visit to other test laboratory

- Consultant time

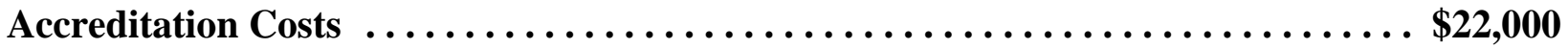

- Test of refrigerator at another test laboratory for comparison

Standard Purchase $\ldots \ldots \ldots \ldots \ldots \ldots \ldots \ldots \ldots \ldots \ldots \ldots \ldots \ldots \ldots \ldots \ldots \ldots \ldots \ldots$

- $\quad$ Purchase of test procedure standards

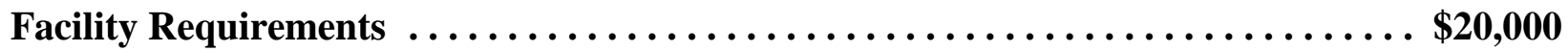

- $\quad$ Climate controlled room approximately $36 \mathrm{~m}^{2}$ and $3 \mathrm{~m}$ high

- $\quad$ No draft in room

- $\quad$ Storage space before and after testing will need to be made available

Staffing Requirements $\ldots \ldots \ldots \ldots \ldots \ldots \ldots \ldots \ldots \ldots \ldots \ldots \ldots \ldots \ldots \ldots \ldots \ldots . \$ \ldots 5,829$

- (2) test technicians

- (1) engineer/supervisor

- testing, data reduction, documentation, measurement of refrigerator volume

Operation Costs $\ldots \ldots \ldots \ldots \ldots \ldots \ldots \ldots \ldots \ldots \ldots \ldots \ldots \ldots \ldots \ldots \ldots \ldots \ldots \ldots \ldots$

- $\quad$ Electricity cost to condition test room

Calibration services $\ldots \ldots \ldots \ldots \ldots \ldots \ldots \ldots \ldots \ldots \ldots \ldots \ldots \ldots \ldots \ldots \ldots \ldots \ldots . \$ \ldots 5,700$

- $\quad$ Calibration \& maintenance of instruments

TOTAL COSTS

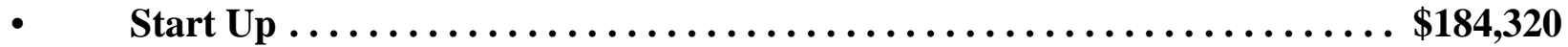

- $\quad$ Recurring $\ldots \ldots \ldots \ldots \ldots \ldots \ldots \ldots \ldots \ldots \ldots \ldots \ldots \ldots \ldots \ldots \ldots \ldots \ldots \ldots \ldots \ldots \ldots \ldots, 111$ 


\section{Testing Capabilities}

Five days per refrigerator test (including one day to measure the volume)

Six refrigerators tested at one time.

\section{$\underline{\text { Alternate ITS Assessment }}$}

\section{Forward}

Testing of a refrigerator requires a specially designed test room to simulate natural convection air currents. On certain refrigerator designs, results of tests can be widely different when the velocity of the air adjacent to the unit under test is higher than the test standard allows.

\section{Proposed Capabilities}

\section{Equipment}

A test room constructed to accommodate four samples would be necessary to properly evaluate the number of models produced. A facility of 65 square meters would be needed accommodate a test room, storage of test samples, and office space.

\section{Staffing Requirements}

Minimum staffing requirements for one test facility capable of performing from $100-200$ tests per year per test stand are as follows:

- Department Manager

- Department Secretary

- $\quad$ (2) Test Engineering Technicians

Note:

Department Manager and Department Secretary may be shared when multiple facilities are specified. Possibly across different product test areas as well. To a lesser extent, technicians can be shared within the same product test area. Particularly when more then one similar highly automated test facility exists.

\section{Cost}

Total cost for one complete automated four-station refrigerator test facility is estimated at US $\$ 350,000$.

\section{Additional References:}

Symposium on Domestic Refrigeration Appliances, APEC Project EWG 4/99T, March 2000; prepared by Lloyd Harrington of Energy Efficient Strategies, Melbourne, Australia 


\subsection{ROOM AIR CONDITIONERS}

\section{Introduction}

Currently Sri Lanka has a low saturation of residential air conditioners. There is no local manufacturing of air conditioners in Sri Lanka. Imports come mainly from: South Korea (45\%), Thailand (18\%), Singapore (13\%), India (8\%) and China (6\%).

In a meeting with National an importer and retailer of appliances in Sri Lanka, I learned that 60\% of their sales are for window units and $40 \%$ are for split and package units. Split units seem to be of the mini-split variety. The most popular capacities are 1 and 1.5 ton units, with $40 \%$ of the units sold being 1 ton and about $22 \%$ are 1.5 ton units. Businesses usually have 2 ton units; $17 \%$ 1.5 ton and $70 \% 2$ ton units. For commercial use, $80 \%$ are of the split type. Air conditioners are a very price sensitive market. Air conditioners are imported from Japan (National, Seidel Hatachi, Toshiba), Korea (ABANS-LG, Singer, Samsung).

\section{Test Procedure Standards}

The table below shows test procedures currently in use by various countries.

Table 6.11 Room Air Conditioning Test Procedures

\begin{tabular}{|c|c|c|}
\hline Standard & Equivalent to or based on & Country \\
\hline AS/NZS 3823.1.1-1998 & $\begin{array}{l}\text { ISO } 5151 \text { Only calorimeter method of test is } \\
\text { acceptable for energy labeling }\end{array}$ & Australia \\
\hline CAN/CSA-C368.1-M90 & U.S. DOE / ASHRAE-16-69 \& ASHRAE90-1-1989 & Canada \\
\hline GB/T7725-1996 & based on ISO5151, T1 test condition & China \\
\hline $\begin{array}{l}\text { JIS C 9612-94 } \\
\text { JIS B 8616-93 }\end{array}$ & different system to classify then ISO & Japan \\
\hline $\begin{array}{l}\text { KS C 9306-97 } \\
\text { KS B 6369-95 }\end{array}$ & different system to classify then ISO & Korea \\
\hline $\begin{array}{l}\text { NOM-073-SCFI-94 } \\
\text { NOM-011-ENER-96 }\end{array}$ & ASHRAE-16-69 (U.S.) & Mexico \\
\hline PNS 240-89 & ISO & Philippines \\
\hline GOST 26963-86 & ISO & Russia \\
\hline CNS 3615 & different system to classify then ISO & Chinese Taipei \\
\hline TIS 1155-2536(1993) & $\begin{array}{l}\text { amalgamation of ISO/R859-68, ARI210/240-84 and } \\
\text { JISB8615-84 and JISB8616-84 }\end{array}$ & Thailand \\
\hline $\begin{array}{l}\text { U.S. DOE CFR } 430 \text { SubpartB, } \\
\text { App. F, DOE CFR } 430 \text { App. M }\end{array}$ & $\begin{array}{l}\text { conditions: ANS Z234.1-72 } \\
\text { method: ASHRAE-16-69 }\end{array}$ & U.S.A. \\
\hline $\begin{array}{l}\text { SLS 524:1981 self-contained room } \\
\text { air conditioners }\end{array}$ & assistance from ISO and Indian Standards Institution & Sri Lanka \\
\hline
\end{tabular}


Table 6.12 Test Procedures for Room Air Conditioners-- ISO 5151

\begin{tabular}{|c|c|c|c|c|}
\hline Instruments & Uncertainty & Accuracy & Tolerance & Comments \\
\hline $\begin{array}{l}\text { Water } \\
\text { Temperature } \\
\text { Air Dry-Bulb } \\
\text { Temp } \\
\text { Air Wet-Bulb } \\
\text { Temp }\end{array}$ & $\begin{array}{l}+/-0.1 \mathrm{C} \\
+/-0.2 \mathrm{C} \\
+/-0.2 \mathrm{C}\end{array}$ & & $\begin{array}{l}\text { The smallest scale division of the } \\
\text { temperature-measuring instrument } \\
\text { should not exceed twice the specified } \\
\text { accuracy. } \\
\text { For example, for the specified accuracy } \\
\text { of }+/-0.05 \mathrm{C} \text {, the smallest scale division } \\
\text { should not exceed +/-0.1C. } \\
\text { For measurements of Wet-Bulb } \\
\text { temperature, sufficient wetting should } \\
\text { be provided and sufficient time should } \\
\text { be allowed for the state of evaporative } \\
\text { equilibrium to be attained. } \\
\text { For mercury-in-glass thermometers } \\
\text { having a bulb diameter not over } \\
6.5 m m, \text { temperatures should be read } \\
\text { under conditions which ensure a } \\
\text { minimum air velocity of } 5 \mathrm{~m} / \mathrm{s} \text {. }\end{array}$ & $\begin{array}{l}\text { The maximum permissible } \\
\text { variation of any } \\
\text { observation represents the } \\
\text { greatest permissible } \\
\text { difference between } \\
\text { maximum and minimum } \\
\text { instrument observations } \\
\text { during the test. When } \\
\text { expressed as a percentage, } \\
\text { the maximum allowable } \\
\text { variation is the specified } \\
\text { percentage of the } \\
\text { arithmetical mean of the } \\
\text { observations. }\end{array}$ \\
\hline $\begin{array}{l}\text { Water Volume } \\
\text { Flow } \\
\text { Air Volume Flow }\end{array}$ & $\begin{array}{l}+/-0.5 \% \\
+/-0.5 \%\end{array}$ & $+/-1.0 \%$ & $\begin{array}{l}\text { For air-flow rate measurements, the } \\
\text { minimum pressure differential should } \\
\text { be } 25 \mathrm{~Pa} \text { with an inclined-tube } \\
\text { manometer or micro-manometer; } 500 \\
\text { Pa with a vertical tube manometer. }\end{array}$ & \\
\hline $\begin{array}{l}\text { Barometric } \\
\text { Pressure } \\
\text { Micro-manometer } \\
(1.25-25 \mathrm{~Pa})\end{array}$ & & $\begin{array}{l}+/-0.1 \% \\
+/-0.25 \mathrm{~Pa}\end{array}$ & & \\
\hline $\begin{array}{l}\text { Manometer } \\
(25-500 \mathrm{~Pa}) \\
\text { Manometer } \\
(500 \mathrm{~Pa}+)\end{array}$ & & $\begin{array}{l}+/-2.5 \mathrm{~Pa} \\
+/-25 \mathrm{~Pa}\end{array}$ & & \\
\hline $\begin{array}{l}\text { Water Static } \\
\text { Pressure Diff } \\
\text { Air Static Pressure } \\
\text { Diff }\end{array}$ & $\begin{array}{l}+/-5 \mathrm{~Pa} \\
+/-5 \mathrm{~Pa} \text { for } \\
\mathrm{P}<100 \mathrm{~Pa} \\
+/-5 \% \mathrm{for} \\
\mathrm{P}>100 \mathrm{~Pa}\end{array}$ & & & \\
\hline $\begin{array}{l}\text { Electrical Inputs } \\
\text { Time } \\
\text { Mass } \\
\text { Speed }\end{array}$ & $\begin{array}{l}+/-0.5 \% \\
+/-0.2 \% \\
+/-1.0 \% \\
+/-1.0 \%\end{array}$ & & & \\
\hline
\end{tabular}


Table 6.13 Calibrated Calorimeter Room Instrument List

(Originally compiled by Terry Oliver of IIEC for Indonesia project)

Cost data reflects a 20\% estimated increase in prices from 1996.

\begin{tabular}{|c|c|c|c|c|c|}
\hline Instruments & Specifications & Quantity & Brand & Cost/Unit & Total Cost \\
\hline \multicolumn{6}{|c|}{ Data Acquisition and Control Component } \\
\hline Data acquisition instrument & Hardware configuration: & set & $\begin{array}{l}\text { Fluke Helios I Model } \\
\text { 2289A }\end{array}$ & $\$ 21,600$ & $\$ 21,600$ \\
\hline & A/D converter model 161 & & & & \\
\hline & RTD sensor input model 174 & & & & \\
\hline & Thermocouple input model 175 & & & & \\
\hline & AC voltage input model 160 & & & & \\
\hline & $\begin{array}{l}\text { 4-20 mA analog output model } \\
170\end{array}$ & & & & \\
\hline & Frequency input model 170 & & & & \\
\hline & $\begin{array}{l}\text { DC current (4-20 mA) input } \\
\text { model } 171\end{array}$ & & & & \\
\hline & Extender chassis & & & & \\
\hline $\begin{array}{l}30 \text { Point hybrid temperature } \\
\text { recorder }\end{array}$ & Type $\mathrm{T}$ thermocouple input & unit & $\begin{array}{l}\text { Yokogawa Model } \\
\text { HR2300 }\end{array}$ & $\$ 4,800$ & $\$ 4,800$ \\
\hline & Programmable chart speed & & & & \\
\hline & Math function & & & & \\
\hline & Programmable range & & & & \\
\hline
\end{tabular}




\begin{tabular}{|c|c|c|c|c|c|c|}
\hline Instruments & \multirow{2}{*}{$\begin{array}{l}\text { Specifications } \\
\begin{array}{l}\text { Minimum accuracy } 0.1 \% \\
\text { reading }\end{array}\end{array}$} & \multicolumn{2}{|c|}{ Quantity } & \multirow{2}{*}{$\begin{array}{l}\text { Brand } \\
\begin{array}{l}\text { Yokogawa Model } \\
2533 \mathrm{E}\end{array}\end{array}$} & \multirow{2}{*}{$\frac{\text { Cost/Unit }}{\$ 7,800}$} & \multirow{2}{*}{$\frac{\text { Total Cos }}{\$ 23,400}$} \\
\hline Digital power meter & & 3 & units & & & \\
\hline & GPIB communications interface & & & & & \\
\hline & Frequency measurement option & & & & & \\
\hline & Power integrator option & & & & & \\
\hline & Simultaneous VAW display & & & & & \\
\hline & $\mathrm{CT}$ ratio function & & & & & \\
\hline $\begin{array}{l}\text { Differential digital pressure } \\
\text { sensor/indicator set }\end{array}$ & Range: $0-50 \mathrm{~mm} \mathrm{WC}$ & 2 & units & Setra & $\$ 1,800$ & $\$ 3,600$ \\
\hline $\begin{array}{l}\text { Digital pressure } \\
\text { sensor/indicator set }\end{array}$ & Range: 0-100 mm WC & 2 & units & Setra & $\$ 1,800$ & $\$ 3,600$ \\
\hline Weighing balance & $\begin{array}{l}\text { Capacity: } 30 \mathrm{~kg} \text { with } 4-20 \mathrm{~mA} \\
\text { output }\end{array}$ & 2 & units & Ohaus & $\$ 3,600$ & $\$ 7,200$ \\
\hline SCR power controller & $\begin{array}{l}\text { 4-20mA control input } \\
\text { zero crossing gating signal } \\
\text { 25Amp min rating }\end{array}$ & 2 & units & Phasetronics & $\$ 300$ & $\$ 600$ \\
\hline $\begin{array}{l}\text { Turbine flow meter } \\
\text { totalizer/indicator set }\end{array}$ & Range: $0.5-100 \mathrm{lpm}$ & 1 & unit & Hoffer & $\$ 2,520$ & $\$ 2,520$ \\
\hline Inclined tube manometer & $\begin{array}{l}\text { range: } 0-50 \mathrm{~mm} \mathrm{WC} \\
0.01 \text { resolution }\end{array}$ & 1 & unit & Meriam & $\$ 480$ & $\$ 480$ \\
\hline $\begin{array}{l}\text { Thermocouple wire set } \\
\text { including extension and } \\
\text { connectors }\end{array}$ & $\begin{array}{l}\text { Type } \mathrm{T} \text { with special limit of } \\
\text { error }\end{array}$ & 1 & lot & Omega or TC & $\$ 1,200$ & $\$ 1,200$ \\
\hline
\end{tabular}




\begin{tabular}{|c|c|c|c|c|c|c|}
\hline Instruments & \multirow{2}{*}{$\begin{array}{l}\text { Specifications } \\
\text { Minimum specifications: } \\
486 \text { series CPU } \\
500 \text { MB fixed disk } \\
8 \text { MB DRAM } \\
\text { Math co-processor }\end{array}$} & \multicolumn{2}{|c|}{ Quantity } & \multirow[t]{2}{*}{ Brand } & \multirow{2}{*}{$\frac{\text { Cost/Unit }}{\$ 3,600}$} & \multirow{2}{*}{$\frac{\text { Total Cost }}{\$ 3,600}$} \\
\hline Supervisory computer & & 1 & unit & & & \\
\hline $\begin{array}{l}\text { Measurement and Control } \\
\text { Software }\end{array}$ & $\begin{array}{l}\text { Capable of PID control } \\
\text { Animated display } \\
\text { Comprehensive math } \\
\text { calculation }\end{array}$ & 1 & & Labtech or CIMPAC & $\$ 6,000$ & $\$ 6,000$ \\
\hline Variable voltage transformer & 3KVA capacity & 3 & units & & $\$ 720$ & $\$ 2,160$ \\
\hline \multicolumn{7}{|l|}{ Psychometric Box } \\
\hline RTD temperature sensor & 4" pt $100 \mathrm{ohm}$ & 8 & units & & $\$ 270$ & $\$ 2,160$ \\
\hline $\begin{array}{l}\text { Standard mercury } \\
\text { thermometer }\end{array}$ & $\begin{array}{l}\text { 0-50 C range @ } 0.1 \mathrm{C} \text { max. } \\
\text { graduation }\end{array}$ & 4 & units & L\&N & $\$ 480$ & $\$ 1,920$ \\
\hline Blower and motor assembly & $\begin{array}{l}10 \text { cu m capacity } \\
0.25 \text { HP motor }\end{array}$ & 1 & & & $\$ 180$ & $\$ 180$ \\
\hline Air sampling tube & Stainless steel (2" diameter) & 2 & sets & & $\$ 480$ & $\$ 960$ \\
\hline \multicolumn{7}{|l|}{ Indoor Room Reconditioning Equipment } \\
\hline Recirculating blower & 80 cu m capacity & 1 & unit & & $\$ 1,200$ & $\$ 1,200$ \\
\hline Driver motor & 1.5 HP capacity & 1 & unit & & $\$ 420$ & $\$ 420$ \\
\hline Air heaters & 8-2 kW capacity & 1 & unit & & $\$ 1,800$ & $\$ 1,800$ \\
\hline Vaporizer box & $\begin{array}{l}4-2 \mathrm{~kW} \text { heater capacity } \\
8 \text { liter water reservoir }\end{array}$ & 1 & unit & & $\$ 960$ & $\$ 960$ \\
\hline Duct assembly & & 1 & unit & & $\$ 3,600$ & $\$ 3,600$ \\
\hline
\end{tabular}




\begin{tabular}{|c|c|c|c|c|c|c|}
\hline Instruments & Specifications & \multicolumn{2}{|c|}{ Quantity } & Brand & Cost/Unit & Instruments \\
\hline \multicolumn{7}{|c|}{ Outdoor Room Reconditioning Equipment } \\
\hline Water chiller unit & $\begin{array}{l}6 \text { ton refrigerating capacity } \\
\text { compressor unloading capability } \\
\text { water temperature control } \\
\text { stability: } 0.1 \text { degree }\end{array}$ & 1 & unit & & $\$ 24,000$ & $\$ 24,000$ \\
\hline Recirculating blower & 80 cu m capacity & 1 & unit & & $\$ 1,200$ & $\$ 1,200$ \\
\hline Driver motor & 1.5 HP capacity & 1 & unit & & $\$ 402$ & $\$ 402$ \\
\hline Vaporizer box & $\begin{array}{l}4-2 \mathrm{~kW} \text { capacity } \\
8 \text { liter water reservoir capacity }\end{array}$ & 1 & unit & & $\$ 960$ & $\$ 960$ \\
\hline $\begin{array}{l}\text { Chilled water circulating } \\
\text { pump }\end{array}$ & 100 lpm capacity & 1 & unit & & $\$ 840$ & $\$ 840$ \\
\hline Cooling coils & 5 ton cooling capacity & 1 & unit & & $\$ 3,600$ & $\$ 3,600$ \\
\hline Duct assembly & & 1 & unit & & $\$ 3,600$ & $\$ 3,600$ \\
\hline \multicolumn{7}{|l|}{ Pressure Equalizing Device } \\
\hline Pressure nozzles & $\begin{array}{l}2-75 \mathrm{~mm} \\
2-50 \mathrm{~mm}\end{array}$ & 1 & unit & & $\$ 690$ & $\$ 960$ \\
\hline Measurement box & $300 \mathrm{~mm} \mathrm{X} 400 \mathrm{~mm}$ & 2 & units & & $\$ 720$ & $\$ 1,440$ \\
\hline Blower and motor & 20 cu m capacity & 2 & units & & $\$ 1,080$ & $\$ 2,160$ \\
\hline \multicolumn{7}{|l|}{ Test Chamber } \\
\hline & $\begin{array}{l}75 \mathrm{~mm} \text { thick bonded } \\
\text { polystyrene; } 3 \mathrm{~m} \mathrm{~W} \mathrm{X} 2.4 \mathrm{~m} \mathrm{H} \\
\text { X } 3.7 \mathrm{~m} \mathrm{D} \text {; air and vapor sealed }\end{array}$ & 1 & unit & Bondor & $\$ 18,000$ & $\$ 18,000$ \\
\hline
\end{tabular}




\begin{tabular}{|l|l|l|l|l|l|}
\hline Instruments & Specifications & Quantity & Brand & Cost/Unit & Instruments \\
\hline \multicolumn{2}{|l|}{ Automatic Voltage Supply Regulator } \\
\hline
\end{tabular}

\section{Notes:}

- In Australia and New Zealand only the calorimeter room method is acceptable for energy labeling.

- $\quad$ Equipment above mostly from Taiwan and are actual costs for instruments received by the Philippine department of Energy Fuels and Appliance Testing Laboratory from 1990 to 1992.

- Table does not include any duty costs, nor engineering and construction costs. 
- personal computer

Training Cost

- $\quad$ Cost shown is for 10 days training by ITS (typical for A/C training)

- $\quad$ Visit to other test laboratory

- Consultant time

- Visits to training facilities or other labs. Or hire consultants to help with commissioning of the facility. Examples of existing test facilities listed below:

1. ETL

2. Japan Ref and Air Conditioner Industry Association (JRAIA)

3. DOE-Fuels and Appliance Testing Laboratory, Philippines.

Accreditation Costs

Test of air conditioner at another test laboratory for comparison

Standard Purchase

Facility

- Depends on where facility will be sited. Possibilities include CEB central garage. Will need to build a climate controlled building on an existing slab. SLSI does not currently have the space. Another possibility is to build a new facility at the CEB training center.

- $\quad$ Storage space before and after testing will need to be made available.

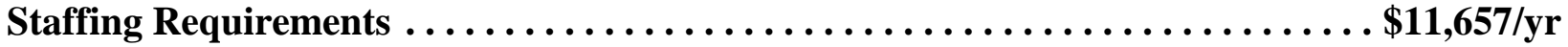

- (4) test technicians $(3 \times 6,000)$

- (2) engineer/supervisor $(2 \times 10,000)$

- $\quad$ (1) laboratory helper for the test preparation and setup $(1 \times 3,000)$

Operation Costs

- Calibration \& maintenance of instruments

- $\quad$ Electricity cost to condition test room

Calibration Services

TOTAL COSTS

- $\quad$ Start Up

- $\quad$ Recurring 


\section{Testing Capabilities}

(1) air conditioner tested at a time

(1) test per day

\section{Discussion}

Several approaches to establishing a test laboratory. Build from ground up or buy a pre-packaged test laboratory (turn-key) construction. Two U.S. companies offer complete systems and set-up of air conditioning test laboratories, ITS and TESCOR. Estimates from these sources are shown below.

\section{ITS Assessment of Equipment and Facility Costs}

(Turn-key test facility generalized from a Thailand project)

The typical units to be tested and certified in a Certification Program are Single Package and Split System Room Air Conditioners. A typical unit would be 230 volts, 50 Hz, 1 phase, although three phase units could be included. The size range would be 5,000 Btuh to 60,000 Btuh.

\section{Proposed Capabilities}

A test facility that performs to the requirements of ISO 5151 or equivalent standard is needed to correctly carry out the testing for a suitable certification program. This facility can be a balanced ambient calorimeter, a calibrated calorimeter, or a psychometric test facility. The capacity range required is from $5,000 \mathrm{Btu} / \mathrm{h}$ to $60,000 \mathrm{Btu} / \mathrm{h}$. Test samples may be either single package or split type.

\section{Equipment}

A facility of 250 square meters would be needed accommodate a test room, storage of test samples, and office space.

\section{Staffing Requirements}

Minimum staffing requirements for one test facility capable of performing 150 tests per year are as follows:

- (1) Department Manager

- (1) Department Secretary

- $\quad$ (1) Test Engineer

- (3) Test Engineering Technicians

Department Manager and Department Secretary may be shared when multiple facilities are specified. Possibly across different product test areas as well. To a lesser extent, technicians can be shared within the same product test area. Particularly when more then one similar highly automated test facility exists.

\section{Cost}

Total cost for one complete test facility is estimated at US $\$ 750,000$. 


\section{Other}

Other components needed to establish a certification program include a set of testing procedures, usually established by the testing laboratory or certification organization and an Operational Manual for the program established by the certification organization. The ISO Standards generally used for this product category are very complete in describing test methods; they will go a long way in helping to develop testing procedures. One observation that can be brought up here, is that presently manufacturers are allowed to set up the unit in the test room. This practice will slow down the total operation and should not be allowed once the program is fully implemented. This will also eliminate any influence the manufacturer could have on the performance of his units. This issue is an example of what would be covered in an Operational Manual. Test technicians should have the knowledge and ability to properly set up and adjust a test unit, regardless of the unit type or manufacturer.

TESCOR (Turn-key quote from U.S. Company)

A U.S. company that provides various levels of turn-key testing facilities for testing air conditioners. Full technical proposals are available upon request.

- $\quad$ Balanced Ambient Calorimeter, fully automated: $\$ 450,00 \pm 10 \%$

- $\quad$ Psychometric Test Facility, fully automated: $\$ 400,000 \pm 10 \%$

- $\quad$ For shipment to Asia by $40 \mathrm{ft}$. containers, add $\$ 20,000$ for each facility

- $\quad$ Field installation, supervision only, with one Tescor field technician and 5-6 buyer supplied trades men would run approximately $\$ 30,000$. Full installation with a Tescor crew of 4-5 people will be in the $\$ 70-\$ 80,000$ range. The project cycle from time of contract award to final field installation runs about 12 months.

- $\quad$ Costs are adjusted based on actual specifications. For example, a room built using aluminum would be less expensive than one built from stainless steel. 


\subsection{ELECTRIC MOTORS}

\section{Introduction}

According to Sri Lanka import data, motors are primarily imported from Hong Kong (76\%), Singapore (13\%) and China (10\%). From the APEC Workshop on setting up a testing laboratory we know that countries with motor standards include the U.S.A., Thailand and Mexico.

Countries with motor testing laboratories include Mexico and the U.S. See www.conae.gob.mx. ITS in the U.S. is also authorized by the Standards Council of Canada (SCC) as an accredited certification organization that administers an energy-performance verification program for motors. Also accredited and certified by SCC are CSA International (CSA) and Underwriters Laboratories Incorporated (ULI).

Motor efficiency testing protocols differ around the world, and their application on any given motor can lead to significantly different efficiency values. Many countries with no domestic motor manufacturing capacity import motors from a variety of countries using different testing procedures. Test procedures include the International Electrotechnical Commission protocols (IEC 34-2), the National Electrical Manufacturers Association (NEMA) protocols which conform to Institute of Electrical and Electronic Engineers protocols (IEEE 112), the Japan Industrial Standards (JEC-37) and other protocols. ${ }^{5}$

The above mentioned motor efficiency testing protocols lead to different efficiency values due to the way in which stray load losses are evaluated. Whereas in North America the NEMA standard provides for direct measurement of the motor efficiency, in other parts of the world indirect measurement methods are used. This requires the measurement of the motor losses, which is a fairly accurate procedure with the exception of the measurement of the stray load losses. With the NEMA standard the total losses are measured and it is possible to infer stray losses. ${ }^{6}$ IEC is in the process of evaluating a new standard that accounts for all of the losses, as in the North American standard.

\section{Three Alternative Assessments for a Motor Testing Facility}

\section{Alternative 1: ITS Assessment for Thailand project generalized}

\section{Forward}

Motors are generally one of the largest overall consumers of electrical energy based on the wide range of use and quantities installed in the residential and commercial community. Given this, it would seem reasonable to put motors high on the list of products to be pushed into an energy efficiency certification program.

\section{Proposed Capabilities}

Actual horsepower output range to include in a certification should be considered prior to any major investments. Cost and benefit should be reviewed in detail. Based on data available the following should be considered: 
- $\quad$ Majority of motors used

- $\quad$ Horsepower, Voltage, Frequency, Phase and type of motors

- $\quad$ Test equipment cost tends to increase dramatically above 1 horsepower

- Efficiencies of low lower < 10 horsepower motors generally are below $85 \%$

- $\quad$ Fractional horsepower test procedures should be well defined

\section{Equipment}

Required laboratory space and support equipment is minimal for one test stand. (20) Square meters would be sufficient.

Instruments required as part of test stand:

- $\quad$ Regulated AC power supply

- $\quad$ Power analyzer

- Dynamometer controller

- Dynamometer loading module

- $\quad$ Temperature measuring equipment

- $\quad$ Computer control/measurement system

- Software

- Enclosure

- $\quad$ Motor test platform

\section{Staffing Requirements}

Minimum staffing requirements for one test stand capable of performing from 100 - 200 tests per year per test stand are as follows:

- Department Manager

- Department Secretary

- (2) Test Engineering Technicians

\section{Cost}

Total cost for one complete motor test apparatus for motors up to 1 horsepower is estimated at US $\$ 35,000$ - $\$ 75,000$, estimated cost for $1-10$ horsepower is $\$ 75,000$ - $\$ 125,000$.

\section{Alternative 2: Motor Test Facility for Thailand $^{7}$}

The basic requirements for directly measuring motor efficiency per the IEEE 112B (three-phase) and 114B (single-phase) consist of input power measurements using electrical instruments and output power measurements using a mechanical device known as a dynamometer. In addition, there are peripheral devices and techniques needed to ensure accuracy, repeatability and ease of testing. We recommend higher standards for measurement accuracy than allowed by IEEE; the overall accuracy of the tests should be better than $+/-0.4$ percent; the overall repeatability of the testing should be better than $+/-0.3$ percentage points. 
Three requirements for the facility are assumed to be available and are not included in the following cost estimate. One is the necessary space within a building, about 25 square meters per test station up to 7 stations, plus office and storage space. Another is the availability of reliable electrical input power to the test equipment; the quantity of power is determined by the size and number of motors under test, but potentially as much as $400 \mathrm{kVA}$ of three-phase power. Finally, the availability of cooling water (preferably from a cooling tower) is needed for the larger dynamometers; up to 50 cubic meters per hour of water at 5 degrees $\mathrm{C}$ temperature difference may be required.

The following components are recommended for each test station:

- Input Power Conditioning:

- Isolation transformer

- Variable transformer(s) to adjust voltage to each phase

- $\quad$ Input Power Measurements:

- Current transformers (separate for current and power)

- Voltage, Current, Power, and VAR transducers

- $\quad$ Output Power Measurements:

- $\quad$ Dynamometer (power absorption unit with torque arm and load cell)

- Tachometer to measure speed.

- Control, Recording, and Reporting Equipment:

- Computer, IBM PC AT or equivalent

- Analog to digital interface card for electrical input and mechanical output signals

- Software for control, logging data, and issuing reports

- $\quad$ Mounting and Coupling Equipment:

- Adjustable mounting base to accommodate all motor sizes to be tested at that station

- Couplings to adapt all motor shafts to dynamometer

- Alignment tools to ensure shaft alignment

Test stations with the following capabilities are recommended. Note that several of the stations can switch size ranges or number phases, in order to maintain as much flexibility as possible. The estimated cost is listed based on Flora, Farlow, and Geisberger (1992). 
Table 6.14 Motor Test Facility Cost - Thailand

\begin{tabular}{|c|l|c|}
\hline Number of Stations & Type of Station & Cost of Station(s) kB \\
\hline 1 & 1-phase, fractional to 2 hp & 750 \\
\hline 2 & 1 or 3-phase, fractional to 2 hp & 2,500 \\
\hline 1 & 1-phase, 2 to 10 hp & 1,300 \\
\hline 1 & 1 or 3-phase, 2 to 10 hp & 1,800 \\
\hline 1 & 1-phase 10 to 20 hp; 3-phase, 10 to 100 hp & 3,800 \\
\hline 1 & $\begin{array}{l}\text { 3-phase 5 to 200 hp (w/interchangeable } \\
\text { dynamometers) }\end{array}$ & 5,000 \\
\hline
\end{tabular}

Total Cost $=15,000 \mathrm{kB}$

Costs are given in 1000's of Baht. Assuming a conversion rate of 1 U.S. $\$=25 B a h t$ in 1992, we get a total cost of U.S.\$600,000. Summing only the costs to $100 \mathrm{hp}$, we get a cost of US\$406,000.

No larger test station is recommended at this time. Motors over $200 \mathrm{hp}$ are few and their efficiencies are generally well specified by the purchaser and well measured by the manufacturer. The need to test larger motors should be reviewed. One alternative to having the capability to directly test large motors in the test facility is for the test facility personnel to observe and verify the accuracy of testing performed in the manufacturers' facilities.

\section{Facility Operation}

Each motor test takes about 6 to 12 hours, depending on the need to change couplings, mounts, electrical configurations, etc. If the facility operates its seven stations continuously for three shifts, 6 days per week, then about 6000 motors could be tested per year.

\section{Facility Design and Set-Up}

We recommend consultation with firms and laboratories who have experience in setting up test facilities in general and motor test facilities in particular. This includes ORTECH (see Geisberger), ETL, Industrial Electrotechnology Laboratory (see Farlow), LTEE, and Oregon State University. Their experience can avoid many potential pitfalls in the process, and they can provide related services such as operator training, software, and periodic calibration.

\section{References and Contacts (for Alternative 2)}

de Almeida, Anibal, University of Coimbra, Portugal, fax 351-39-35672,

ECCT Energy Conservation Center of Thailand

ETL Testing Laboratories

Cortland, New York 
USA

Farlow, Jeff, Industrial Electrotechnology Laboratory, North Carolina, 919-515-3941

Flora, Denise, North Carolina Alternative Energy Corporation, 919-361-8000

Geisberger, Paul, ORTECH International, Ontario CANADA, 416-822-4111

LTEE (Laboratory of Electrical Testing)

Shawinigan, Quebec

CANADA

Tel. 819-539-1400

Oregon State University

Corvallis, Oregon

USA

Tel. 503-737-3026

www.ece.orst.edu/ msrf/specs.html

(provides information on instrumentation and test setup)

\section{$\underline{\text { Alternate } \text { - Motor Test Facility for the Philippines }}{ }^{2}$}

\section{Motor Efficiency Testing}

The efficiency of electric motors can be either measured directly or indirectly. Direct methods are generally more accurate, but its use has not been widespread around the world due to the need to minimize the costs associated with setting up the testing laboratories. The direct methods (IEEE 112-B, CSA-390) are preferred. Indirect methods include:(IEC 34-2, JEC 37).

The ongoing revision of the IEC Standard makes appropriate that the new testing laboratory is prepared to make efficiency measurements in accordance both with direct and indirect methods.

\section{Design of Motor Test Facility Including Electrical Instrumentation/control}

\section{General requirements}

The testing facility will initially be used to measure the efficiency of general purpose $1 / 2-10$ hp alternating current (AC) motors. AC motors to be tested can be either single-phase or three phase. Supply voltage in the Philippines is 460 and 230 volts, $60 \mathrm{~Hz}$. The testing facility will be able to accommodate both NEMA and IEC (metric) frames. The most common motor speeds 3,600, 1,800 and 1,200 RPM, will be accommodated . Other speeds can be accommodated subject to the speed, power dissipation, and torque ratings of the dynamometer. In general, lower

\footnotetext{
${ }^{2}$ This section is excerpted from the publication: Design of a Motor Efficiency Testing Laboratory for the Department of Energy of the Philippines, Anibal de Almeida, 1998 
speed (less than 1200 RPM) motors should be able to be tested with the maximum torque provided by the dynamometer.

The instrument accuracy should comply not only with present IEC requirements, but also with foreseen requirements (1999 revision of IEC 34-2).

The facility will have the possibility to expand the testing range up to $50 \mathrm{hp}$, using the space provided by a second testing cell.

\section{Layout and Electrical Specifications}

Because motors are heavy, its operation may be noisy and produce some vibration, the motor testing facility should be located preferably at ground level, with easy access to bring in and move out the motors to be tested. The total space required for two testing cells, storage and support office space, is around 125 square meters. If space for future expansion is required, 150 square meters will allow the installation of a third testing cell. Because of the limited power level of the motors to be tested, there are no special foundation requirements.

\section{Storage and Handling}

The motors need to be moved from the laboratory receiving area to the storage area, then to the testing laboratory, then to the storage area and finally to the shipping area. There are two main options to handle the motors:

-Using a gantry crane able to lift and move heavy motors and other equipment. This option appears pertinent for handling large motors ( specially) above $100 \mathrm{hp}$

-Using an hydraulic jack mounted on wheels with a lifting capability of 2 tons. If only motors up to $50 \mathrm{hp}$ are going to be tested, this option should be implemented due to its reduced cost

The layout design should consider the following storage spaces, which can be implemented in two halves of the same room:

-A storage space for the incoming motors to be tested

-A storage space for the outgoing motors already tested

Both storage spaces should include the space where the motors are placed and the circulation areas for the lifting equipment. The area of these spaces will be strongly dependent upon the foreseen number of motors to be in sock at a given time. Assuming a total number of motors not exceeding 50 motors, a storage space of 50 square meters is recommended. This space assumes that no shelves are used, in order to minimize the possibility of accidents. The storage space needs no air conditioning, but humidity levels should be kept below condensation

\section{Motor Testing Cells}

It is recommend to have about 25 square meters for each testing cell. The testing cell is composed by: 
- A bench about 4 meters long and 1 meter wide, to mount the electrical and electronic testing equipment, as well as the computerized data acquisition and control system. Over the bench there may be shelf for keeping testing accessories.

- A space with limited access, protected from the surroundings with a thin mesh metal grid (part of the protection can be the outer wall), 5 meters long and 3 meters wide where the dynamometer and the motor to be tested are going to be located. In this space there will be also shelves for portable instruments, assembly tools, mounting plates, flange couplings and accessories.

\section{Office for the Laboratory Engineer}

This office will have a small library (technical books, journals, trade magazines, technical manuals of the laboratory instruments, motor catalogues), as well as the workspace for the laboratory engineer and his assistant (two desks with personal computers and a laser printer). The preparation of testing reports, and dealing with customers will be done in this office.

\section{Electrical Requirements}

Harmonic distortion can increase steeply the losses of electrical motors and therefore decrease the efficiency values of the motors being tested. The total harmonic distortion of the 3 phase supply should be under $1 \%$. One of the instruments specified (harmonic analyzer) will allow the monitoring of the power quality. If there are nearby factories with arc furnaces, large variable speed drives or other significant non-linear loads, power quality may be low. In this case, there may be a need to install harmonic filters to reduce harmonic distortion to under $1 \%$.

The voltages applied to the motors under test, as well as the voltage unbalance, should be kept under $1 \%$. Variations above this value can strongly influence the efficiency measurements. An automatic voltage regulator able to control individual phase voltages should be installed.

Assuming that the maximum motor load connected at any given time is $60 \mathrm{hp}$, and in order to avoid voltage sags each time a motor is started, the recommended transformer power is a minimum of $250 \mathrm{KVA}$, plus the power requirements for space conditioning and lighting. Dedicated cables should be used from the transformer to the dynamometers. The circuit breakers should be motor duty type and rated for $120 \%$ of the motor maximum steady state power.

The circuits to connect the testing instruments should also be mounted on dedicated cables and include protection against transients.

\section{Space conditioning of the testing laboratory}

In order to provide good stability and accuracy for the testing equipment it is desirable to keep the temperature in the range $23 \pm 5$ degrees $\mathrm{C}$. The humidity should be in the range 30 to $75 \%$ $\mathrm{RH}$ (non-condensing) 


\section{Cooling requirements for the dynamometers}

Cooling of the dynamometers can be carried by the following means:

- Air cooling, which can be carried typically up to $50 \mathrm{hp}$. This is the recommended solution specially for the small motor test cell (up to $10 \mathrm{hp}$ ). To prevent overheating of the test laboratory an air circulation conduct should be connected to the dynamometer to channel the waste heat to the outside of the building. Two air ducts -one incoming outside air, the other for the expelling the warm air- with a cross section of $30 \times 30 \mathrm{~cm}$ - should be located in the test cells. If there is one outside wall limiting the test cells, the openings can be made in that wall.

- Water cooling. Some dynamometer manufacturers require water cooling for medium and large units, using either a water tank with a heat exchanger, or continuous water flow. For a $50 \mathrm{hp}$ unit a continuous water flow of 20 liters per minute will suffice to cool the dynamometer, with a temperature change of less than a 30 degree Centigrade. If water is scarce at the test location, a tank with 1 cubic meter will allow almost one hour of continuous full load testing of a $50 \mathrm{hp}$ motor, again without exceeding the same temperature increase. Some dynamometer manufacturers provide a built-in water tank with their dynamometers.

\section{Data acquisition and control system}

The test facility will be controlled by a data acquisition and control system, which will be able to perform in an automated mode the efficiency and power factor test from no-load (or near condition due to minimum residual torque given by the dynamometer) to full-load. Inputs to the data acquisition system will include speed and torque (both provided by the dynamometer), operating temperatures (provided at least by 4 temperature sensors), currents, voltages, power factor, active power and reactive power (provided by a three-phase power analyzer). The control system will be programmed to change the load produced by the dynamometer. The software will generate automatically the efficiency and power factor curves as a function of the load

\section{Instrumentation accuracy requirements}

Table 6.15 shows the minimum accuracy requirements of the instruments used to test the motor efficiency. It can be seen that the requirements for IEEE 112-B are significantly stricter than for IEC 34-2. For this reason and taking into account the revision of IEC standard, the minimum accuracy requirements should be based on the requirements of IEEE 112-B. 
Table 6.15 Instrumentation Accuracy of Efficiency Testing Standards for Electric Motors

\begin{tabular}{|c|c|c|}
\hline Unit & IEC 34-2 & IEEE 112 (Method B) \\
\hline Power, $\mathrm{W}$ & $\pm 1,0 \%$ & $\pm 0,2 \%$ \\
\hline Current, I & $\pm 0,5 \%$ & $\pm 0,2 \%$ \\
\hline Voltage, $\mathrm{V}$ & $\pm 0,5 \%$ & $\pm 0,2 \%$ \\
\hline Frequency, $\mathrm{Hz}$ & $\pm 0,5 \%$ & $\pm 0,1 \% \mathrm{fN}$ \\
\hline Speed, $\mathrm{RPM}$ & \pm 2 & \pm 1 \\
\hline Torque, $\mathrm{N} \mathrm{m}$ & --- & $\pm 0,2 \%$ \\
\hline Ohms & $\pm 0,5 \%$ & $\pm 0,2 \%$ \\
\hline Temperature, ${ }^{\circ} \mathrm{C}$ & \pm 2 & \pm 1 \\
\hline
\end{tabular}

List of Equipment and Instruments (compiled by Anibal de Almeida)

The motor testing laboratory will have the following equipment and instruments for each test cell (minimum accuracy requirements are stated in Table 6.15):

\section{Dynamometer}

It must be emphasized that in order to take advantage of the accuracy requirements of the torque transducer, the torque range in the measurements should not exceed one order of magnitude (e.g. $1-10 \mathrm{hp}$ in the same speed range). Therefore choosing a dynamometer with a $10 \mathrm{hp}$ capability at 1800 RPM is suggested. Efficiency testing of $1 / 2$ and $3 / 4$ hp motors should be possible, even if with a reduced accuracy.

The dynamometer should include mounting adaptor plates for the different frame (both NEMA and IEC metric) sizes, as well as the flange adaptors for shaft coupling in the horsepower range $1 / 2-10 \mathrm{hp}$. NEMA frames to be tested range from frame 48 to $284 \mathrm{~T}$. IEC frames range from 71 to 160. Calibrating weights and arm should also be included.

The dynamometer should have the possibility of being remotely controlled to change the applied torque. It should also have available the speed and the torque as a digital output for a computer interface. The availability of easily readable displays is recommended.

\section{Three-Phase Power Analyzer}

The power analyzer samples the motor currents and the voltage waveforms and calculates the instantaneous power and power factor. This unit can be used both with single phase and three phase motors. Ideally it should be able to directly measure (without voltage transformers or current transformers) the power of 3-phase motors up to $10 \mathrm{hp}$, and of single phase motors up to $5 \mathrm{hp}$. The digital values of the currents, voltages, active power and the power factor should be available through a computer interface. Because there are moderately priced models in the market, the error in power measurement should be specified at $\pm 0,1 \%$ (twice more accurate than the minimum accuracy value in Table 6.15) .

\section{Data Acquisition and Control System}

This unit, probably based in a personal computer, has the possibility of reading (up to 10 times per second) the outputs of the dynamometer and of the power analyzer, as well as should have at 
least 4 inputs for temperature sensors. These sensors should also be included. The availability of 4 additional analog inputs is desirable. The unit should be supplied with data acquisition, automated dynamometer control and efficiency evaluation software. The generated output should include the graphs showing the variation of the efficiency and power factor as a function of the load.

\section{Portable Harmonic and Power Analyzer}

The portable harmonic analyzer will allow the monitoring of the power quality supplied to the testing laboratory. This instrument should be able to measure current and voltage distortion, both in terms of total harmonic distortion and individual harmonics up to the 31 st harmonic. This portable instrument should also have capabilities for measuring with $2 \%$ accuracy voltages, currents, power factor and power.

\section{Automatic Voltage Regulator}

The three-phase automatic voltage regulator will allow the voltage applied to the motor to be kept within $1 \%$ of the nominal value even if there are large voltage fluctuations of the supply voltage. The automatic voltage regulator should also compensate for differences in the phase voltages leading to a voltage unbalance of less than $1 \%$.

\section{Possible Suppliers}

\section{Dynamometer with Data Acquisition and Control System}

Although there are several dynamometer manufacturers on the market, most of them concentrate in medium and large power ranges, since their main market is the testing of internal combustion engines. With the information available, Magtrol seems to have the most suitable solution. However, The following companies deserve to be contacted:

\section{Magtrol, Inc.}

70 Gardenville Parkway

Buffalo, New York 14224

Phone:(716)668-5555

(800)828-7844

Fax:(716)668-8705

E-mail: magtrol@magtrol.com

Web site: http://www.magtrol.com

This company seems to be able to provide all the main items of equipment and instruments required for the test cell (Dynamometer HD-825, DSP6000 Controller, M-Test Software and the Power Analyzer 6550). A complete set of equipment costs in USA around US $\$ 45,000$. They also provide one day of free training. Additional days of training can be purchased for around US\$1100 per day.

\section{Roland Marine, Inc.}

90 Broad Street

New York, N.Y. 10004 
Phone:(212)269-1075

Telex:222197, 422634

Telefax:(212)269-1032/943-4346

This company represents in USA the German company Zollner, one of the largest manufacturers of dynamometers. The model A-20 is too small for the $1 / 2$ to $10 \mathrm{hp}$ power range, and the next model A-40 is too large. These models cost around US $\$ 35,000$ with the controller, but without the power analyzer. Their selection of dynamometers seems more appropriate for the 5-50 hp range (A-220 model), although they are introducing new units.

\section{Mustang Dynamometer}

2300 Pinnacle Parkway

Twinsburg Ohio 44087,USA

Tel: (330)-963-5400

Fax: (330)-425-3310

This company makes dynamometers with computer controller and testing software. The price for a complete unit with a $15 \mathrm{hp}$ capability at $1800 \mathrm{RPM}$, but without the power analyzer, is around US $\$ 20,000$.

\section{Power Test, Inc.}

N60 W14630 Kaul Avenue

P.O. Box 927

Menomonee Falls, Wisconsin 53052,USA

Phone:(414)252-4301

Fax:(414)252-4700

E-mail: info@pwrtst.com

Web site: http://www.pwrtst.com

This company makes water brake dynamometers more suitable for medium horsepower range, but they seem to have customization capabilities. Their dynamometers cost (Model 1901) around $\$ 23,000$ but the controller and data acquisition package cost an additional US\$34,000.

AW Dynamometer, Inc.

P.O. Box 528

Colfax, Illinois 61728, USA

Phone:(309)723-2021

Fax:(309)723-4951

This company supplies medium accuracy (Torque error of 1-2\%) portable units, which are suitable to make field measurements of motor efficiency. Model 5222 is able to test motors in the range $1.5-9 \mathrm{hp}$ at $1800 \mathrm{RPM}$ and costs around US $\$ 10,000$. The power analyzer is not included. This unit is only recommended if the FATL-DOE intends to carry out field audits.

\section{Schenck Pegasus Corporation}

2890 John R Road, Troy, MI 48083

Phone:(248)689-9000 Ext. 281 
Fax:(248)689-8578

AlanC@ schenckpegasuscorp.com

This company specializes in dynamometers for the automotive sector, although they claim to be able to produce customized solutions.

\section{Three-Phase Power Analyzer}

Two companies supply very similar instruments, which are suitable to measure with the required accuracy the electrical variables. The prices are also similar being in the range of US\$ $10-11,000$.

\section{Magtrol, Inc.}

70 Gardenville Parkway

Buffalo, New York 14224

Phone:(716)668-5555

$(800) 828-7844$

Fax:(716)668-8705

E-mail: magtrol@magtrol.com

Web site: http://www.magtrol.com

If the dynamometer is supplied by Magtrol, it is recommended to purchase the power analyzer Mode 6550 from them, in order to allow easier integration.

\section{Yokogawa Electrical Corporation}

9-32, Nakacho 2-Chome, Musahino-shi

Tokyo 180-0006, Japan

Tel: $+81-422-52-5535$

Fax: :+81-422-55-1202

They also have an office in USA

The model recommended is the Digital Power Meter WT 1030

\section{Portable Harmonic and Power Analyzer}

An instrument meeting the specifications mentioned in 3.4 is made by Fluke - the Fluke 41B Harmonic Analyzer, costing around US\$2000. More sophisticated harmonic analyzers are available at higher costs from Dranetz/BMI which can also perform power quality tests in terms of transients.

\section{Fluke Corporation}

P.O. Box 9090

Everett, WA 98206, USA

Tel: (206)-347-5500

Fax:(206)-356-5116

E-mail: fluke-info@tc.fluke.com 


\section{Dranetz/BMI}

1000 New Durham Road

Edison, NJ 08818-4019, USA

Tel: (732)-287-3680, or 1-800-DRANTEC,

Fax: (732)-248-1192

\section{Mechanical couplings}

It is desirable that the dynamometer comes with mechanical accessaries (e.g. mounting plates and flange couplings) to install general purpose motors. Accessories for mounting special purpose motors can be obtained through:

\section{Kaman Industrial Technologies \\ 1 Waterside Crossing \\ Windsor, CT 06095 \\ Phone:1-800-526-2626 \\ www.kaman-ind-tech.com}

\section{Automatic Voltage Regulator}

It is recommended that the 3-phase Automatic Voltage Regulator (AVR) is purchased with a power rating of at least $50 \mathrm{KVA}$, in order to allow overload tests of $50 \mathrm{hp}$ motors. Individual phase control to allow the regulator to compensate for unbalanced phase voltages should be included in the AVR specifications. Overall phase unbalance should be kept under + or $-1 \%$. The AVR should be able to compensate voltage fluctuations of $+10 \% /-15 \%$, and keep output voltage under + or $-1 \%$ of the desired value

\section{Hipotronics}

Route 22, P.O.Box 414

Brewster, NY 10509, USA

Tel: (914)-279-8091

Fax: (914)-279-2467

\section{Powerex Enterprise Co., Ltd.}

4Fl., No. 24, Lane 54, Chung Cheng Rd.

Hsin Tien City,

Taipei, Taiwan

Tel:886-2-2918-2437

:Fax:886-2-2918-5284

\section{Standard Test Procedures and Other Relevant Publications}

\section{National Electrical Manufacturers Association (NEMA)}

MG-1: Motors and Generators

This document provides guidelines and practical information on safety, testing, 
construction and operation of electric motors and generators.

MG-2: Safety Standard for Construction and Guide for Selection, Installation and Use of Electric Motors

$\$ 15$

This document sets design standards for specific motor and generator safety features, their proper selection, installation and use.

MG-3: Sound Level Prediction of Rotating Machinery

This document provides a method for estimating sound pressure levels of installed motors and generators.

MG-10: Energy Management Guide for Selection and Use of Polyphase Motors

This guide provides information on the proper selection, installation, operation, and maintenance of polyphase induction and synchronous motors.

MG-13: Frame Assignments for Alternating Current Integral-Horsepower Induction Motors

This standard assists users in selecting the proper frame size, horsepower and speed when selecting motors for specific applications.

Renewable Parts for Motors

This is a reference for the handling of maintenance problems common to motors and generators.

ICS 3.1 Safety Standards for Construction and Guide for Selection, Installation and Operation of ASD's

This document provides recommendations on the proper design, selection, installation, operation and testing of adjustable speed drive systems.

Available from:

National Electrical Manufacturers Association (NEMA)

Publications Distribution Center

P.O. Box 338

Annapolis Junction, MD 20701-0338, USA

Tel: (301)604-8002

Fax: (301)206-9789

Institute of Electrical and Electronics Engineers (IEEE)

IEEE 112: Standard Test Procedures for Polyphase Induction Motors and Generators $\$ 22.00$ 
This standard defines the proper testing and reporting of induction electric motor and generator performance. It is the basis for most induction motor efficiency testing in North America.

IEEE 739: Recommended Practice for Energy Conservation and Cost-Effective Planning in Industrial Facilities

$\$ 31.00$

This book provides guidelines for the correct design, operation and maintenance of industrial and commercial mechanical systems for cost effective energy conservation and efficiency.

Available from:

IEEE Customer Service

445 Hoes Lane, P.O. Box 1331

Piscataway, NJ 08855-1331, USA

Tel: (800)678-IEEE; (908) 981-1393

Fax: (908) 981-9667

\section{International Electrotechnical Commission (IEC)}

IEC 34-1: Rotating Electrical Machines Part 1: Ratings and Performance Price 66 Swiss Francs

IEC 34-2: Rotating Electrical Machines Part 2: Methods for Determining Losses and Efficiency of Rotating Electrical Machinery from Tests

Price 66 Swiss Francs

Available from:

International Electrotechnical Commission

Bureau Central de la Commission Electrotechnique Internationale

1, Rue Varembe

Geneva, Switzerland 


\subsection{CEILING FANS}

\section{Introduction}

Sri Lanka has some assembly/ manufacturing of ceiling fans. Hayleys Electronics Ltd. a local assembles fans from basic parts as well as imports fans. They wind motor from wires and laminations from Taiwan. Bearings are imported from Taiwan and blades are imported from India. They build a higher quality and more efficient ceiling fan by using silicon steel rather than carbon steel in the motor, using a choke type regulator and by using bearings rather than bushings. All locally built models use 70 Watts and have five different speeds. Blades range from 36 inches to 56 inches in diameter.

Imports of fans in general (there is no customs disaggregation into the different types of fans) come primarily from: India (23\%), China (20\%), Hong Kong (17\%), Singapore (12\%), Thailand $(11 \%)$, and Taiwan $(9 \%)$.

Table 6.16 Ceiling Fan Test Procedure Standards

\begin{tabular}{|l|l|l|}
\hline Standard & Comment & Country \\
\hline SLSI 814:Part.1 & $\begin{array}{l}\text { Seems to be similar to CSA procedure } \\
\text { based on IEC }\end{array}$ & Sri Lanka \\
\hline C814-96 & $\begin{array}{l}\text { The CSA document refers to the, } \\
\text { Performance and construction of electric } \\
\text { circulating fans and regulators. }\end{array}$ & Canada (CSA Standard) \\
\hline AMCA 230 & $\begin{array}{l}\text { based on measuring force produced by } \\
\text { the fan rather than measuring airflow }\end{array}$ & U.S. organization \\
\hline GB12021.9-89 & not in English & China \\
\hline IEC 879-1986 & $\begin{array}{l}\text { Sri Lankan standard seems to be based } \\
\text { on the IEC standard }\end{array}$ & \\
\hline
\end{tabular}

The Canadian (CSA) standard and the Sri Lanka standard seem to be almost identical. The Canadian standard specifies a hot wire anemometer air flow probe whereas the Sri Lanka standard specifies a rotating vane anemometer. The Canadian standard applies to describes the testing of ceiling fans only, whereas the Sri Lanka standard also applies to table and pedestal fans. The AMCA standard applies to circulator fans in general (axial type fans).

- $\quad$ Sri Lanka Standard 814: part 1: 1988 - Specification for Electric Fans and Regulators, Part 1 - Performance

- $\quad$ CAN/CSA C814-96 - Energy Performance of Ceiling Fans; National Standards of Canada (approved November 1998)

- BSR/AMCA Standard 230 - Laboratory Methods of Testing Air Circulator Fans for Rating 


\section{Discussion}

Sri Lanka does not currently have the facilities to test fans for energy efficiency. In the past, local manufacturers had the capability to measure air flow. The same test procedure and general setup is applicable to ceiling fans, table fans and pedestal type fans. For the SLSI, Canadian, and IEC standards air flow is measured by an anemometer. The AMCA standard indirectly calculated airflow based on measuring the force produced by a fan. Both methods are acceptable with the AMCA standard probably taking less time. In this, case the Canadian standard is recommended, as it is in conformance with IEC and existing Sri Lanka fan testing.

Table 6.17 Sri Lanka \& CSA Test Procedure Requirements for Ceiling Fans

\begin{tabular}{|c|c|c|c|}
\hline Instruments & Accuracy & Tolerance & Comments \\
\hline $\begin{array}{l}\text { Temperature } \\
\text { Measuring Device }\end{array}$ & $\begin{array}{l}+/-0.5 \mathrm{C} \\
(+/-1 \mathrm{~F})\end{array}$ & $\begin{array}{l}\text { The ambient temperature during the } \\
\text { testing of the fan shall be } 20+/-5 \mathrm{C} \text {. }\end{array}$ & $\begin{array}{l}\text { Prior to testing a fan shall be operated at } \\
\text { the test voltage and at full speed until } \\
\text { steady temperature conditions of the } \\
\text { motor become established. A period of } \\
2 \mathrm{~h} \text { is considered adequate for this } \\
\text { purpose. }\end{array}$ \\
\hline $\begin{array}{l}\text { Voltage, Ampere, } \\
\text { Power Factor, } \\
\text { Watt Measuring } \\
\text { Devices }\end{array}$ & $+/-0.5 \%$ & $\begin{array}{l}\text { The variation of voltage should not } \\
\text { exceed }+/-1 \% \text { of the test voltage during } \\
\text { the air performance test. The } \\
\text { arrangement of the apparatus shall } \\
\text { permit the anemometer to move in either } \\
\text { direction along both diagonals of the } \\
\text { test chamber in a horizontal plane } 1.5 \mathrm{~m} \\
+/-10 \mathrm{~mm} \text { below the plane of the fan } \\
\text { blades. }\end{array}$ & $\begin{array}{l}\text { The tests shall be conducted with the fan } \\
\text { connected to a supply circuit with a } \\
\text { voltage of } 120 \mathrm{~V} \text { for fans rated from } \\
105-125 \mathrm{~V} \text {; and } 240 \mathrm{~V} \text { for fans rated from } \\
208-250 \mathrm{~V} \text {. } \\
\text { [for Sri Lanka may want to run the test at } \\
50 \mathrm{~Hz} \text { and } 230 \text { volts] }\end{array}$ \\
\hline Time Interval & $+/-0.1 \%$ & & \\
\hline Air Flow & $+/-2 \%$ & & $\begin{array}{l}\text { The air delivery test chamber should } \\
\text { have a length of } 4.5 \mathrm{~m} \text {, width of } 4.5 \mathrm{~m} \text {, } \\
\text { and a height of } 3.0 \mathrm{~m} \text {. The test chamber } \\
\text { shall be surrounded with an external } \\
\text { screen with no top having a height of no } \\
\text { less than } 3 \mathrm{~m} \text {, and a length and width of } \\
\text { between } 6.5 \text { and } 7 \mathrm{~m} \text {. }\end{array}$ \\
\hline
\end{tabular}

Notes:

- $\quad$ Ambient temperature: $25 \mathrm{C} \pm 5 \mathrm{C}$

- The volume of air delivered is determined in a standard test room which is based on IEC Publication 879-1986;

- $\quad$ Air Flow Measurement in Sri Lanka Standard: Sri Lanka - rotating vane anemometer; internal dia. $>100 \mathrm{~mm}$

- $\quad$ Air Flow Measurement in CSA Standard: CSA - calibrated omni-directional hot wire anemometer

- $\quad$ To measure fan speed (rpm meter)-- stroboscope or optical pick-up and counter may be used 


\section{Testing Capacity}

- $\quad 2$ hours to achieve steady state temperature

- $\quad$ up to 14 annulus, at 4 points per annulus, therefore, up to 56 measurement points.

- $\quad$ measure at each point for 3 to 10 minutes. (If at 10 minutes each, test can take 9.3 hours.)

- $\quad$ readings should be average of 2 second samples by an anemometer. See standard for additional details.

- $\quad$ all measurements at full speed. Measurements at other speed are optional but may be considered to determine actual energy use in practice.

- $\quad$ total test time may vary, but expect no more than one fan every second day.

Table 6.18 Instruments \& Equipment for Testing Ceiling Fans

\begin{tabular}{|c|c|c|c|}
\hline Instrument & Brand \& Model\# & Specifications & Price \\
\hline Thermocouple wire & Omega TT-T-24SLE & 24 AWG type $T$ wire & $\$ 375$ \\
\hline Thermocouple meter & Omega MDSS41-TC & & $\$ 820$ \\
\hline $\begin{array}{l}\text { Digital VAW meter } \\
\text { (true RMS meter) } \\
\text { Include PF measurement }\end{array}$ & $\begin{array}{l}\text { Yokogawa } \\
\text { model WT130 }\end{array}$ & accuracy $0.25 \%$ of reading & $\$ 4,740$ \\
\hline $\begin{array}{l}\text { Anemometer - omni } \\
\text { directional, hot wire }\end{array}$ & $T S I$ & $\pm 1.5 \%$ of full scale & $\$ 899$ \\
\hline $\begin{array}{l}\text { rotating vane anemometer } \\
\text { (Sri Lanka standard) }\end{array}$ & $\begin{array}{l}\text { Davis Instruments } \\
\text { DVA 30VT, }\end{array}$ & $\begin{array}{l}\text { w/inch head; calibrated accuracy to } \\
1 \% \text { FSD; } .25 \text { to } 30 \mathrm{~m} / \mathrm{s}\end{array}$ & $\$ 1084$ \\
\hline tachometer -- rpm meter & $\begin{array}{l}\text { Davis Instruments: } \\
\text { SM78900 \& } \\
\text { SM78904 probe }\end{array}$ & & $\begin{array}{l}\$ 695+ \\
\$ 195\end{array}$ \\
\hline
\end{tabular}

Notes:

- $\quad$ Items in italic are alternate equipment to replace the item above it.

- $\quad$ Possible to automate - this estimate is for manual data acquisition

Equipment \& Instrument Costs $\ldots \ldots \ldots \ldots \ldots \ldots \ldots \ldots \ldots \ldots \ldots \ldots \ldots \ldots \ldots \ldots \ldots \ldots \ldots$

Test Room $\ldots \ldots \ldots \ldots \ldots \ldots \ldots \ldots \ldots \ldots \ldots \ldots \ldots \ldots \ldots \ldots \ldots \ldots \ldots \ldots \ldots \ldots \ldots \ldots \ldots \ldots, 0 \ldots$

\section{Requirements}

- $\quad$ Ceiling height of at least $4 \mathrm{~m}$

- Ambient temperature: $25 \pm 10^{\circ} \mathrm{C}$; need to condition room outside of chamber screen.

- $\quad$ Room in which the test chamber and outer screen are erected shall be suitably protected from air moving at more than $0.25 \mathrm{~m} / \mathrm{s}$

- $\quad$ Minimum size of room approximately $10 \mathrm{~m}$ by $10 \mathrm{~m}$

- $\quad$ Cost of air conditioning system and duct work (package or mini-split system) 
Test Chamber

\section{Requirements}

- $\quad$ custom build per standard

- $\quad$ chamber dimensions; length of $4.5 \mathrm{~m}$, width of $4.5 \mathrm{~m}$, height of $3.0 \mathrm{~m}$

- $\quad$ external screen without top;

height of $3 \mathrm{~m}$, length and width of between 6.5 and $7 \mathrm{~m}$

- $\quad$ cost of material and labor to build test chamber and screen: estimate $\$ 5000$ (local construction estimate needed)

- $\quad$ there shall be no heating or cooling apparatus anywhere in the system

Support equipment

- Personal Computer to write reports and keep records and do data reduction

Training costs

- $\quad$ travel to existing test facility

- $\quad$ or hire consultant to provide training on site

Accreditation

- Initial cost to get laboratory accredited (in addition yearly site inspections may be required to maintain accreditation)

Standard Purchase

Costs to buy standards and update test standards

Facility $\$ 20,000$

Discussion of Land \& Building for Test Facility

Possible locations for this test facility include the CEB training center and or main garage should this space become available after restructuring. In each case climate control is needed. SLSI does not currently have the room for test set-ups requiring this amount of space. The CEB central garage facility would need to have a climate controlled building built on an existing foundation. Some space is required to store fans to be tested before and after tests have been completed.

Staffing Requirements

- 2 technicians to set up fans and run test

- $\quad$ engineer to write-reports and deal with customers

Operating costs

- $\quad$ electricity costs

- $\quad$ costs to maintain temperature controlled room (air conditioning repair and maintenance)

Calibration Services

- costs to maintain and calibrate estimated to be $10 \%$ of equipment cost

- calibrate anemometer and watt-hour meter twice a year 


\section{TOTAL COST}

- $\quad$ Start Up Costs $\ldots \ldots \ldots \ldots \ldots \ldots \ldots \ldots \ldots \ldots \ldots \ldots \ldots \ldots \ldots \ldots \ldots \ldots \ldots \ldots \ldots \ldots \ldots \ldots \ldots, 110$

- $\quad$ Recurring Costs $\ldots \ldots \ldots \ldots \ldots \ldots \ldots \ldots \ldots \ldots \ldots \ldots \ldots \ldots \ldots \ldots \ldots \ldots \ldots, \ldots \ldots, 8, \ldots \ldots 7$

\section{Additional Reference Material}

Shaded pole motors used by conventional ceiling fans in the U.S. are very inefficient. Useful motor shaft output of only $12.8 \%$ at high speed and $2.6 \%$ at low speed (Oregon State University) ref. Development of a High Efficiency Ceiling Fan; FSEC-CR-1059-99; Parker et. al.

URL: http://www.fsec.ucf.edu/ bdac/ps/CR1059/CR1059.html 


\subsection{TELEVISIONS}

\section{Introduction}

Sri Lanka has a high saturation of televisions with most of these having remote controls. A typical television is $20 \mathrm{inch}, 75$ watts, 230 volts, $32 \mathrm{~mA}$. Sizes range for 14 inch to $20 \mathrm{inch}$. Sri Lanka no longer has a domestic television manufacturer. Most televisions are imported from: Singapore $(60 \%)$ and South Korea $(16 \%)$. APEC countries having television standards or labels include: China, Hong Kong, Malaysia, Philippines.

\section{Test Procedure Standards}

Task 2 of the report suggested limiting the standby losses to 1 watt would be an effective way to reduce the power consumption of televisions. Currently there is much activity and effort put into this issue. This would be a relatively simple test -- turn off the TV and measure the power consumption with a true RMS watt meter. The current U.S. DOE test procedure includes a standby energy use measurement. Measuring energy efficiency with the television in operation requires a more elaborate procedure.

Table 6.19 Television Test Procedure Standards

\begin{tabular}{|l|l|l|}
\hline Standard & Comment & Country \\
\hline China standard & not yet in English & China \\
\hline JIS C 6101-88 & $\begin{array}{l}\text { for comparing and evaluating performance - not specific to } \\
\text { energy efficiency }\end{array}$ & Japan \\
\hline GOST 18198-89 & not yet in English; on mode consumption only & Russia \\
\hline $\begin{array}{l}\text { CFR Title10 Part 430 } \\
\text { Subpart B, App. H }\end{array}$ & $\begin{array}{l}\text { Energy Star label if 3W or less in standby mode (power is } \\
\text { switched off) }\end{array}$ & USA \\
\hline SLS 694 & $\begin{array}{l}\text { Sri Lanka standard for measurement of testing television } \\
\text { receivers - do not have copy of this standard, so not know } \\
\text { if it includes efficiency testing but perhaps power } \\
\text { consumption is an adequate test. Measures electrical, } \\
\text { acoustical and optical properties }\end{array}$ & Sri Lanka \\
\hline
\end{tabular}

If the U.S. DOE standard is adopted, modifications needed include specifying the voltage to be $230 \mathrm{v}$ rather then $120 \mathrm{v}$ and specifying the television signal protocol to that used in Sri Lanka, e.g., NTSC, PAL or other. 
Table 6.20 U.S. DOE Test Procedure Instrumentation - Televisions

\begin{tabular}{|c|c|c|c|}
\hline Instruments & Accuracy & Tolerance & Comments \\
\hline $\begin{array}{l}\text { Signal } \\
\text { generator }\end{array}$ & $+/-3 \mathrm{~dB}$ & & $\begin{array}{l}\text { Capable of producing radio frequency (RF) television test } \\
\text { signals, at a convenient very high frequency channel, } \\
\text { modulated with (A) Standard White Pattern RF signal } \\
\text { modulated to } 87 \% \text { with a } 100 \text { IRE-unit flat field or (B) } \\
\text { Standard Black Pattern signal modulated to } 87 \% \text { with a } 0 \\
\text { IRE-unit flat field. Supplied by source whose impedance } \\
\text { equals the design antenna impedance of the TV set under } \\
\text { test, shall be adjusted to a level of } 70 \text { decibels (dB). }\end{array}$ \\
\hline $\begin{array}{l}\text { Regulated } \\
\text { power source }\end{array}$ & & $+/-1.2$ volts & $\begin{array}{l}\text { Capable of supplying } 120 \text { volts of alternating current } \\
\text { [can use auto-transformer or regulated AC power supply] }\end{array}$ \\
\hline Voltmeter & & & to insure tolerance \pm 1.2 volts \\
\hline Watt meter & $\begin{array}{l}\text { within } 1 \% \text { of the } \\
\text { full scale value } \\
\text { [e.g., } 1 \% \text { of } 50 \mathrm{~W} \\
=0.5 \text { Watts] }\end{array}$ & & $\begin{array}{l}\text { Capable of measuring the average power consumption of } \\
\text { the TV set under test. All measurements shall be made on } \\
\text { the upper half of the scale. [assume range of 50-300 } \\
\text { Watts] }\end{array}$ \\
\hline
\end{tabular}

Note: Modifications required to the U.S. DOE standard to meet Sri Lanka's needs:

- $\quad$ Sri Lanka may not be on the NTSC signal standard. Europe uses the PAL standard.

- $\quad$ Power supply would need to be capable of supplying 230 volts of $50 \mathrm{~Hz}$ alternating current.

Table 6.21 JIS Test Procedure Requirements - Televisions

\begin{tabular}{|l|l|l|l|}
\hline Instruments & Accuracy & Tolerance & Comments \\
\hline Temperature & & $\begin{array}{l}\text { Reference temperature shall be 20C } \\
+/-2 \mathrm{C} \text { and the reference humidity shall } \\
\text { be 65\% }\end{array}$ & \\
\hline Voltage \& frequency & $\begin{array}{l}\text { The voltage regulation and frequency } \\
\text { regulation of the power supply shall not } \\
\text { be more than }+/-2 \%, \text { and the harmonic } \\
\text { content of the power supply shall not } \\
\text { exceed 5\%. }\end{array}$ & \\
\hline
\end{tabular}

Table 6.22 Equipment based on U.S. DOE Television Standard

\begin{tabular}{|l|l|l|l|}
\hline Instrument & Brand & Specification & Price (approximate) \\
\hline Signal Generator & Tektronics SPG22 & & $\mathbf{\$ 4 , 6 0 0}$ \\
\hline $\begin{array}{l}\text { Regulated power } \\
\text { source }\end{array}$ & Stabiline PPCX52800 & $\pm 5 \%$ & $\mathbf{\$ 5 3 5}$ \\
\hline Power meter V-A-W & $\begin{array}{l}\text { Yokogawa } \\
\text { Model WT130 }\end{array}$ & $\pm 0.25 \%$ of reading & $\mathbf{\$ 4 7 4 0}$ \\
\hline
\end{tabular}

Total Equipment Costs 


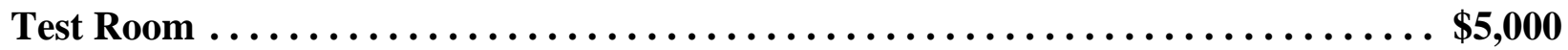

Support Equipment.$\ldots \ldots \ldots \ldots \ldots \ldots \ldots \ldots \ldots \ldots \ldots \ldots \ldots \ldots \ldots \ldots \ldots \ldots \ldots \ldots \ldots \ldots$

- personal computer

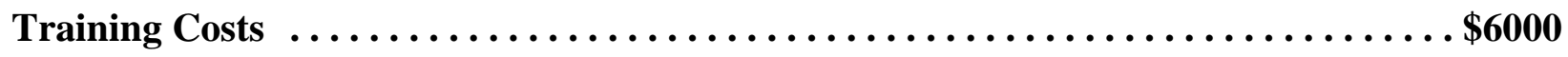

- $\quad$ Some training by equipment suppliers

- $\quad$ Consultant time

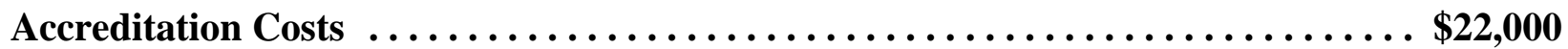

Standard Purchase $\ldots \ldots \ldots \ldots \ldots \ldots \ldots \ldots \ldots \ldots \ldots \ldots \ldots \ldots \ldots \ldots \ldots \ldots \ldots$

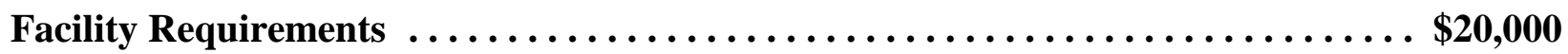

- A climate controlled room

- Workbench to place televisions on

- $\quad$ Some room to store televisions before and after testing

(Data recording is manual)

- $\quad$ Office space for record keeping, testing $\log$

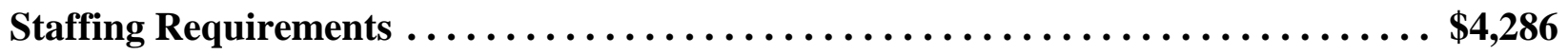

- $\quad$ one full time technician with electrical training

- $\quad$ one supervising engineer

- $\quad$ estimated test time 2 hours per television

Operation Costs $\ldots \ldots \ldots \ldots \ldots \ldots \ldots \ldots \ldots \ldots \ldots \ldots \ldots \ldots \ldots \ldots \ldots \ldots \ldots \ldots+\ldots \ldots \ldots$

- $\quad$ Maintenance of equipment

- $\quad$ Can verify results by testing same television at existing test laboratory

- Power to run televisions is minimal, cost of power to keep room climate controlled

Calibration Services ........................................ \$494

- $\quad$ assume $10 \%$ of equipment cost

TOTAL COSTS

- $\quad$ Start Up . . . . . . . . . . . . . . . . . . . . . . . . . . . . . . . \$66,075

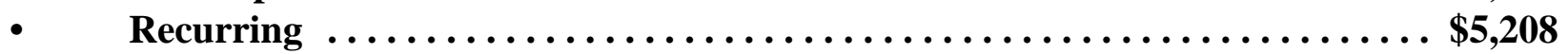

If only standby losses where measured for a standby labeling scheme whereby only an accurate watt meter was needed to measure low consumption of standby power [equip. cost approx. \$1000]. http://eetd.lbl.gov/standby

Standby power consumption only

- $\quad$ Start Up ..........................................\$\$ $\mathbf{\$ 3 5 , 0 0 0}$

- $\quad$ Recurring $\ldots \ldots \ldots \ldots \ldots \ldots \ldots \ldots \ldots \ldots \ldots \ldots \ldots \ldots \ldots \ldots \ldots \ldots \ldots \ldots \ldots \ldots \ldots \ldots, 764$ 


\subsection{PUMPS}

\section{Introduction}

CEB mentioned that pumps are estimated to use a significant amount of electricity and should be considered for testing. More detailed information would be needed to come up with a more accurate assessment of the possible energy savings. Data supplied by CEB showed pumps in the range of $0.1875 \mathrm{~kW}$ to $2.25 \mathrm{~kW}$ for single phase pumps, and $1.125 \mathrm{~kW}$ to $56.25 \mathrm{~kW}$ for 3-phase pumps. Among the pumps considered would be those to pump water for domestic households. A common pump size for this use is $3 / 4$ horsepower. A product data sheet provided by CEB listed domestic electrically powered pumps between 0.3 horsepower and 1.0 horsepower. These pumped from 760 to 1000 Igph. Output head ranged from 30 to $105 \mathrm{ft}$ at the rated flow. These pumps are single phase induction motors rated at $230 \mathrm{~V}$ and $50 \mathrm{~Hz}$.

Pumps are imported primarily from China (68\%) and India (26\%).

\section{Test Procedures}

The test procedure regarding pumps in Sri Lanka is: Sri Lanka Standard Code of Acceptance Tests for Centrifugal, Mixed Flow and Axil Pumps. This Sri Lanka standard is identical to ISO standard 2548, Centrifugal, mixed flow and axial pumps - Code for acceptance tests - Class C; 1973.

In this standard the measurement of pumping efficiency is discussed in section 6.5. It specifies that to determine the efficiency of a pumping unit "only the power input and output are measured, with the driver working under conditions specified in the contract". Some of the equipment required for testing is listed below.

Section 6.1: Measurement of flow rate

Several options are given:

- Weighing tank method

- $\quad$ Volumetric tank method

- $\quad$ Orifice plates, venturi tubes and nozzles

The smallest scale division shall be not greater than that corresponding to $1.5 \%$ of the flow.

Section 6.2.5: Instruments for pressure measurement

Several options are given:

- $\quad$ Liquid column manometers

- $\quad$ Bourdon dial gauges - scale graduations not more than 5\% of total pump head.

Section 6.4.2: Electric power measurements

- $\quad$ Measure with a wattmeter in accordance with IEC publication 51, Recommendation for indicating electrical measureing instruments and their accessories.

In basic terms the measurements necessary to determine efficiency are the watts into the pump 
motor (measured with a watt meter), the amount of flow (for example measured by pumping water into a large container that is weighted on a large scale, and the head produced by the pump measured with a manometer or pressure gauge.

\section{Table 6.23 Equipment Requirements}

\begin{tabular}{|c|}
\hline Equipment \\
\hline Power meter \\
\hline large container (x gallons) \\
\hline large scale \\
\hline manometer \\
\hline Bourden pressure gauge \\
\hline
\end{tabular}




\subsection{Sources of Information - Equipment Suppliers - Test Standards - Accreditation}

Reference Ballasts (variable linear reactors)

WPI Industrial Technology

40 Depot Street

Warner, $\mathrm{NH}$

Tel: 603-456-3111

fax: 603-456-3754

http://www.lightsearch.com/ads/catalog/wpi.html

NWL Transformers WPI Power Systems

312 Rising Sun Road Depot Street, PO Box 267

Bordentown, NJ, 08505 Warner, NH 03278

http://www.nwl.com/

\section{Anemometers}

http://www.tsi.com/

http://www.zelana.com/solomat/solomat.asp

\section{Power Meters}

Clarke-Hess http://www.clarke-hess.com/

220 West 19 Street,

New York, NY 10011

Tel:(212) 255-2940

Fax: (212) 691-8158

info@clarke-hess.com

Valhalla $\quad$ http://www.mill.net/valhalla/v2100.htm

Valhalla Scientific Inc.,

San Diego, CA 92121

Tel: $619-457-5576$

Fax: (619) 457-0127

valhalla@valhallasci.com

Rotek Instruments http://www.rotek.com/

390 Main Street,

Waltham, MA 02452 USA

Tel: (781) 899-4611

Fax: (781) 894-7273

sales@rotek.com 
Ohio Semetronics http://www.ohiosemitronics.com/

Ohio Semitronics, Inc.

4242 Reynolds Dr.

Hilliard, OH 43026

Tel: (800) 537-6732

Tel: (614) 777-1005

Fax: (614) 777-4511

Mfg.

Clarke-Hess

Valhalla

Rotek Instruments

Rotek Instruments

Ohio Semitronics $\underline{\text { Model }}$

2330

2100

$3030 \mathrm{~A}$

MSB 001A $\$ 6000$

W-010B

Counter

Panel Meter
$\$ 1095$

$\$ 4255$

Price

$\$ 3595$

$\$ 6000$

$\$ 410$

$\$ 75$

$\$ 190$
Specifications

0.6\%, 10A direct $\mathrm{W}-\mathrm{A}-\mathrm{V}-\mathrm{PF}-$ freq

$0.25 \%, 20 \mathrm{~A} \mathrm{~W}-\mathrm{A}-\mathrm{V}$

with clamp on probe, W-hr

$0.005 \%$ watts, to $5 \mathrm{Amps}$

add $\$ 200$ for 10 Amps

$0.5 \%$ f.s. accuracy, $10 \mathrm{~A}$ direct

pulse and analog output

\section{General Instrumentation}

http://www.electricnet.com/BuyersGuide/

\section{Data Acquisition}

http://vaneg1.ecs.umass.edu/Socratis/LabVIEW/

http://www.campbellsci.com/

\section{Test Facility Suppliers}

TESCOR

341 Ivyland Road

Warmister, PA 18974

http://www.tescor-inc.com/products.htm

Intertek Tesing Sevices NA Inc.

3933 US Route 11

Cortland, NY 13045

http://www.itsglobal.com/ 


\author{
Standards Organization \\ http://www.csa-international.org/ \\ http://www.wssn.net/WSSN/index.html \\ http://www.csa-international.org/english/home/index.htm \\ http://www.amca.org/publications/order.htm \\ http://www.iso.ch/ \\ http://www.proficiency.org/ \\ http://www.isr.gov.au/resources/apec-ewg/publications.html \\ http://webstore.ansi.org/default.asp \\ http://www.ansi.org/
}

\title{
Accreditation Organizations
}

http://ts.nist.gov NVLAP accreditation for testing lamps and ballasts

http://www.ilac.org/

http://www.A2LA.org/

http://www.microserve.net/ gdg/ - Fasor technical services

http://www.nata.asn.au/ NATA National Association of Testing Authorities Australia

http://www.proficiency.org/

http://www.a2la.org/pdfs/CALIBRAT799.pdf

http://www.a2la.org/a2la/CalibrationSource.htm cites other accreditation labs

http://www.scc.ca/certific/colist.html

\section{Calibration Services}

http://www.wylelabs.com/suppcal.htm

\section{Source to buy test procedures}

http://global.ihs.com/cgi-bin/

\section{Sources for Test Procedure Standards and Other Pertinent Literature}

ISO Development Manual 9 - Establishment and operation of a testing laboratory for a national standards body

Review of Energy Efficiency Test Standards and Regulations in APEC Member Economies, July 1999

Workshop on Setting-Up and Running an Energy Performance Testing Laboratory, July 1999

- $\quad$ Symposium on Domestic Refrigeration Appliances, APEC Project EWG 4/99T, March 2000; prepared by Lloyd Harrington of Energy Efficient Strategies, Melbourne, Australia

- $\quad$ Draft Indonesia Appliance Labeling Program Report and Recommendations, IIEC

- $\quad$ Proceedings: Workshop on Setting-up and Running an Energy Performance Testing Laboratory, Asia-Pacific Economic Cooperation, July 1999. 
- $\quad$ Review of Energy Efficiency Test Standards and Regulations in APEC Member Economies, July 1999

- Workshop on Setting-Up and Running an Energy Performance Testing Laboratory, July 1999

- Development of a High Efficiency Ceiling Fan; FSEC-CR-1059-99; Parker et. al.URL: http://www.fsec.ucf.edu/ bdac/ps/CR1059/CR1059.html

\section{Other Useful References}

Florida Solar Energy Center - Ceiling Fans

http://www.fsec.ucf.edu/

Oregon State University - motors

http://www.ece.orst.edu/ msrf/

\section{References}

1. Internal Intertek Testing Services Document, Chris Stone

2. Review of Energy Efficiency Test Standards and Regulations in APEC Member Economies, Asia-Pacific Economic Cooperation, July 1999

3. Workshop on Setting-Up and Running an Energy Performance Testing Laboratory, July 1999

4. Draft Indonesia Appliance Labeling Program Report and Recommendations, IIEC

5. Development of an Algorithm to Compare Motor Efficiency Testing Procedures, Anibal de Almeida

6. Ibid.

7. Excerpt from report on motor test facility for Thailand 


\section{RECOMMENDATIONS}

The analysis in Task 2 established the electricity savings potential for selected appliances in Sri Lanka. These appliances were chosen for analysis in part due to the availability of data on their energy consuming characteristics and use through a household survey recently conducted in Sri Lanka. The survey did not report on all energy consuming appliances and equipment in Sri Lanka, nor did it account for trends in ownership or characteristics. Discussions with appliance retailers indicated the belief that, while air-conditioning currently has a low saturation in households, it is expected to rise significantly as Sri Lanka's economy grows. This pattern has been observed in many surrounding economies in tropical Asia. Similarly, the DSM Branch of the CEB has collected data that indicates significant energy consumption of electric motors in all sectors of Sri Lanka. For these reasons, both air-conditioning and electric motors were added (along with lighting and refrigerators) to the priority list of 4 laboratory facilities and accompanying labeling program.

The benefit cost ratio estimate of 30 for the 6 product testing and labeling program described in Task 3 is unaffected by this reordering of priority products. This is because the analysis included the costs of all 6 products (air-conditioners, electric motors, lighting, refrigerators, ceiling fans, and televisions), while the benefits were calculated for the latter 4 products only. Thus, the benefit cost ratio would only increase with the inclusion of the benefits from the latter 2 products. ${ }^{1}$

With limited resources, the CEB may choose to start with a 4 lab program. Start-up and recurring annual costs for this program are shown in Table 7.1

Table 7.1 Costs for Four Lab Program

\begin{tabular}{|c|c|c|}
\hline & Start-up Costs & Recurring Costs \\
\hline Labeling Program Office & 70,000 & 35,829 \\
\hline International Consultation & 617,850 & \\
\hline Lighting Lab & 166,094 & 13,303 \\
\hline Refrigerator Lab & 184,320 & 12,111 \\
\hline Air-Conditioners Lab & 269,634 & 20,979 \\
\hline Electric Motors Lab & 301,200 & 23,626 \\
\hline Total 4 Lab Program Costs & $1,609,098$ & 105,848 \\
\hline
\end{tabular}

Ceiling fans and televisions are combined with the products above to form the 6 lab program. The start-up and annual recurring costs for this larger program are depicted in Table 7.2.

\footnotetext{
${ }^{1}$ The benefit cost ratio of the 4 lab program only was not calculated due to the lack of data for estimating the savings potential and benefits for air-conditioning and electric motors testing and labeling.
} 
Table 7.2 Costs for Six Lab Program

\begin{tabular}{|c|c|c|}
\hline & Start-up Costs & Recurring Costs \\
\hline Labeling Program Office & 70,000 & 35,829 \\
\hline International Consultation & 861,502 & \\
\hline Lighting Lab & 166,094 & 13,303 \\
\hline Refrigerator Lab & 184,320 & 12,111 \\
\hline Air-Conditioners Lab & 269,634 & 20,979 \\
\hline Electric Motors Lab & 301,200 & 23,626 \\
\hline Ceiling Fan Lab & 69,110 & 6,807 \\
\hline Television & 66,075 & 5,208 \\
\hline Total 6 Lab Program Costs & $1,987,935$ & 117,863 \\
\hline
\end{tabular}

